Historic, Archive Document

Do not assume content reflects current scientific knowledge, policies, or practices. 



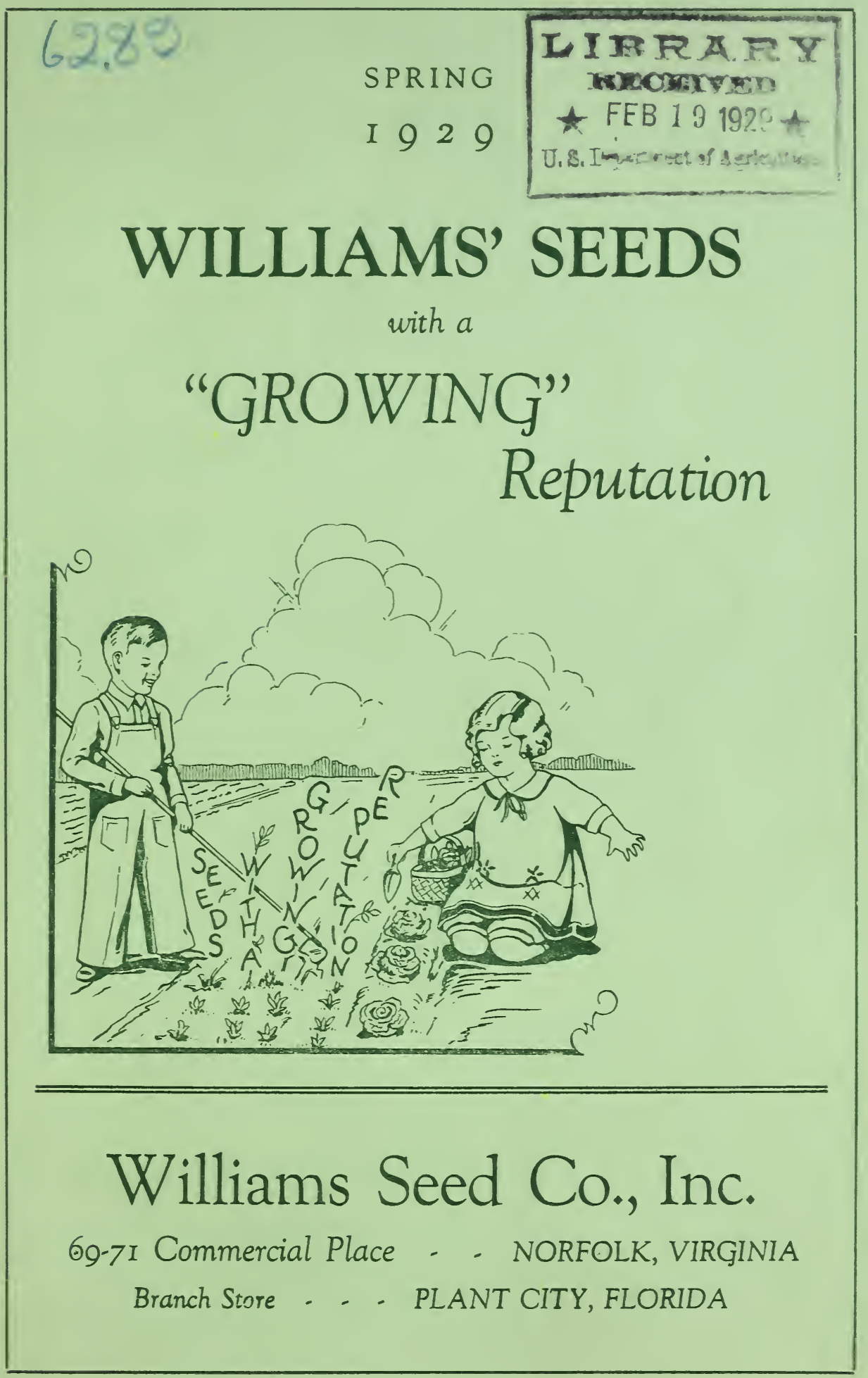




\section{GENERAL INFORMATION AND SUGGESTIONS}

\section{PRICES IN THIS CATALOGUE CANCEL ALL PRICE LISTS PREVIOUSLY ISSUED BY US}

All Goods in This Catalogue are offered subject to being unsold on receipt of order, and the prices quoted are subject to change without notice.

Advance Orders, Conditions of Acceptance. All advance orders, for growing crops, are booked by us previous to harvesting and receipt-subject to crops permitting - and accidents or delays beyond our control. Should shortages necessitate it, we reserve the right to fill such orders pro rata.

Please be careful to sign your name, postoffice, county, and state on each order and letter sent us. Each year we receive orders without name or address of sender.

Terms. All orders, to secure prompt shipment, should be accompanied with the cash. We can only send to well rated merchants, or parties well known to us, without the cash with order. When remittance falls short of amount of goods ordered, it is our custom to reduce the quantity sent, instead of delaying order by writing.

How to Send Money. By Post-Office or Express Money Order, Bank Check, or Draft, Cash by Registered Letter. We accept clean postage stamps for small amounts the same as cash.

C. O.D. Orders must be accompanied by a remittance equal to one-fourth the amount of the order; this insures the express or freight charges in case the goods are not taken when they arrive at destination.

We Forward As Customer Directs by express, freight, steamer or mail. When no shipping instructions are given we send according to our judgment.

We Guarantee the Safe Arrival in United States of all goods forwarded by express.

We Make No Charge for Packing Cases or Boxes, but we charge for cloth bags only, and these at cost. $1 / 4$ bu., $10 \mathrm{c}$; $1 / 2 \mathrm{bu}$., $15 \mathrm{c}$; 1 bu., $25 \mathrm{c}$; 2-bu., $45 \mathrm{c}$.

Error in the Filling of Orders. We use the greatest care in filling, checking and packing orders. Yet should anything be omitted we will promptly forward when advised. Keep a duplicate copy of your order for comparison.

Prepaid Orders. We prepay charges on all Broccoli, Cabbage, Cauliflower, Celery, Egg Plants, Pepper and Tomatoes at prices quoted herein when cash accompanies the order. Also all flower and vegetable seeds in packets, ounces, quarter pounds and pounds. This does not include these same articles (with the exception of the sorts named above) as quoted in ten and one hundred pound lots on which purchaser pays express or freight charges.

PARCEL POST RATES

\begin{tabular}{|c|c|c|c|c|c|c|}
\hline $\begin{array}{l}\text { 号 } \\
\text { 号 } \\
0 \\
0\end{array}$ & 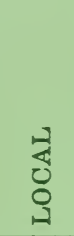 & 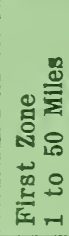 & 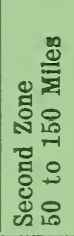 & 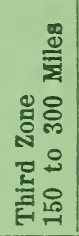 & 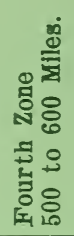 & 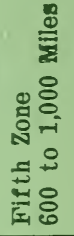 \\
\hline 1. & $\$ 007$ & $\$ 007$ & $\$ 007$ & $\$ 008$ & $\$ 009$ & $\$ 010$ \\
\hline 2. & 08 & 08 & 08 & 10 & 13 & 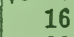 \\
\hline 3. & 08 & 09 & 09 & 12 & 17 & 2 \\
\hline 4. & 09 & 10 & 1 & 14 & 21 & 88 \\
\hline 5 & 09 & 11 & 11 & 16 & 25 & \\
\hline 6. & 10 & 12 & 1. & 18 & 29 & 40 \\
\hline $7 .$. & 10 & 1 & 1 & 20 & 33 & 46 \\
\hline & 11 & 1 & & 22 & 37 & \\
\hline & 11 & 15 & 1 & 24 & 41 & 5 \\
\hline 10 & 12 & 1 & 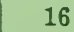 & 2 & 45 & 5 \\
\hline & 12 & $1^{\prime}$ & 1 & 2 & 49 & \\
\hline & 13 & 1 & & 30 & 53 & 76 \\
\hline 13 & 13 & 19 & 19 & 3 & 57 & 8 \\
\hline & 14 & 2 & & 34 & 61 & \\
\hline & 14 & & & 3 & 65 & \\
\hline 16 & 15 & 22 & 22 & 38 & 69 & 100 \\
\hline & 15 & 23 & 23 & 40 & 73 & 10 \\
\hline & 16 & & & & 77 & 1 \\
\hline & 16 & 20 & 20 & 44 & 81 & 118 \\
\hline & 17 & 26 & 26 & 46 & 85 & 12 \\
\hline
\end{tabular}

IMPORTANT-Seeds of the best quality will often fail through improper treatment. This may be due to one or more of several reasons, such as covering too deeply or not deeply enough, too much or too little water, too cold weather or a baking sun which forms a crust too hard for the tender shoots to penetrate. Sometimes insects destroy plants at the surface before they are seen by the gardener. WILLIAMS SEED COMPANY, Inc., gives no warranty, express or implied as to description, quality, productiveness, or any other matter of any seeds, bulbs, roots or plants they send out, and they will not be in any way responsible for the crop. 


\section{ALWAYS PLANT}

\section{Williams' Seeds With a "Growing" Reputation}

We are indeed pleased to present this, our 21 st annual and 1929 edition of our Catalog of vegetable and flower seeds. We confidently believe you will find every page of some interest to you and suggest that you keep it for reference.

Our special selection of vegetable seeds, well known by the prefix W. S. C., have become famous in all parts of the country due to their superior merits and are without a doubt the best that can be produced.

This is a year of acute shortages in most varieties of seeds, particularly in seed beans. We are fortunate in having a limited quantity of the principal varieties to offer our customers as long as they last, but would suggest early buying.

We hope you will find this book interesting, for we have tried to make it so. Please note the convenient order form in back of book. When ordering you may do so with full confidence, for in planting Williams' Seeds with a GROWING REPUTATION you have the promise of an assured crop.

Assuring you of our appreciation of your patronage and wishing you a prosperous year, we remain,

Sincerely yours,

WILLIAMS SEED COMPANY, INC.

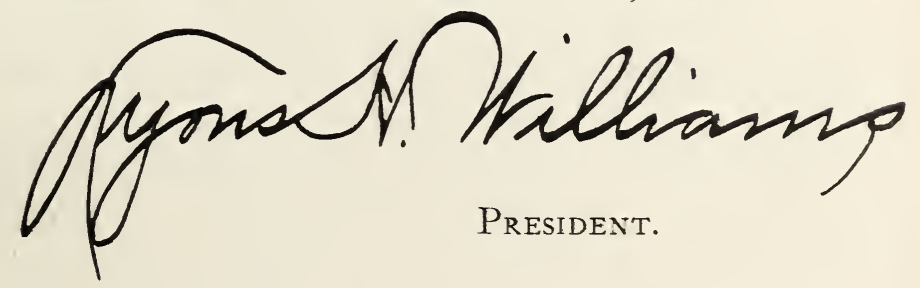




\section{The Time of Planting as Given Below Applies for Latitude of Norfolk, Va., Therefore Allowances Should Accordingly Be Made for More Northern or Southern Climates.}

JANUARY - If your hotbeds have not been prepared attend to them at once and sow Cabbage, Lettuce, Beets, Radish, Cauliflower and Onions. Sow hardy Flower Seeds in hotbeds for early blooming. Secure manure and cut pea and bean poles. Top-dress grain and grass fields with manure.

FEBRUARY --Sow in hotbeds or cold frames Cabbage, Lettuce, Beets, Radish, Cauliflower, Onions, Tomato, Egg Plant and Pepper. Latter part of the month sow in open ground Spring Kale, Beets, Spinach, Carrots, Celery, Radish, Parsley, and Early Peas. The latter part of the month put out Asparagus and Rhubarb Roots, Onion Sets, hardy Lettuce and Cabbage Plants. Plant Irish Potatoes on high, well-drained soil. Sow Lawn Grass, Winter Oats, Canada Field Peas, Grass and Clover Seeds.

MARCH-Sow under glass, Tomato, Pepper, Egg Plant, and Flower Seed. Sow outside, Garden Peas, Cauliflower, Cabbage, Lettuce, Beets, Radish, Parsley, Parsnip, Salsify, Carrots, Celery, Asparagus and Onions. Sow Herb Seed in warm borders. Plant Onion Sets, Potatoes, Asparagus and Rhubarb Roots. Transplant Early Cabbage, Lettuce and Cauliflower plants. Sow Dwarf Essex Rape, Canada Field Peas, Winter and Spring Oats, Grass and Clover Seed. Sow Lawn Grass.

APRIL_Finish sowing Canada Field Peas, Oats, Grass and Clover Seed, plant Potatoes. Bed Sweet Potatoes. Set out Asparagus, Rhubarb and Onions. Sow Cabbage, Lettuce and Tomatoes in open ground for succession. Sow Beets, Carrots, Celery, Radish, Salsify, Parsnip, Parsley, Spring Kale, Herbs, Mangel Wurzels. Set out Cabbage, Lettuce, Onions, and Beet Plants. Sow hardy Flower Seed outside. Plant Early Corn, Garden Peas, Snap Beans. Later in the month if the weather is favorable, plant Cucumbers, Melons, Squash, and Peanuts.

MAY - Finish planting early vegetables that were omitted last month. Plant all varieties of Dwarf and Pole Beans, Black-eye Peas, Cantaloupes, and Watermelons, Cucumber, Squash, Okra, Pumpkin and Stock Beets. Sow Tomato and Cabbage Seed for late crop. Set out Cabbage, Lettuce, Cauliflower, Tomato, Egg Plants, Pepper and Sweet Potato Plants. Sow Flower Seed and plant Flowering Bulbs. Plant Sugar and Field Corns. Sow Sorghum, Millet, Cow Peas, and all Fodder Plants.

JUNE-Sow Tomato and Cabbage for late crop. Plant Watermelons, Cantaloupes, Cucumbers, Squash and Pumpkin, Dwarf and Pole Beans, Stock Beets. Sow Millet, Sorghum, Soja Beans, and all other Fodder Plants.

JULY-For succession, plant Snap Beans, Sugar Corn and Dwarf Lima Beans. Plant Cucumbers for Pickles and Potatoes for late crops. Sow Rutabagas and Turnips, also Carrots and Beets for late crop. Set out Cabbage and Celery Plants. Sow Black-eye and Cow Peas, Soja Beans, Buckwheat and Millet.

AUGUST - This is the best month for sowing Turnip, Rutabagas and Winter Radish. Sow Spinach, Kale, Lettuce, Endive, and Corn Salad. Sow Snap Beans, Peas, Carrots, and Beets for late crop. Sow Crimson Clover, Vetch, Rape, Winter Oats, Rye and Barley for winter grazing. Set out Celery, Lettuce and Cabbage Plants, also put out Onion Sets.

SEPTEMBER-Sow Lettuce, Early Cabbage and Cauliflower for transplanting. Transplant Lettuce, Cabbage and Celery. Set out Onions, sow Turnips, Kale, Spinach, Winter Radish, Corn Salad and Endive. Sow Lawn Grass and all varieties of Grasses and Clovers. Sow Winter Oats, Rye, Barley, Rape, and Vetch.

OCTOBER-Finish sowing Cabbage, Lettuce, Turnips for Salad, Kale and Spinach. Sow Lawn Grass Seed. Finish sowing all varieties of Grass and Clover Seed. Sow Dwarf Essex Rape, Vetch, Oats, Wheat, Rye and Barley.

NOVEMBER-Set out Cabbage, Lettuce, Strawberry Plants and Asparagus Roots. Plant all kinds of Flowering Bulbs for spring blooming. This is the best month for setting out Fruit and Shade trees. Finish sowing all varieties of Grain and Grass as early in the month as possible. Sow Canada Field Peas with Grain.

DECEMBER - Early in the month sow Canada Field Peas and Rye, Cabbage, Radish, Lettuce and Beets can be sown in hotbeds.

\section{INFORMATION OF SPECIAL INTEREST}

For gardeners in the city who are crowded for room, some intensive methods which are easy of accomplishment should be mentioned, also some features to observe.

Set tomato plants or pepper plants 2 to 3 feet apart in rows of radish, beets or lettuce, provided that in the Spring the sowing was early.

Try Fordhook limas between potatoes 15 inches apart in rows. Limas cannot be planted until settled warm weather and at that time potatoes are forming and further hilling is injurious. When potatoes are dug carefully in line with row the small lima plants are not harmed.

Onion sets may be planted close to rows of vegetables in early Spring or Fall as catch crop, care being taken to judge early maturity. This applies of course to such regetables that cover but small space in row.

Tomatoes, peppers, eggplant, and similar fruit plants must have full sunlight. Do not set out in shady spots of the garden or near tall growing vegetables such as pole beans. 
One pound will plant 100 feet of row: 60 pounds will plant an acre.

Bountiful An absolutely stringless, flat, green-podded bush Bean. The plant is remarkably handsome and of thrifty growth, being practically rust and mildew proof. It is very hardy, rly, very prolific; it is the first to give pods fit to pick in the Spring, and the last to yield edible pods in the Fall, which are of immense size, thick, broad, extra long, meltingly tender and having a delicious flavor exciusively their own. Moreover, the pods are absolutely stringless, not only when young, but this tender "snap brittle" quality is retained even into maturity. Pkt., 15c: lb., $60 \mathrm{c} ; 2$ lbs., $\$ 1.00$, postpaid. 10 lbs., $\$ 4.50 ; 100$ lbs., $\$ 40.00$, not prepaid.

Extra Early Black Valentine An excellent strain of Valentine Bean that has market gardeners. This Bean will stand earlier planting than other varieties on account of it greater hardiness and its resistance to bad weather conditions. Extra early, a heavy bearer, and holds up splendidly in shipments to northern markets. The pods are long, straight, round, very handsome; are produced very profusely, and present a very attractive appearance. Pkt., 10c; lb., 50c: 2 lbs., 90 c, postpaid. 10 lbs., $\$ 3.00 ; 100$ lbs., $\$ 26.00$, not prepaid.

Giant Stringless Green Pod It is valuable for its extreme earliness and is absolutely Giant Stringless Green Pod stringless, which makes it one of our best extra early Beans, and wonderfully productive of pods of handsome appearance and finest quality. Extra early plantings will produce earlier crops; the later plantings will always produce pods the quickest. A very free bearer; entirely stringless; averages 5 inches long and is slightly curved. A handsome round-podded sort, borne on a healthy plant which stands dry weather well. Pkt., 15c; lb., 60c: 2 lbs., $\$ 1.00$, postpaid. 10 lbs., $\$ 4.50 ; 100$ lbs., $\$ 40.00$, not prepaid.

Refugee or 1000-to-1 This well known, hardy, vigorous, late sort is very productive and are 5 to 6 inches long, somewhat slender, round and slightly curved, canning purposes. The pods and of good quality, tender and meaty. They are brittle and of a light vines grow about 15 to 18 inches high, bushy in growth, and of strong habit. Pkt., 15c; lb., 55c: 2 lbs., $\$ 1.00$, postpaid. 10 lbs., $\$ 4.00 ; 100$ lbs., $\$ 35.00$, not prepaid.

EXTRA EARLY RED VALENTINE. Pods round, light green, very tender. Pkt., 10c; 1 lb., 50c; 2 lbs., 90c, postpaid. $10 \mathrm{lbs}$., $\$ 3.25 ; 100 \mathrm{lbs}$., $\$ 28.00$, not prepaid.

FRENCH LEADPENCIL. Long slender, straight, pods round and green. Pkt., 15c; 1 lb., 60c; 2 lbs., $\$ 1.00$, postpaid. 10 lbs., $\$ 4.00 ; 100$ lbs., $\$ 35.00$, not prepaid.

REFUGEE STRINGLESS. Very productive. Pkt., 10c; 1 lb., 60c; 2 lbs., \$1.00, postpaid. 10 lbs., $\$ 4.00 ; 100$ lbs., $\$ 35.00$, not prepaid.

LONGFELLOW. Moderately early and productive, straight, round dark green pods. Pkt., 15c; 1 lb., $60 \mathrm{c} ; 2$ lbs., $\$ 1.00$, postpaid. 10 lbs., $\$ 4.00 ; 100$ lbs., $\$ 35.00$, not prepaid.

BURPEE STRINGLESS. Early hardy vigorous and productive. Pkt., 10c; 1 lb., 55c; 2 lbs., \$1.00, postpaid. 10 lbs., $\$ 4.00 ; 100$ lbs., $\$ 35.00$, not prepaid.

\section{DWARF OR BUSH WAX-PODDED BEANS}

\section{W. S. C. Early Harvest Wax-Crop Failed}

CURRIES RUSTPROOF WAX. Pod long, golden, broad and flat. Pkt., 15c; 1 lb., 55c; 2 lbs., \$1.00, postpaid. $10 \mathrm{lbs}$., $\$ 4.00$; $100 \mathrm{lbs.,} \$ 35.00$, not prepaid.

HODSON WAX. Very long flat pods. A late variety. Pkt., 15c; 1 lb., 60c; 2 lbs., \$1.00, postpaid. 10 lbs., $\$ 4.00 ; 100$ lbs., $\$ 35.00$, not prepaid.

SURE CROP STRINGLESS WAX. A fine variety. Pkt., 15c; 1 lb., 5̃ăc 2 lbs., \$1.00, postpaid. 10 lbs., $\$ 4.00 ; 100$ lbs., $\$ 35.00$, not prepaid.

WARDWELL'S KIDNEY WAX. Good quality stringless, flat pod. Pkt., 10c; 1 lb., 60c; 2 lbs., $\$ 1.00$, postpaid. 10 lbs., $\$ 4.00 ; 100$ lbs., $\$ 35.00$, not prepaid.

\section{BUSH LIMA BEANS}

One pound will plant about 100 hills or 100 feet of row; 60 lbs. per acre.

Fordhook Bush Lima Generally considered the best of the large-seeded bush Lima variebranches held upright. This is a ties. Bushes of strictly erect habit, branching freely with all the seeded, bush Lima. From 4 to 6 days earlier than others of the varieties of this class. Pods are found in clusters of 4 to 8 , and are well filled with delicious, large beans that in quality surpass by far all other Lima Beans. Pkt., 15c; lb., 75c; 2 lbs., $\$ 1.40$, postpaid. 10 lbs., $\$ 5.00 ; 100$ lbs., $\$ 40.00$, not prepaid.

Burpee's Improved Bush Lima Both beans and pods larger than the old type, and thicker than in the old form. Pkt., 15c; $1 \mathrm{lb.,60c;2} 1 \mathrm{lbs}$., $\$ 1.00$, postpaid. 10 lbs., $\$ 4.00 ; 100$ lbs. $\$ 35.00$, not prepaid.

DREER'S BUSH LIMA. A thick seeded or potato type of dwarf lima of high quality. Pkt., 10c; 1 lb., $60 \mathrm{c} ; 2$ lbs., $\$ 1.00$, postpaid. $10 \mathrm{lbs} ., \$ 4.00 ; 100 \mathrm{lbs}$., $\$ 35.00$, not prepaid.

HENDERSON BUSH LIMA (Bush Butter Bean). Very early and popular, very productive. Pkt., 10c; 1 lb., 50c; 2 lbs., 90c, postpaid. 10 lbs., $\$ 3.00 ; 100$ lbs., $\$ 25.00$, not postpaid.

PROLIFIC BUSH LIMA. Quite similar to Henderson Bush but beans are somewhat larger and thicker. Pkt., 15c; 1 lb., 50c; 2 lbs., 90c, postpaid. 10 lbs., $\$ 3.00 ; 100$ lbs., $\$ 25.00$, not postpaid. 


\section{POLE LIMA BEANS}

Early Leviathan This is the earliest large-podded pole Lima that we know. Very large pods are produced in clusters and in great abundance, often containing size and of the finest quality. Pkt., 10c; lb., 50c; 2 lbs., 90c, postpaid. 10 lbs., $\$ 3.00 ; 100$ lbs., $\$ 25.00$, not prepaid.

KING OF THE GARDEN. An improved strain of large white lima. Prt., 10c; 1 lb., 45c; 2 lbs., 85c, postpaid. 10 lbs., $\$ 2.50 ; 100$ lbs., $\$ 22.00$, not prepaid.

CAROLINA or SIEVA (Pole Butter Bean). Plant of large growth, very early, vigorous and productive. Beans small and white. Plt., 10c; 1 lb., 45c; 2 lbs., 85c, postpaid. 10 lbs., $\$ 2.50 ; 100$ lbs., $\$ 22.00$, not prepaid.

WOOD'S IMPROVED POLE LIMA (Butter Bean). Of similar type to the Sievas but beans are larger. Plat., 10c; 1 lb., 50c; 2 lbs., 90c. 10 lbs., $\$ 3.00 ; 100$ lbs., $\$ 25.00$, not prepaid.

FLORIDA BUTTER. Seed of "Sieva" size but speckled white and brownish red. Pkt., 10c; 1 lb., 45c; 2 lbs., $85 \mathrm{c}$, postpaid. 10 lbs., $\$ 2.50 ; 100$ lbs., $\$ 22.00$, not prepaid.

\section{BEANS-CLIMBING OR POLE}

Old Homestead, or Kentucky Wonder This variety we consider superior to enormously productive, early and continuous bearer; large green pods in great clusters, stringless and tender. Plt., 10c; lb., 40c; 10 lbs., \$2.50, postpaid. 100 lbs., $\$ 20.00$, not prepaid.

\section{SUGAR OR SWEET CORN}

One pound will plant about 200 hills; 12 pounds will plant an acre.

Golden Bantam The plant is only 4 to 5 feet high and it grows so compactly that it may Golden Bantam find a place in the smallest garden. The ears, though small, are of a most convenient size for the table, just right to serve whole. They are filled from butt to tip with deep, broad grains of attractive color and most delightful flavor. Plt., 10c; lb., 35c, postpaid. 10 lbs., $\$ 2.00 ; 100$ lbs., \$18.00, not prepaid.

Stowell's Evergreen This is considered the standard late or main-crop variety throughout the country. Our strain of this is extra choice and we spare no The stalks grow 7 to 8 feet high. Ears average 8 inches long, are well filled with numerous rows of slim, deep kernels of good quality. The standard for canners. Plt., 10c; lb., 10c, postpaid. $10 \mathrm{lbs} ., \$ 2.25 ; 100 \mathrm{lbs} ., \$ 16.00$, not prepaid.

Black Mexican Medium early, bearing 8-inch ears, well filled with large kernels, which, exceptionally sweet. Pkt., 10c; lb., 35c, postpaid. 10 lbs., $\$ 2.00 ; 100$ lbs., $\$ 18.00$, not prepaid.

C'ountry Gentleman Small white cob with irregular rows of very long slender white not prepaid.

Hickory King The grain is so wide and deep and the cob so small that often a single grain stalk. Lb., 20c, postpaid. Peck (14 lbs.), \$1.00; bushel, (56 lbs.), \$3.50, not postpaid.

Truckers' Favorite A standard early white variety, useful either as early roasting ears or (56) lbs., $\$ 5.00$, not prepaid.

Norfolk Market The most popular kind among our market gardeners. Very hardy, and has OIIOL Market ready gale either in green state or matured. The ears are about 8 inches long: 14 to 16-rowed, and well filled. The grains are plump and milky when green, of exceptional quality. Plt., 10c; lb., 25c; 2 lbs., 15c, postpaid. Peck, $\$ 1.50$; bushel (56 lbs.), \$5.60, not prepaid.

W. S. C. Virginia Yellow Dent One of the best standard yellow varieties for this section, making a good growth of stalk and fodder, 作 sorts. Our stock is carefully selected each year and will be found entirely satisfactory in every reapect. Lb., 20c, postpaid. Peck (14 lbs.), \$1.25; bushel (56 lbs.), \$4.00, not prepaid.

\section{MUSTARD}

Southern Giant Curled The leaves are large, colored light green, with a yellow tinge, slightly spreading in growth, and is very hardy, and of good quality. Plet., 10c; oz., 15c; 1/4 lb., 25c; lb., $75 \mathrm{c}$, postpaid.

Broad-Leaved The leave are large, comparatively smooth and have a distinct broad midrib. It produces considerably more leaf growth than other sorts and the leaven, when cooked, are of excellent quality. Pkt., 10c; oz., 15c; 1/4 lb., 25c; lb., 75c, postpaid.

FORDHOOK FANCY. A handsome vigorous growing mild variety. Plt., 10c; oz., 15c; 1/4 lb., 25c; lb., 75c, postpaid. ELFPHANTS EAR. Produces extra large leaves of heavy substance. Pkt., 10c; oz., 15c; 1/4 lb., 25e: 


\section{BEET}

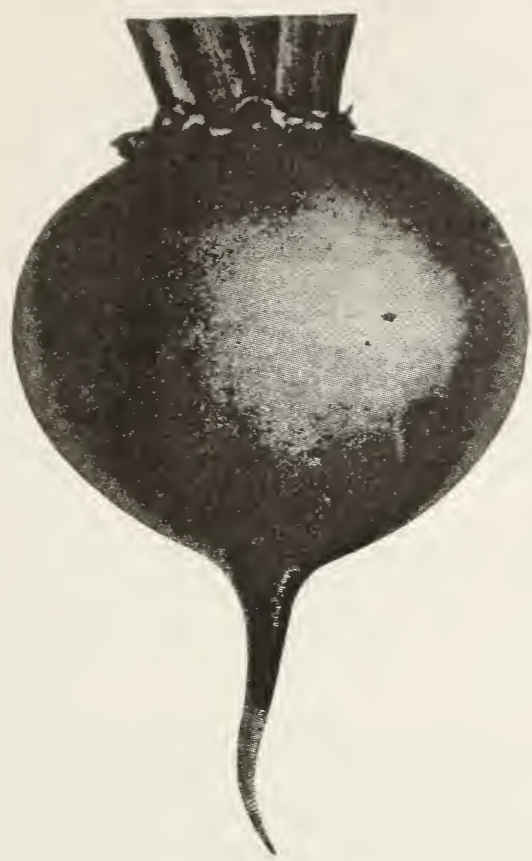

Beet, W. S. C. Crimson Beauty.

One ounce will sow 50 feet of drill; six to eight pounds to an acre.

W.S. C. Early Crimson Beauty A fine selection of blood-red Beet, extremely desirable shape. We recommend it not smooth and of symmetrical growth, rich color and ther or it is peerless: very fine grained, tender and sweet, never woody or stringy. Color of both skin and flesh, deep, rich crimson, equaling that of the best long beets. Pkt., 10c; oz., 20c;1/4 1b., 50c; 1b., \$1.50; 10 lbs., $\$ 14.00$, postpaid. Early Wonder An improved strain of the standard Crosbys. Roots are very uniform, nearly with very little zoning. Most popular with market gardeners for early or late planting. The care taken in its selection makes it cost more, but it is certainly worth the price. You will make no mistake in buying the Early Wonder. Pkt., 10c; 0z., 15c; 1/1 1b., 35c; lb., $\$ 1.25 ; 10$ lbs., $\$ 10.00$, postpaid.

CROSBY'S EGYPTIAN. An improvement over Egyptian, being equally as early, larger, and less flat, very uniform in size and shape, with small foliage. Flesh of excellent quality and of a distinct red slightly zoned. Plkt., 10c; oz., 15c; 1/4 lb., 35̃c; lb., \$1.00; $10 \mathrm{lbs.,} \mathrm{\$ 9.00,} \mathrm{postpaid.}$

DETROIT DARK RED. One of the very best for home or market garden and for canning purposes. Roots uniformly smooth, of medium size, and globe shaped; skin, dark red; flesh, solid vermillion red. Plt., 10c; ex., 15e; $1 / 4$ lb., 35c; lb., $\$ 1.00 ; 10$ lbs., $\$ 9.00$, postpaid.

ECLIPSE. One of the best to follow after the very early sorts. When young it may be bunched, but it is also used as a basket beet, and is known and sells freely on every market. It is medium in ize, the tops small for size of root, the outer color is dark and the flesh blood red. Pkt., 10c; oz., 15c; $1 /$ lb., $35 \mathrm{c}$; lb., $\$ 1.00 ; 10$ lbs., $\$ 8.50$, postpaid.

EGYPTIAN. (Extra Early Flat.) A quick maturing, early variety, very dark colored; should be used when young. Plt., 10c; oz., $15 \mathrm{c}$; 1/4 lb., 35c; lb., \$1.00; $10 \mathrm{lbs} ., \$ 9.00$, postpaid.

\section{Swiss Chard or Spinach Beet}

One ounce will sow 100 feet of row.

GIANT LUCULLUS. A type of Beet which is grown principally for the leaves which can be cooked like Spinach. Plt., $10 \mathrm{c} ; 0 \mathrm{z} ., 15 \mathrm{c} ; 1 / 4 \mathrm{lb} ., 35 \mathrm{c}$; lb., $\$ 1.00$, postpaid.

Broccoli-Italian Green Heading A very great demand has been created for this nence the past few years. It is easy of culture and very healthful. The plant forms a large solid hesd which remains green. After this head is cut, numerous sprouts develop from the leaf axes, each prout terminating in small green heads which are bunched for market. Pltt., 25c; oz., \$2.75; 1/. lb., $\$ 10.00$; lb., $\$ 35.00$, postpaid.

Broccoli Salad A comparatively new salad which is cultivated similar to turnips. The seed Stalks are cut or broken off at base when about six inches high and just before bods open into blossom. They may either be used as a raw salad or cooked like asparagus. As fast as seed stalks are removed others come five or six times. Plt., 10c; 0z., 40c; 1/4 $1 \mathrm{~b} ., \$ 1.00 ;$ Ib., \$3.00, pestpaid. 


\section{CABBAGE}

One ounce will give 2000 to 2500 plants; $1 / 4$ to $1 / 2 \mathrm{lb}$. sufficient for an acre.

W.S.C. Copenhagen Market A quality variety with round heads averaging about small core. The plants are short-stemmed, the pounds in weight. They are very solid, and have a ground. It is ready for market fully as soon as Early Jersey Wakefield, and gives a heavier yield per acre than that popular Cabbage. A most productive variety, attractive, and always tightly folded. Undoubtedly the best Cabbage for all conditions. Good for market growing and home garden. Heads medium size, firm and round. Our seed is a pedigreed type of selected Danish grown stock. Pkt., 10c; oz., 40c; $1 / 4$ lb., $\$ 1.15 ; \mathrm{lb} ., \$ 4.00$, postpaid.

\section{W.S. C. Early Jersey Wakefield}

(Special Selected Stock). Wakefield Cabbage is among market growers is planted entirely for the first early market. mands that more than ordinary attention be given to the selection of plants for breeding purposes, having in mind earliness, sureness to head, solidity and uniformity of growth and maturity. In our Wrkefields this careful selection has been critical and continued through many years, and we believe we have as good and uniform a strain as can be had. They are early, hardy and uniform, and make but few outside leaves. Jersey Wakefield makes solid, pointed heads of good size and of most excellent quality. Pkt., 10c; oz., 40c; 1/4 lb., \$1.10; lb., \$4.00, postpaid.

\section{W. S. C. Charleston Wakefield} purity and excellence of our Jersey Wakefield is is pure and true a strain as careful selection can make it. It is a week to ten days later than Jersey Wakefield, equally as solid, but considerably larger; has a less pointed and thicker head. Its earliness, hardiness, size and solidity have contributed to make it one of the most universally grown early Cabbages. Pkt., 10c; oz., 40c; 1/4 lb., \$1.10; lb., $\$ 4.00$, postpaid.

EARLY VARIETIES.

Extra Early Eureka An extra early small flat, hard-heading variety. Can be set very lb., \$4.00, postpaid.

Early Jersey Wakefield. The conical heads are uniformly hard and solid. A productive variety. Pkt., 10c; oz., 25c; $1 / 4$ lb., 75c; lb., $\$ 2.75$, postpaid.

Charleston Wakefield. Very choice and uniform, though we consider our W.S. C. Charleston Wakefield superior. Pkt., 10c; oz., 25c; $1 / 4 \mathrm{lb}$., $75 \mathrm{c}$; lb., $\$ 2.75$, postpaid.

Copenhagen Market. The heads are remarkably solid, of fine quality. Heads average about eight pounds each. Pkt., 10c; oz., 25c; 1/4 lb., 85c; lb., \$3.00, postpaid.

Golden Acre. An extra early selection of the Copenhagen type. Plant small, dwarf and compact. Pkt., 15c; oz., 50c; $1 / 4$ lb., $\$ 1.75$; lb., $\$ 6.00$, postpaid.

Pilot. This variety is ready for market or table use in about 75 to 80 days after sowing the seed. It is the earliest variety grown, but does not have as hard a head as the later varieties. Leaves grow compactly together and it may be planted very closely. Pkt., 10c; oz., 40c; 1/4 lb., $\$ 1.10$; lb., $\$ 4.00$, postpaid.

\section{SECOND EARLY or SUMMER VARIETIES.}

All-Head Early. One of the largest second early sorts; excellent quality. It is remarkably solid, deep, flat and very uniform. Pkt., 10c; oz., 25c; 1/4 lb., 70c; lb., $\$ 2.50$, postpaid.

Early Flat Dutch. A very valuable second early variety. The plants are short-stemmed and upright, and can be set very close together. The head is solid, nearly round and very uniform in size and shape. Pkt., 10c; oz., 25c; 1/4 lb., 70c; lb., \$2.50, postpaid.

Early Summer. A variety largely used for second early and an exceptionally good Cabbage. Pkt., 10c; oz., 30c; 1/4 lb., 85c; lb., $\$ 3.00$, postpaid.

Succession. Heads very large and somewhat flat. Very solid. Pkt., 10c; oz., 25c; 1/4 lb., 75c; lb., $\$ 2.50$, postpaid.

LATE or WINTER VARIETIES.

Danish Winter Ballhead, or Hollander. (Short stem.) A splendid large, hard-heading variety. Pkt., 10c; oz., 30c; 1/4 lb., 85c; lb., \$3.00, postpaid.

Premium Flat Dutch. Heads large, solid, broad, and flat on top. Excellent Winter variety. Pkt., 10c; oz., 25c; $1 / 4$ lb., 70c; lb., $\$ 2.50$, postpaid.

Mammoth Red Rock. Heads are always deep red color and extremely solid. Average weight abcit ten pounds each. Pkt., 10c; oz., 30c; 1/4 lb., 85c; lb., \$3.00.

Perfection Drumhead Savoy. The Savoy Cabbage is not grown as much as it should be. The quality is very fine, especially after frost. Pkt., $10 \mathrm{c} ; 0 z ., 30 \mathrm{c} ; 1 / 4 \mathrm{lb} ., 85 \mathrm{c} ; \mathbf{l b . ,} \$ 3.00$, postpaid.

Chinese Improved or Pe-Tsai. When well grown the strain we offer resembles Cos Lettuce rather than Cabbage. It is served as a salad like lettuce or cooked like asparagus. Pkt., 10c; oz., 30c; 1/4 lb., $85 \mathrm{c} ; 1 \mathrm{~b} ., \$ 3.00$, postpaid. 


\section{CAULIFLOWER}

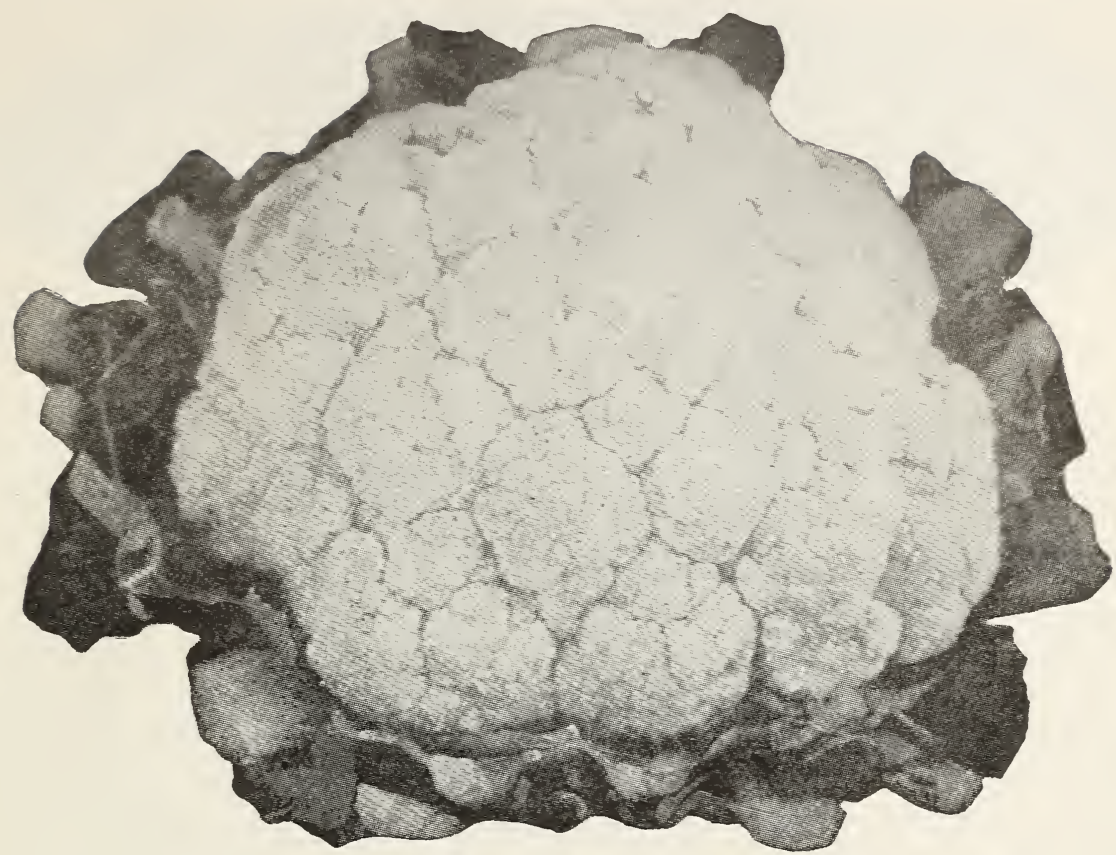

Cauliflower, W.S. C. Snow Queen.

One ounce of seed will give 1500 plants, $1 / 4$ to $1 / 2$ pound sufficient for an acre. W. S. C. Early Snow Queen Early Snow Queen Cauliflower is by far the quickest will make a head where other varieties fail to succeed. Gardeners should give this variety a flower has always a ready market, and anyone who grows our strain will make a sure success. Pkt., 25c; oz., $\$ 3.00 ; 1 / 4$ lb., $\$ 11.00 ; 1 b ., \$ 40.00$, postpaid.

Early Snowball An extra early variety, but has become popular for later use, having dis. produces snow-white heads, averaging 8 to 10 inches in diameter. It is small-leaved and is grown extensively under glass during Winter and Spring. Its close growing, compact habit permits planting one-third more on the same space of ground than with other varieties. Pkt., 25c; 02., \$2.75; 1/4 lb., $\$ 8.50 ; 1 b ., \$ 30.00$, postpaid.

Extra Early Dwarf Erfurt A very choice strain of the popular Erfurt type, regrowth with smooth curd. Pkt., $25 \mathrm{c}$; oz., $\$ 2.50 ; 1 / 4 \mathrm{lb}$., $\$ 7.50 ; \mathrm{lb}$., $\$ 28.00$, postpaid.

Veitch's Autumn Giant A large late Cauliflower producing quite compact white heads surrounded by a mass of large spreading leaves. Like all late $1 / 4$ lb., $\$ 2.50 ; 1 b ., \$ 9.00$, postpaid.

KALE, or BORECOLE (1 oz. for 150 feet of drill)

Pkt. Oz. $\quad 1 / 4$ lb. Lb.

Jamaica Extra Dwarf Curled Scotch. Similar but far superior to Dwarf Curled Scotch. Dark in color

Norfolk Drarf Curled Scotch. Extra fine curled, bright green leaves, tender and fine

$\begin{array}{llll}.10 & .20 & .45 & 1.50 \\ .10 & .15 & .25 & .85 \\ & .10 & .25 & .75 \\ & .10 & .15 & .35\end{array}$

(Sprouts). A very hardy variety. Popular Spring, or Smooth Kale. A hardy, quick-growing smooth-leaved variety_-

Hanorer Salad. A rapid-growing "green" that can be sown in the Spring or Fall. Being so easily grown, it should be in every home garden 


\section{CELERY}

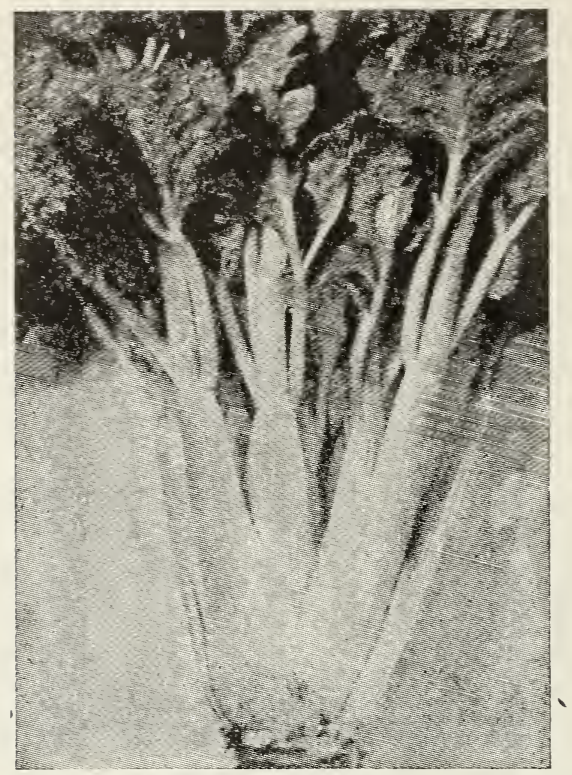

Celery, Wonderful.

One ounce for 3,000 plants.

Culture Celery seed is very small and the seed should be sown in partly-shaded beds, the soil having been worked down very fine. The seed should be scattered thinly on the surface then barely covered with finely sifted soil, not covering over a quarter inch. Keep bed well moistened but not soaking wet. Transplant to open ground when about 6 inches high and about 6 to 8 inches apart in the row. As plants grow keep hilling up to bleach.

\section{Wonderful or Golden Plume (Special Grown Seed). Our special stock of Golden} derfal success with all larger celery growers in Plume or Wonderful Celery has proved such a wonstock seed. This seed is grown especially for us from the originator's stock seed in larger quantities each year. This variety is grown largely for market but it is equally as valuable for private garden. It is early, blanches quickly and its rich color makes it quite attractive. The habit of plant is tall and the stalks are broad, thick, very solid, crisp and brittle, the quality is superior, tender and free from stringiness, flavor rich and delightful. It develops a large heart and the greater part of the plant is edible. The seed which we offer we believe to be as good as can be grown. Plkt., 15c; oz., $\$ 1.50$; $1 / 4 \mathrm{lb}$., $\$ 5.50$; $1 \mathrm{~b}$., $\$ 20.00$, postpaid.

Golden Self Blanchino (French Growi). A splendid early Celery which makes vigorous Gell Blanching growth and grows to a large size. The heart is rich golden yellow with light yellowish green outer stalks. Its delicate flavor is surpassed by no other variety and moreover it has the decided merit of being self-blanching to a very remarkable degree. We offer the new tall strain. Plkt., 15c; oz., 85c; 1/4 lb., \$3.25; lb., \$12.00, postpaid.

Golden Self Blanching (American Grown). Similar to the above but slightly shorter. $10 \mathrm{c}$; oz., $65 \mathrm{c}$; $1 / 4 \mathrm{lb} ., \$ 2.25$; $1 \mathrm{~b}$., $\$ 8.00$, postpaid.

WINTER QUEEN. The best Winter Celery. It blanches easily, has a crisp, nutty flavor, is hardy and a splendid keeper. Pkt., 10c; 0z., 25c; 1/4 lb., 75c; lb., \$2.50, postpaid.

GIANT PASCAL. Thick, solid stalk, golden hearts; blanches quickly; keeps well and is of good flavor. Pkt., 10c; oz., $25 \mathrm{c} ; 1 / 4 \mathrm{lb}, 75 \mathrm{c}$; lb., $\$ 2.50$, postpaid.

\section{Celeriac or Turnip Rooted Celery}

Large Smooth Prague Gromn exclusively for its roots, which are turnip-shaped, very smooth, tender, and narrow-like. The roots are cooked and flavoring soups. Pkt., 10c; 0z., 25c; 1/4 lb., 75c; lb., \$2.50, postpaid.

ENDIVE ( 1 oz. for 100 feet of drill)

Broad-Leaved Batavian, or "Escarolle." One of the best salads, especially when blanched; also much used for garnishing; if boiled, makes fine "greens". Pkt., 10c; oz., 20c; 1/4 lb., 40c; 1b., \$1.25, postpaid.

Green Curled. Has very curly leaves, the midrib being white and blanched and the outer edge very much indented and crested. A very attractive plant and one of the very best varieties. Pkt., 10c: oz., $20 \mathrm{c} ; 1 / 4 \mathrm{lb}$ lb, $45 \mathrm{c}$; lb., $\$ 1.50$, postpaid. 


\section{CUCUMBERS}

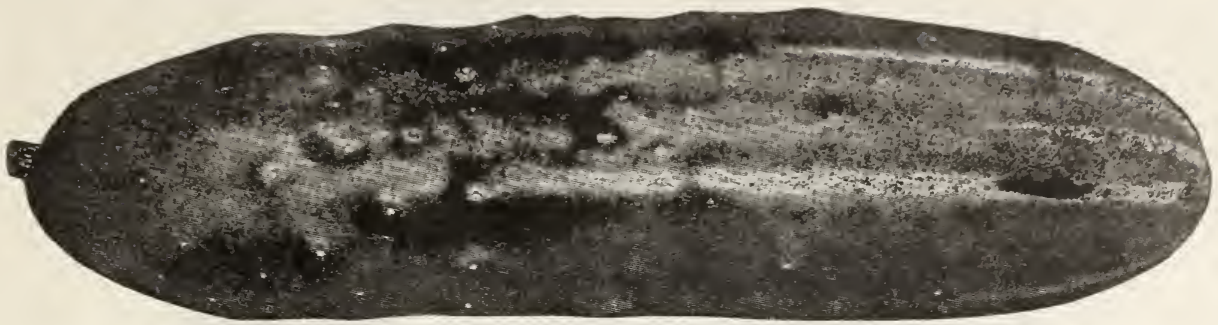

Cucumber, W. S. C. Nugreen.

One ounce of seed will plant 60 hills; 2 to 3 lbs. per acre.

W. S. C Nugreen For a long distance shipping Cucumber that will retain its rich dark green color better and remain edible longer than almost any other White disease-resistant; fruits nine inches long, slightly tapering; flesh white, very firm and crisp with very few seeds. The skin is smooth and the fruits are uniform and symmetrical; of a rich, dark green color. Pkt., 15c; 0z., 25c; 1/4 lb., 60c; lb., $\$ 1.75 ; 10$ lbs., $\$ 16.00$, postpaid.

W. S. C. Famous Peerless It is an early, prolific and continuous producer of uniformly color. It runs very close to type, bearing practically no mis-shapen fruit or culls. It is ideal for slicing, flesh being compact, fine grained, sparkling white and of most refreshing and delightful flavor. The vines are vigorous, quite healthy, mildew-proof, maintaining their luxuriance and bearing from the earliest to the latest season. Either for home garden or market this variety is without a peer. Pkt., 10c; 0z., 15c; 1/4 lb., 30c; lb., $\$ 1.00 ; 10$ lbs., $\$ 9.00$, postpaid.

Williams' Success White Spine In earliness, productiveness and color-retaining Oine qualities we believe it to be unsurpassed by an white White spine and with white, crisp, tender flesh. Pkt., 10c; oz., 15c; $1 / 4$ lb., 50c; lb., $\$ 1.50 ; 101$ lbs..

ARLINGTON WHITE SPINE. Midseason variety of medium size. Pkt., 10c; oz., 15c; 1/4 lb., 30c; lb., $\$ 1.00 ; 10$ lbs., $\$ 9.00$, postpaid.

DAVIS PERFECT. An extra long dark green type of white spine. Flesh crisp and solid with few seeds. Pkt., 10c; 0z., 15c; 1/4 lb., 40c; lb., \$1.25; 10 lbs., \$11.50, postpaid

EARLY FORTUNE. One of the best white spine, long, dark green fruits. Pkt., 10c; 0r., 15c; 1/4 Ib., $40 \mathrm{c} ;$ lb., $\$ 1.25 ; 10$ lbs., $\$ 11.50$, postpaid.

HENDERSON PERFECTED. An extra early dark green white spine strain. Pkt., 10c; 0z., 15c; 1/4 lb. $30 \mathrm{c} ; \mathrm{lb.}, \$ 1.00 ; 10$ lbs., $\$ 9.00$, postpaid.

LONG GREEN. Dark green fruits, 12 to 14 inches long. It is the best variety for long yellow picklea. Pkt., 10c; oz., 20c; 1/4 lb., 50c; lb., \$1.50; 10 lbs., $\$ 13.50$, postpaid.

\section{CARR0TS}

One ounce of seed for 100 feet of drill, 3 to 4 pounds for an acre.

W. S. C. Pride of the Market This new stump-rooted variety we consider the best of its class. It's a half-long sort unexcelled in quality diameter at base. Pkt., 10c; oz., 15c; 1/4 lb., $45 \mathrm{c} ; 1 \mathrm{lb}$. $\$ 1.50$, postpaid.

Chantenay Half-Long or Model we recommend this variety as the best of the very even in shape and size-about 6 to 7 inches skin is clean, smooth, and of a deep orange color. The flesh is fine grained and free from core, excellent in flavor and quality. Pkt., $10 \mathrm{c} ; 0 \mathrm{z.}, 15 \mathrm{c} ; 1 / 4$ lb., $40 \mathrm{c} ; 1 \mathrm{~b} ., \$ 1.25$, postpaid.

Danvers Half Long The roots are smooth, 8 to 10 inches long, of a deep orange color. is an excellent variety either for the home garden or for the market. Pkt., 10c; 0z., 15c; 1/4 1b., 40c; lb., $\$ 1.00$, postpaid.

Improved Long Orange The roots grow uniform and smooth, 8 to 10 inches long, of and leep, rich orange color. It is a good keeper lb., $\$ 1.00$, postpaid.

Oxheart or Guerande One of the most popular and heaviest yielders among the short tapers slightly to the bottom, and is very stump-rooted. Pkt., 10c; oz., 15c; 1/4 lb., 40c; lb., \$1.00, postpaid.

Rubicon Half-Long The best in shape, and its deep red-orange colored flesh is of finest same length; extremely well adapted for early forcing and for growing outside. Pkt., 10c; oz., 15c: $1 / 4$ lb., 40c; lb., $\$ 1.25 ; 10$ lbs., $\$ 10.00$, postpaid. 


\section{EGGPLANT}

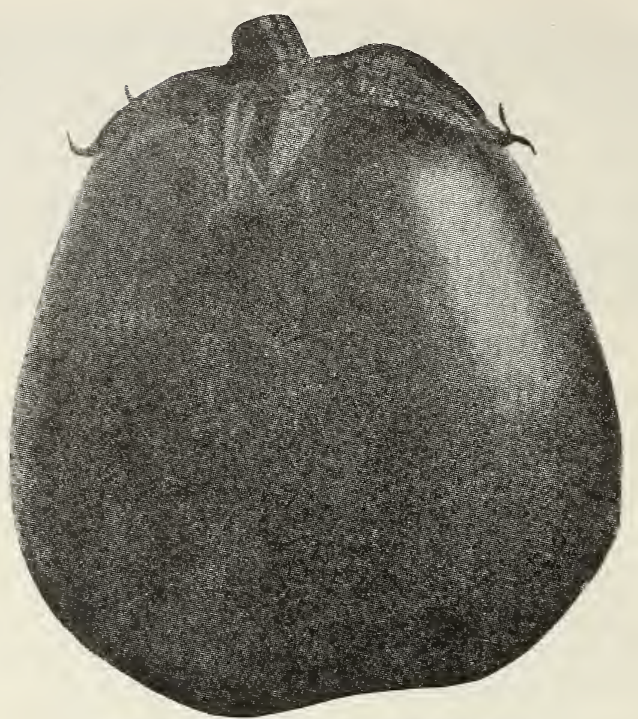

Egg Plant, W. S. C. Black Beauty.

One ounce of seed will produce 1500 plants; 6 ounces will sow an acre.

W. S. C. Black Beauty The earliest and best of all large-fruited Eggplants. It is valuable W. S. C. Black Beauty produces fruits fully as large and ready for use ten days to two weeks earlier than the New York Improved Purple. The plants branch very freely near the ground and grow in well rounded bushes. The grand, large fruits are thick, of most attractive form. The skin is a rich lustrous purplish black - the satin gloss and rich coloring adding greatly to its beauty. The intensely brilliant coloring is uniform over the whole fruit and does not fade or change to a lighter coloPlt., 15c; oz., 75c; 1/4 lb., \$2.75; lb., \$10.00, postpaid.

BLACK BEAUTY. Color very dark purple, almost black. Productive. Pkt., 10c; oz., 75c; 1/4 lb., $\$ 2.00$ : lb., \$7.00, postpaid.

FLORIDA HIGH BUSH. Of strong upright growth, holding its fruit well above ground. Pkt., 10e: ox., 50c; 1/4 lb., $\$ 1.75$; lb., $\$ 6.00$, postpaid.

NEW YORK IMPROVED SPINELESS. A favorite market variety large oval fruits of dark purple color. Pkt., 10c; oz., 50c; $1 / 4$ lb., $\$ 1.50$; lb., $\$ 5.00$, postpaid.

\section{OKRA, OR GUMBO}

One ounce will sow 100 feet of row; 8 lbs. will sow an acre.

W.S. C. Dwarf Stalk Long Green Pod Dwarf, but immensely productive. The pods are tender, of the best quality, Pkt., 10c; oz., 15c; 1/4 lb., 35c; lb., $\$ 1.25 ; 10 \mathrm{lbs} ., \$ 10.00$, postpaid.

PERKINS MAMMOTH. Very early and productive. Pkt., 10c; oz., 15c; 1/4 1b., 25c; lb., 75c, postpaid.

\section{ONION}

For sets, use from 30 to $40 \mathrm{lbs}$. to the acre.

One ounce of seed for 100 feet of drill; 5 to $6 \mathrm{lbs}$. for an acre.

BERMUDA WHITE. Early and productive, grown largely in Southern States. Pkt., 10c; oz., 30c: $1 / 4$ lb., $85 \mathrm{c}$; lb., $\$ 3.00$, postpaid.

BERMUDA YELLOW. The standard varieties for shipping. Very sweet and mild. Pkt., 10c; oz., 30c; $1 / 4$ lb., 85c; lb., $\$ 3.00$, postpaid.

CRYSTAL WHITE WAX. A pure white, flat onion, largely grown in Texas for early northern markets. Pkt., 10c; oz., 50c; $1 / 4$ lb., $\$ 1.50 ; 1 b ., \$ 5.00$, postpaid.

PRIZETAKER. Mammoth yellow globe, large producer on light soils. A favorite everywhere. Pkt., $10 c$; 0z., 25c; $1 / 4$ lb., 65c; lb., $\$ 2.50$, postpaid.

WHITE QUEEN. A very early, white clear skinned variety used for bunching when young. Excellent for small pickles. Pkt., 10c; 0z., 25c; $1 / 4$ lb., 65c; lb., \$2.50, postpaid. 


\section{LETTUCE}

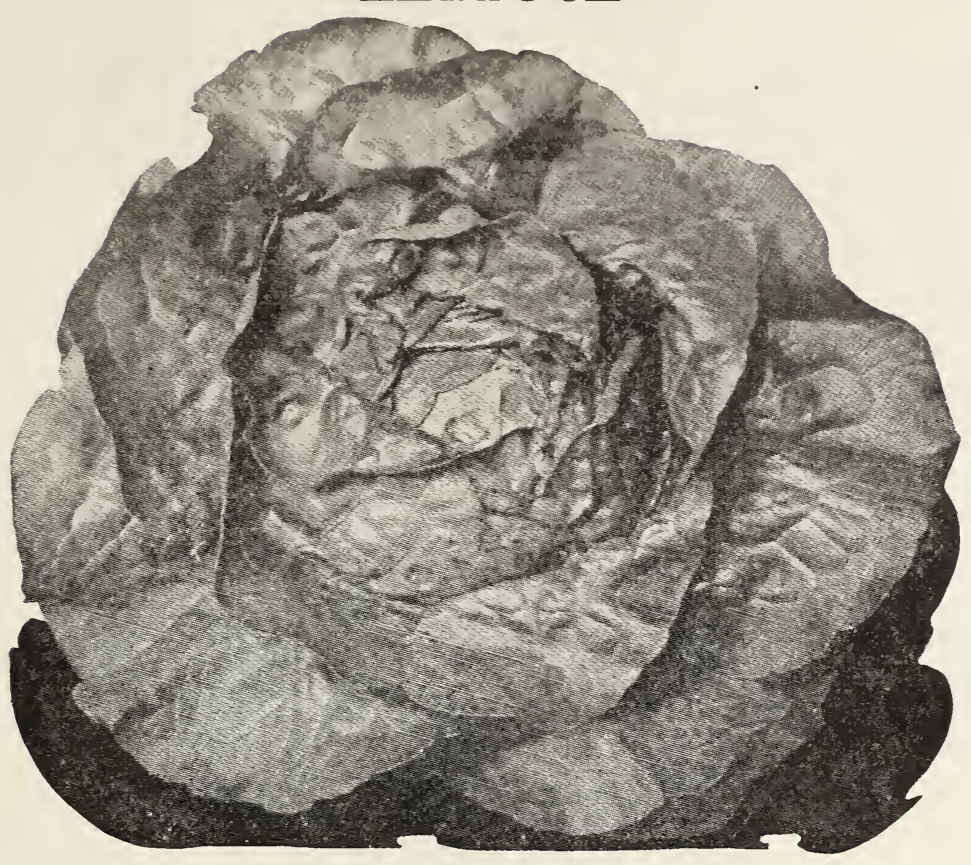

Lettuce, W. S. C. Ocoee.

One ounce will produce 2500 plants; 8 ounces enough plants to set out an acre.

W. S. C. Big Boston Williams' Double Rogued Stock. The W. S. C. Big Boston Double proven to be popular in all. Lettuce stock is a wonderful selection of Big Baston Lettuce and has W. S. C. Big Boston is well adapted for Spring and Fall culture, also for forcing in cold frames. Hundreds of acres of it are grown during the Winter in Florida and southern states for shipping to the northen markets; in every state it is wonderfully popular. Pkt., 10c; 0z., 25c; 1/4 lb., 75c; 1b., $\$ 2.50$, postpaid.

New Head Lettuce "Ocoee" Without a doubt this new head Lettuce is probably the without the reddish brown tinge, the outside leaves of recent introductions. It resembles Big Boston ducing a large, well formed, solid, crisp, perfect head. Ocoee is five days earlier than Big Boston and has very few outside leaves, resists the heat, also cold, better than any other variety of Lettuce. Ocoee is slow to bolt into seed stalk, the heads remaining on the field in first class merchantable condition ten days or two weeks longer than any other variety. All of our Lettuce customers $\mathbf{2 y}$ the Ocoee is the best heading variety. Pht., 15c; oz., 45c; 1/4 lb., \$1.50; lb., \$5.00, postpaid.

New York or Wonderful This is a decidedly crisp cabbage-heading variety. It is hot, dry weather, is very slow to run to seed, and is a sure header under most trying conditions. The solid heads often measure 15 inches across. The leaves are broad, fairly blistered, crumpled and twisted, thick, stiff and coarse in appearance and very flatly and tightly overlap one another. The color of the outer leaves is a dull, very dark green and the interior blanches creamy white, is crisp, tender and of good quality. Not recommended for forcing but very fine for a main Summer crop, and one of the best for shipping. Pkt., 10c; oz., 25c; 1/4 lb., 75c; lb., \$2.50, postpaid.

BIG BOSTON. Color, light green, slightly tinged reddish brown. Very popular. Pkt., 10c; oz., 15c; $1 / 4$ lb., $45 \mathrm{c}$; lb., $\$ 1.50$, postpaid.

HANSON. A curled sort making well blanched folded heads. Plt., 10c; oz., 20c; 1/4 lb., 50c; lb., $\$ 1.75$, postpaid.

ICEBERG. A large late crisp cabbage heading variety. Plkt., 10c; oz., 15c; 1/4 lb., 45c; lb., \$1.50, postpaid.

MAY KING. A handsome small extremely early variety. Plt., 10c; oz., 15c; 1/4 lb., $45 \mathrm{c} ; 1 \mathrm{~b} ., \$ 1.50$, Dostpaid.

CURLED VARIETIES.

BLACK SEEDED SIMPSON. One of the best and most popular loose-heading varieties. Pkt., 10e; oz., $15 \mathrm{c} ; 1 / 4 \mathrm{lb} ., 45 \mathrm{c} ; \mathrm{lb} ., \$ 1.50$, postpaid.

EARLY CURLED SIMPSON. A leading early loose heading variety of fairly large size. Pkt., 10e; oz., $15 \mathrm{c}$; $1 / 4 \mathrm{lb} ., 40 \mathrm{c}$; lb., $\$ 1.25$, postpaid.

GRAND RAPIDS. The favorite loose-leaved forcing lettuce. Pkt., 10c; oz., 15c; 1/4 lb., 45c; 1 ., \$1.50, postpaid.

PARIS WHITE COS. (Romaine). The finest for Summer use; the leaves should be tied up to blanch. Pkt., 10c; oz., 20c; 1/4 lb., 50c; lb., \$1.75; 10 lbs., \$15.00, postpaid. 
One ounce will sow 50 bills: 2 lbs. per acre.

W. S. C Bottom] This Melon is becoming more popular every year among the market vines of most early varieties have died. It is a very heavy yielder and has all the good qualities of the Rocky Ford. It is lightly later than the Rocky Ford, but a much sweeter Melon. Has mall seed cavity well netted, widely ribbed, and for shipping it is unexcelled. Ideal for hipping or hom market. Pkt., $10 \mathrm{c}$; 0z., 25c; $1 / 4 \mathrm{lb} ., 75 \mathrm{c}$; Ib., $\$ 2.50$, postpaid.

Rocky Ford Light green and of excellent flavor with a small seed cavity. Small, round, Pla smooth and heavily netted. Excellent shipper and one of the most popular sorts. Plkt., 10c; 0z., 15c; $1 / 4$ lb., 30c; lb., $\$ 1.00$, postpaid.

NEW KNIGHT. An extremely early medium sized melon. Fruit oblong, well ribbed and netted. The

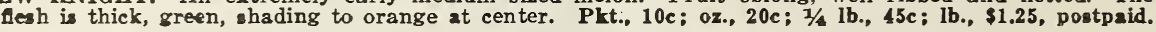

JENNY LIND. An extra early small green-fleshed melon deeply ribbed and heavily netted. Prt., 10c: a., 20 : : $1 / 4$ lb., 45 ; lb., $\$ 1.25$, postpaid.

PALLOCK 10-25. A rery popular standard Rocky Ford shipping melon, salmon tinted flesh. Pkt., 10c; ox., 20e: 1/4 lb., 50c: 1b., \$1.50, postpaid.

HEARTS OF GOLD. A splendid mall mid-season variety. Flesh very thick, deep salmon eolor. Plt., 10c; 0z., 20c; $1 / 4$ lb., 50e; 1b., \$1.50, postpaid.

MMERALD GEM. Fruits deep emerald green in color. Flesh very thick and of deep, rich almon color. Plt., 10c; 0z., 20c: 1/4 lb., 45e; lb., \$1.25, postpaid.

OSAGE or MILLERS CREAM. Flesh very thick deep salmon and of finest quality. Pkt., 10c; •z., 20e; 3/4 lb., 50c; lb., \$1.50, postpaid.

FORDHOOK. A medium sized melon. Flesh thick orange-yellow in color and of excellent quality. Pkt., 10c: oz., 20c; 1/4 lb., 50c; lb., \$1.50, postpaid.

\section{WATERMELON}

W. S. C. Whurmond Gray Thurmond Gray has permanently taken its place amons the (a) shipping varieties of Melons. It grows to a large size, is very 作 arm, will not break when sliced. Color of the rind is greenish gray. We consider the Thurmond Gray one of the best market sorts and recommend it to both market gardeners and large growers of Watermelons. Plt., 10c; oz., 15c; $1 / 4$ lb., 30c; lb., $\$ 1.00$, postpaid.

Stone Mountain A new round Watermelon showing light ribs or lobes like a cantaloupe. fhe color of the smooth skin is light green. The flesh is a uniform beautiany white hearts or stringiness. The average fruit weigh about $15 \mathrm{lbs}$. The rind is too tender to permit long distance shipping, but for the garden or local markets it has no equal. It is very prolific and exceptionally sweet. Pkt., 10c; oz., 40c; $1 / 41$ lb., $\$ 1.00 ; 1 b ., \$ 2.50$, pestpaid.

Wondermelon This flne new Watermelon has been rery popularly received. For a long time South old variety, Kleckley Sweet, has been the standard home garden Melon in the lar all over the country. It is not as good as it once was but at its best it could not compare with this fine new variety. This new Melon is regular in shape, larger, weeter, of better quality and better in every way than the old Kleckley. It is large, heavy, oblong, an even dark green skin, rather thin rind, rich bright scarlet flesh and an all-around ane Melon for home and nearby market use. Pkt., 10c; 0z., 15c; $1 / 4$ lb., 45c; lb., $\$ 1.50$, postpaid.

IRISH GRAY. Seeds white, fruit long, oval, gray, flesh bright red. Pkt., 10c; ox., 15c; 1/4 lb., 80e; lb., $\$ 1.00$, postpaid.

EXCEL. Largest of the shipping melons, mid-season. Fruit long dark green with faint stripe. Plt., 10c: 0z, 15c; 1/4 lb., 30c; lb., $\$ 1.00$, postpaid.

MPROVED TOM WATSON. One of the best main crop sorts, grows to rery large sixe. The dark green rind is a contrast to the bright scarlet flesh. Plt., 10c; oz., 15c; $1 / 4$ lb., 20c; lb., \$1.00, postpaid.

PERFECTION. This melon grows to an enormous size, the fruits weighing from 50 to 75 pounds. The rind is a glosey dark and flesh a dark red. Pkt., 10c; 0z., 15c; 1/4 Ib., 30c; lb., \$1.00, postpaid.

FLORIDA FAvORITE. Oblong in shape and grows to a fair size. Quality excellent. Pkt., 10c: es., $15 c$; $1 / 4$ lb., 30c; lb., $\$ 1.00$, postpaid.

MPROVED KLECKLY SWEET. Oblong in shape, slightly tapering towards tem end. Fleah very bright rich red. Plt., 10c; 0z., 15c; 1// lb., 30c; lb., \$1.00, postpaid.

HALBERT HONET. Oblong, skin dark green, medium early and fairly large tesh crimoon and rery sweet. Plt., 10c; oz., 15c; $1 / 1$ lb., 30c; lb., \$1.00, pestpald. 


\section{PEPPERS}

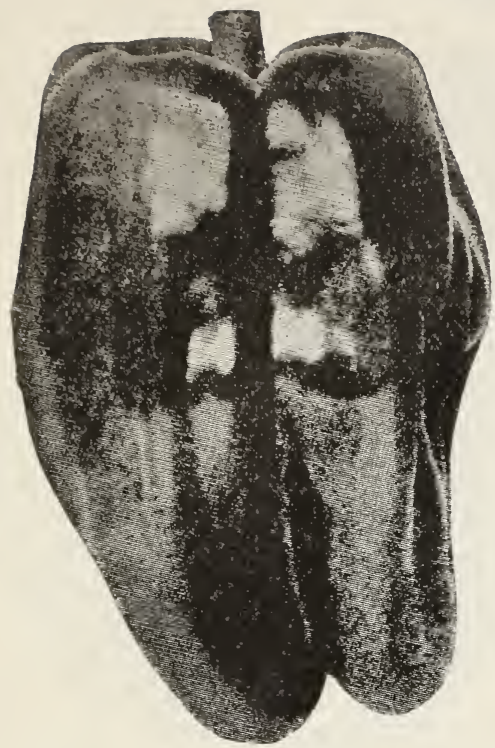

Pepper, W. S. C. Norfolk Ruby.

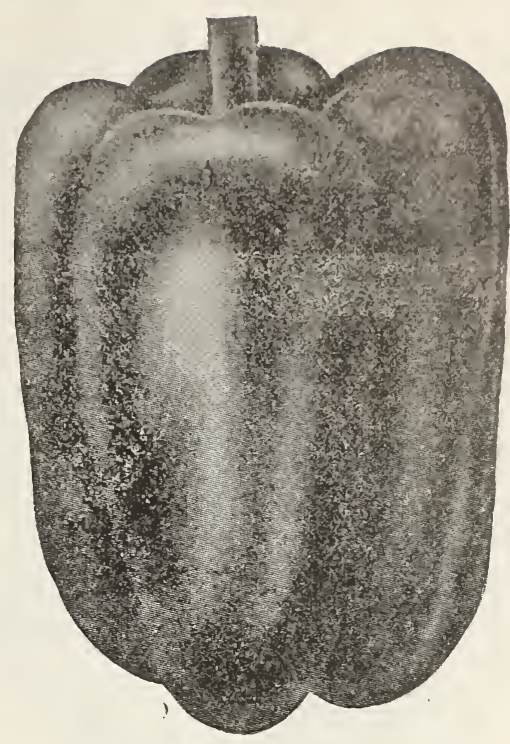

Pepper, W.S. C. Worldbeater.

one ounce of soed produces about 1000 plants. offer.

All our pepper seed are true American grown-we have no cheap pulp mill or imported stocks to

W. S. C. Norfolk Ruby Developed from the original type of Ruby King. While it is a especially call the attention of the trucker or shipping market gardener to its regularity of size and shape, making it an exceptionally desirable variety for good packing and fine appearance on arrival in the markets. This insures its being a top price seller at all times. It is very prolific, bright and glossy, of large size; the flesh is mild and thick and the lobes well filled out. It runs remarkably true to type and uniformity of size for a Pepper, and the plants are of strong, stocky, erect growth. Plt., 15c; oz., 65c; 1/4 lb., \$2.25; lb., \$8.00, postpaid.

W. S. C. World Beater It is a cross between Chinese Giant and Ruby King, having the .S. C. World Beater shape of the Ruby King, except that it is broader at the pointed end and almost the size of the Chinese Giant. It is far more prolific than Chinese Giant, some plants producing as high as twenty-four marketable Peppers, and it is fully as early as Ruby King. A Pepper we thoroughly recommend. Pkt., 15c; 0z., 65c; $1 / 4 \mathrm{lb} ., \$ 2.25 ; 1 \mathrm{~b} ., \$ 8.00$, postpaid.

CHINESE GIANT. One of the very largest of mild red varieties. Pkt., 10c; oz., 60c; 1/4 1b., \$1.85; lb., 87.00 , postpaid.

CHEESE. Noted for its sweetness. Pkt., 10c; 0z., 50c; $1 / 41 b ., \$ 1.75 ; 1 b ., \$ 6.00$, postpaid.

HARRIS EARLY GIANT. Of dwarf compact growth. Fruit scarlet, 5 inches in length by $31 / 3$ inches in diameter. The earliest large sweet pepper. Pkt., 10c; oz., 40c; 1/4 lb., $\$ 1.10 ; 1 b ., \$ 4.50$, postpaid.

RUBY KING. The fruit is large, bright glossy red and flesh sweet and mild. Pkt., 10c; 0z., 40c; $1 / 4$ lb., $\$ 1.40$; lb., $\$ 5.00$, postpaid.

WORLDBEATER. One of the best of the large peppers. Very productive and a good shipper. Plt. $10 \mathrm{c} ; 0 \mathrm{z} ., 40 \mathrm{c} ; 1 / 4 \mathrm{lb}$., $\$ 1.40 ; 1 \mathrm{~b} ., \$ 5.00$, postpaid.

RUBY GIANT. A variety of desirable size and shape for stuffing. Pkt., 10c; oz., 40c; 1/4 1b., \$1.40; lb., $\$ 5.00$, postpaid.

FLORIDA QUEEN. A new sweet pepper of the Ruby King type. Pkt., 10c; 0z., 40c; 1/4 1b., \$1.30; lb., $\$ 4.75$, postpsid.

ROYAL KING. Very eimilar to Ruby King but not as large. Plat., 10c; oz., 40c; 1//4 1b., 81.30; lb. \$.75, postpaid.

PIMENTO. A very thick fleshed, heart shaped smooth mild crimson variety. Plt., 10c; oz., 40: K/ lb. \$1.25; lb., \$4.00, postpaid.

LARGE BELL or BULLNOSE. A large early bright red variety of mild flavor, a favorite for stuffing when green. Pkt., 10c; 0z., 10c; $1 / 4$ lb., $\$ 1.25$; lb., $\$ 4.00$, postpaid.

ANAHEIM CHILI. A hot pepper, five to six inches long by one inch thick at stem, tapering to a point. Pkt., 10c; cz., 50c; $1 / 4$ lb., $\$ 1.75$; lb., $\$ 6.00$, postpaid.

LONG RED CAYENNE. This is the true Cayenne Pepper. Pkt., 10c; oz., 40c; 1/4 lb., $\$ 1.40 ; 1 b ., \$ 4.50$, postpaid.

RED CHILI. Fruit bright red and very hot. Used for pepper sauce. Pkt., 10c; 0z., 40c; 1/4 1b., \$1.25; lb., \$4.00, postpaid. 


\section{TOMATOES}

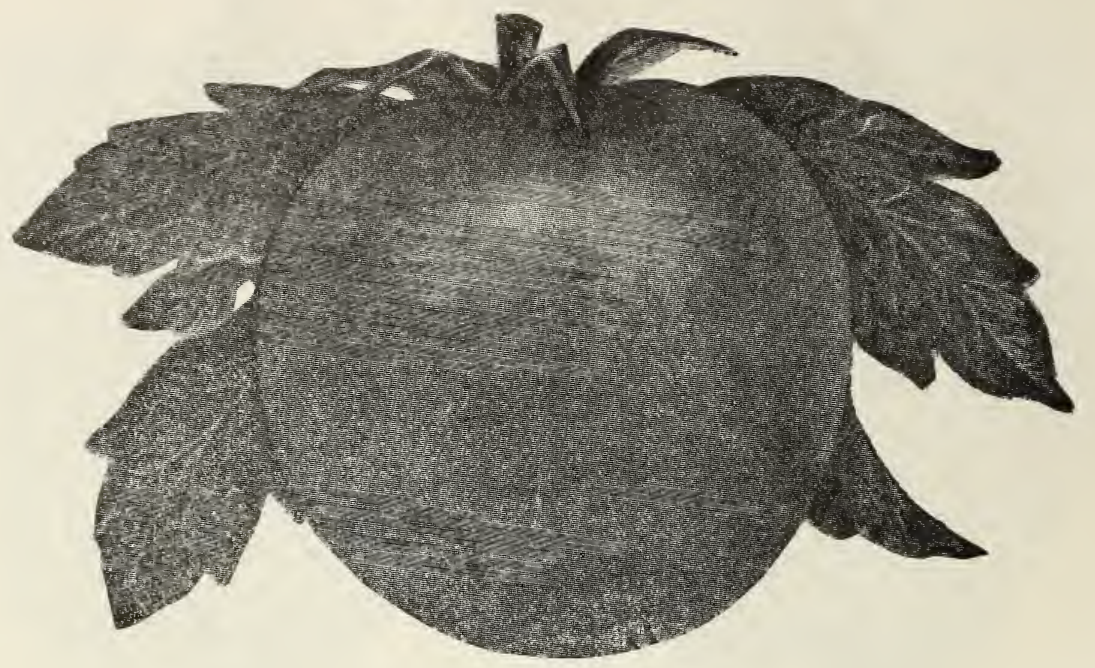

Tomato, Bryan's Self Topper.

One ounce will make about 1500 plants; 4 ounces will make plants enough for an acre. WE ARE TOMATO SEED SPECIALISTS

All our Tomato Seed is saved from fields that have been carefully rogued, hand selected and cannot be compared with cheap canning stocks.

\section{METHOD OF OPERATION}

In order to insure purity we grow each variety in a locality by itself. The ripe tomatoes of each variety are delivered to a central and convenient point for that particular sort, where, after careful inspection and the final rejection of undesirable types, all the seeding, curing and cleaning are done by experienced men.

Bryan's Self-Topper This Tomato is by far the smoothest, largest, most productive and quantities of perfect, solid Tomatoes. Five to ten days earlier than Globe. Very smooth, ripening from inside out, most delicious flavor. Vine growth very much the same as Bonny Best and growth comparing favorably with Globe. Resists wilt, blight and other Tomato diseases better than other varieties. Bryan's Self-Topper Tomato in habit of setting fruit and color is similar to Globe, setting the fruit in clusters at every joint to the tip end of the vines. Bryan's Self-Topper fruit is a purplish red, thick, smooth, small seed cavity, with less seeds than any other variety. Fruit firm, medium to large in size, superior quality, unusually heavy and continuous bearer throughout the season. Fine keeper and shipper-no cracking or bursting in transportation. Will stand shipping to much longer distances than any other variety. Pkt., 20c; oz., \$1.50; 1/4 lb., \$5.50; lb., \$20.00, postpaid.

W. S. C. Special Globe This is an improved stock of Williams' Selected Globe which has Bhort-jointed vines are vigorous and very productive. The Tomatoes mature a little earlier than most main crop varieties. The fruit is borne in ciusters, average large, though a little uneven in size and are nearly round or globe-shaped. Some a little elongated. They are smooth-ripen up thoroughly and are of a glossy purplish rose color; flesh firm, have few seeds, and are of mild flaror. A good keeper and shipper. Pkt., 15c; oz., 75c; 1/4 lb., $\$ 2.75$; lb., $\$ 10.00$, postpaid.

SELECTED GLOBE. A vigorous, productive medium early tomato, very popular with southern truckers. Fruit globe-shaped, smooth and solid, color purplish pink. Pkt., 10c; cz., 50c; 1/4 lb., \$1.75; lb., \$6.00, postpaid.

EARLY DETROIT. A large purple tomato. A good shipper and suitable both for early and main erop. Pkt., 10c; 0z., 40c; $1 / 4 \mathrm{lb} ., \$ 1.10$; lb., $\$ 4.00$, postpaid.

JUNE PINK. The best extra early purple. Pkt., 10c; oz., 40c; 1/4 lb., $\$ 1.25 ; 1 b ., \$ 4.50$, postpaid.

BONNY BEST. A good early red skinned variety for all purposes. Pkt., 10c; oz., 40c; 1/4 lb., $\$ 1.10$; lb., $\$ 4.00$, postpaid.

CHALKS EARLY JEWEL. An exceptionally fine early variety about ten days later than Earliana. Pkt., 10c; oz., 40c; 1/4 lb., \$1.10; lb., \$4.00, postpaid.

EARLIANA. A popular extra early red of good size. Pkt., 10c; oz., 40c; 1/4 lb., $\$ 1.10 ; 1 b ., \$ 4.00$, postpaid. JOHN BAER. An early productive red tomato. A popular market sort. Pkt., 10c; 0z., $40 \mathrm{c} ; 1 / 41 \mathrm{~b} .$,
$\$ 1.10 ; \mathrm{lb} ., \$ 4.00$, postpaid.

PONDEROSA. An extra large deep purple tomato. Pkt., 10c; oz., 50c; 1/4 lb., \$1.75; lb., $\$ 6.00$, postpaid. 


\section{TOMATOES}

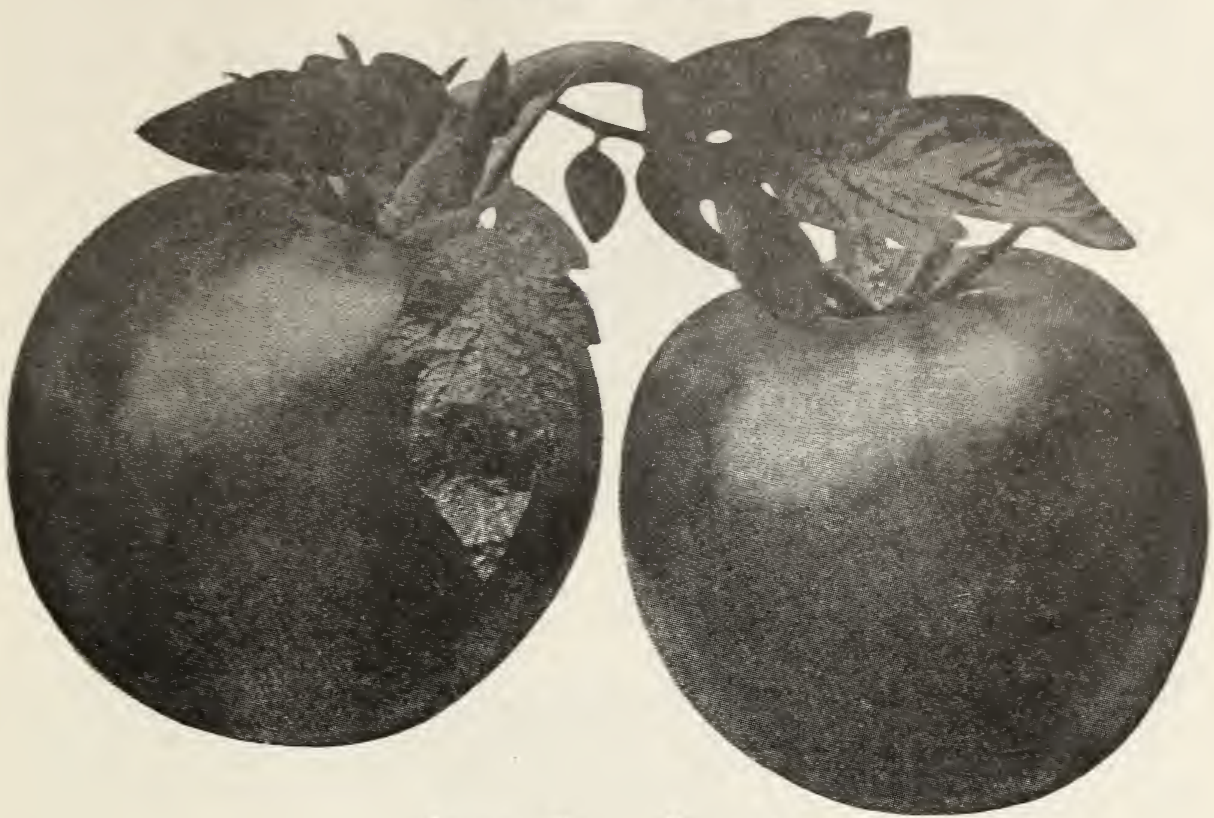

Tomato, W. S. C. Marglobe.

\section{Marglobe}

This tomato was originated and introduced by the U. S. Department of Agriculture through the efforts of Dr. F. J. Pritchard of the Bureau of Plant Industry, and it has gained great popularity in southern Florida owing to its resistance of wilt, nailhead rust and its wonderful yielding qualities. The Marglobe is also in great demand among the canning trade in all parts of the country.

In color this tomato is a beautiful scarlet fruit, deep globe shape, setting in clusters in every joint of vine. Its splendid habit of growth is slightly greater than that of the Globe and should be grown on rows at such a distance making allowance for the increased vine growth.

As for rielding qualities it is equal to that of a good selection of Globe, but is about a week to ten days later. To get the best results from the Marglobe we recommend frequent applications of fertilizer and we beliere any gardener or tomato grower wanting a medium early tomato, the Marglobe will prove most satisfactory wherever used. Plt., 10c; oz., 75c; 1/4 lb., \$2.25; lb., \$8.00, postpaid.

W. S. C Marglobe An extra fine selection of the above. Fruits are large, smooth and Ib., $\$ 10.00$, postpaid.

Cooper's Special A new second early variety. Vines sturdy and rigorous growing, prosize, globe-shaped, light purplish pink color, solid, meats and of excellent flavor. A most maluable ort for southern shippers and market growers and equally desirable for the home garden. Vine about 3 feet tall, vielding heavier than dwarf sorts and more compact than tall rarieties. Pkt., $10 \mathrm{c}$; oz., 50c; $1 / 4$ lb., $\$ 1.75$; 1 b., $\$ 6.00$, postpaid.

Florida Special Is a large, round Tomato; deep red; fine flavor; skin firm; meat solid; very sirable for canning and wroductive, and a few long-distance shipping. It is suitable for both early and main crop. Pkt., 10c; 0z., 35c; 1/4 lb., $\$ 1.00$; lb., $\$ 3.50$, postpaid.

Gulf State Market This Tomato is a winner and was dereloped out of the Eariy Detroit, Gulf State Market and retains the earliness of that variety. The vines are very vigorous and withstand blight wonderfully well. The fruit sets well over the vine and is large for so early a variety. Round or about globe shape. Shows but little depression about the stem and bloom end, smooth and free from cracks. Color deep purplish, ripening well about the stem. The skin is firm and the flesh solid. Has proven to be the most productive of all shipping Tomatoes. It is desirable for late crop as well as early. Pkt., 10c; oz., $45 \mathrm{c} ; 1 / 4 \mathrm{lb}$., $\$ 1.50$ : lb.. 35.00 . Dostpaid. 


\section{SQUASH}

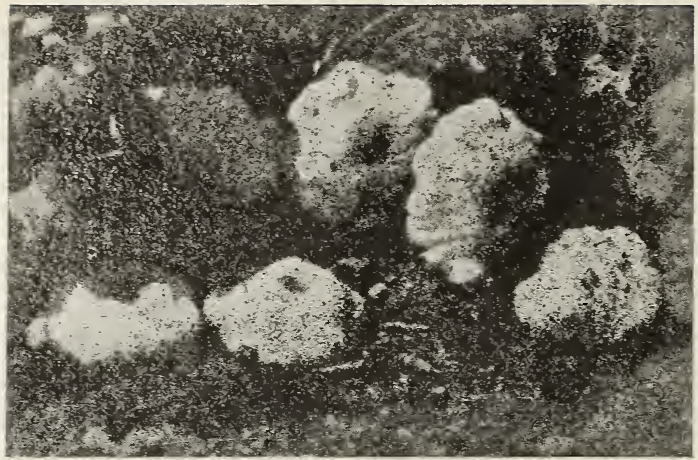

Squash, W. S. C. White Bush.

One ounce of the bush varieties to 40 hills; 2 to 3 lbs. to the acre.

One ounce of the large-seeded varieties to 15 hills; 3 to 4 lbs. per acre.

W.S.C. Extra Early White Bush $\begin{gathered}\text { This well known popular variety has always } \\ \text { been difficult to fix and large field plantings }\end{gathered}$ have always been likely to show a large percentage of inferior fruit, striped and cup-shaped types. The W.S. C. selection is as round as a good size saucer, quite flat, very much scalloped, about ten days earlier than the old type White Bush Squash, and the plant is of medium bush form with fruits borne in clusters at the base. It does not require so much space as is demanded by most Squashes. Pkt., 15c; cz., 30c; 1/4 lb., \$1.00; lb., \$3.00, postpaid.

Golden Yellow Summer Crookneck old well known crookneck variety for home bright orange-yellow color and covered with warty fine desirable for its rich, buttery flavor. We consider this 40c; lb., \$1.25, postpaid.

BOSTON MARROW. An early Fall sort of oval form; skin thin and when ripe a light orange color. Good size, excellent keeper. Plt., 10c; 0z., 15c; $1 / 4$ lb., $40 \mathrm{c}$; lb., $\$ 1.25$, postpaid.

CocozellE. Italian vegetable marrow, or green bush vegetable marrow. Pkt., 10c; ox., 15c; 1/4 1b., 45 ; lb., $\$ 1.50$, postpaid.

EARLY WHITE BUSH. The most popular of the white summer types of squash. Pkt., 10e; 0s., 15e; Y/4 lb., 35c; lb., $\$ 1.00$, postpaid.

GIANT SUMMER CROOKNECK. The best summer variety. Fruit is bright gellow and covered with warts. Pkt., 10c; 0z., 15c; 1/4 lb., 40c; lb., $\$ 1.25$.

TRUE HUBBARD. The most popular and widely used of the winter squashes. Fruit oblong and pointed, heavily warted, dark green in color, with orange-colored flesh. Is remarkable for its keopins qualities. Pkt., 10c; oz., $15 \mathrm{c}$; $1 / 4 \mathrm{lb}$., $40 \mathrm{c}$; lb., $\$ 1.25$, postpald.

\section{PUMPKIN}

One ounce is sufficient for a row of 100 feet in hill, 3 to 4 lbs. per acre.

CHEESE. The most popular for pies and table use; large, flat-round; creamy yellow skin; thick orange flesh of fine quality; a splendid keeper. Pkt., 10c; 0x., 15c; 1/4 lb., 30c; lb., 85e, postpaid.

CONNECTICUT FIELD. A productive, large, orange colored field Pumpkin, usually grown for stock feeding, but it also makes good pies. Pkt., 10c; 0z., 15c; 1/4 1b., 25c; lb., 75c, postpaid.

GREEN STRIPED CUSHAW. Fruits very large, with crooked neck; color creamy white, irregularly striped or traced with green; flesh light yellow, very thick, sweet. Very productive and popular in the southern states. Pkt., 10c; 0z., 20c; 1// lb., 10c; lb., \$1.25, postpaid.

KENTUCKY FIELD. A large variety, producing Pumpkins in abundance. Has thick meat of $1 \mathrm{ne}$ quality. Very suitable for canners' use. Pkt., 10c; 0z., 15c; 1/4 lb., 25c; lb., 75c, postpaid.

KING OF THE MAMMOTHS. Extremely large, orange colored, often weighing 50 pounds. Round. Plt., 10c; 0z., 20c; 1/4 lb., 50c; lb., \$1.50, postpaid.

SUGAR or PIE. A handsome and productive small Pumpkin, 10 to 12 inches in diameter; roundflattened; skin orange, flesh deep yellow, fine grained and very sweet. Pkt., 10c; 0r., 15c; 1/4 lb., 30c; lb., $\$ 1.00$, postpaid. 
Mary Washington. Seed. The best all-round variety

Postpaid

Mery Washington. Roots. Per 100, $\$ 2.25$; per 1000, $\$ 15.00$.

Prt.

Oz. $1 / 4 \mathrm{lb}$.

$.10 \quad .20 \quad .60$

Lb. 2.00

\section{BRUSSELS SPROUTS}

Half-Dwarf Perfection. Plants about two feet high, well covered with sprouts

Long Island Improved. Plant earlier, more dwarf and compact than other varieties. We consider it the most dependable...

\section{COLLARDS}

North Carolina Short-Stem. Has a very short stem, with large, spreading leaves; very hardy, and yields good returns
True Georsia. A well-known standard sort, and the one most generally used in the South.

Cabbaging. Dwarf stalk. Large dark green leaf.

Green Glaxed. A distinct glossy, dark green, long shell-shaped leaf, re sisting cold as well as with tanding the summer heat, tender and well flavored

\section{CHICORY}

Large-Rooted or Cofieo.

Witloof, or French Endive. Esteemed as a salad plant

\section{KOHL RABI}

A bulbous-formed regetable; when cooked, before fully grown is tender and excellent, combining the fiavors of Cabbage and Turnip.

Early Purple Vienna. The outside color is purple; flesh white and delicate

Large White Vienns. Large, quick-growing, greenish-white skin and tender white flesh

\section{LEEK (1 oz. will sow 100 feet of drill)}

American Flag. Strong, vigorous growth, excellent for the market gardener

Monstrous Carentan. Hardy and productive.

\section{PARSLEY (1 oz. for 150 feet of drill)}

Extra Double Curled. Vigorous, compact, growing variety

Champion Moss Curled. Densely curled, dark green leaves; beautiful for garnishing; a very select and productive stock

W.S. C. Green Marvel. A compact and exquisitely curled variety. Very decorative of a rich deep green color

Plain. The leaves are not curled; plant very hardy

Hamburg-Rooted. Grown for the root which resembles a parsnip in shape and color

\section{PARSNIP ( $1 \mathrm{oz}$. for 200 feet of drill)}

Improved Hollow Crown. The best all-round variety of parsnips. .10

PEAS (2 lbs. to 100 feet of drill. 90 to $150 \mathrm{lbs}$. to an acre)

Blue Bantam. A splendid large-podded dwarf variety of the Laxtonian

class or Prosperity. The most popular of the long, large-podded wrinkled Peas

Laxtonian. One of the earliest dwarf Peas. Vines are vigorous, growing about eighteen inches high, well covered with large, even-sized pods averaging 8 to 9 to a vine and 9 to 10 peas in a pod. Quality of the best

Little Marvel. An extra fine dwarf sweet pea

Telephone Dwarf. One of the most productive of the large-podded wrinkled sorts

Telephone Tall. A standard high quality large-podded pea

straight, square-ended, dark green pods, containing 7 to 8 large, richflavored, deep green peas. Almost as early as the extra early smooth peas

W.S.C. New Era. Somewhat similar to Gradus but earlier. Pods a shade darker

Nott's Excelsior. This is an extra early dwarf wrinkled pea, usually ready for table in 40 to 45 days from planting. It grows about 14 inches high

Postpaid Not prepaid

Plt. Lb. $10 \mathrm{lbs} .100 \mathrm{lbs}$. 
Cincinnati Market. Similar to Long Scarlet Short Top, but a deeper red in color and remains a little longer in condition for use

Early Long Scarlet Short-Top. Roots are smooth, slender, uniform in shape and of attractive bright red color. Grows about one-third out of the ground, and continues tender until matured

Early Scarlet Globe. One of the most desirable Radishes for field culture. It is very attractive in both shape and color, being a bright, transparent red and very smooth skinned

Early Scarlet Turnip White-Tipped. A very handsome Radish, bright red with the exception of the tail which is pure white

Long White Icicle. One of the best early long white sorts, suitable either for forcing or growing outside

White Box. An almost globe-shaped sort, slightly flattened, with pure white skin and crisp flesh. Unlike most other early sorts, it remains in fine table condition until quite overgrown. Ready in from 35 to 40 days

White Strasburg. One of the most popular sorts. Color white. It remains olid a long time after reaching maturity

Oz.

.10

.10

.10

.10

.10

.10

.10

.25

.25

RHUBARB or PIE PLANT (1 oz. seed sufficient to sow

100 feet of drill. About $10 \mathrm{lbs}$. for one acre)

Myatt's Victoria Seed. The best Rhubarb for the South

Rhubarb Roots, Victoria. Extra large divided roots. Each, 15c; doz. $\$ 1.50$; per 100 , $\$ 6.50$.

\section{SALSIFY, or OYSTER PLANT (1 oz. to 75 feet of drill)}

Mammoth Sandwich Island. Tender and delicious. Superior to all other sorts

\section{SORREL}

Large-Leaved French. The best of the Garden Sorrels; large, pale green leaves of mild, acid flavor; esteemed as salad, cooked as "greens," etc....

\section{SPINACH (1 oz. for 100 feet of drill)}

Virginia Savoy Blight Resistant. This is a blight resisting strain of Savoy introduced by the Virginia Truck Experiment Station at Norfolk, Va.

Bloomsdale Savoy. A valuable variety which is extensively grown; producing large crops. Very early and hardy; one of the best for market and canning. Plants of upright growth, leaves of medium size, more or less crumpled or blistered; colored glossy medium green

New Zealand. Thrives during the hot weather in any soil. The tender shoots are of good quality and may be cut throughout the Summer. Plant three or four seeds in a hill two feet apart each way.

\section{TURNIP (1 oz. for 150 feet of drill) White-flesh varieties.}

Ox.

Early White Flat Dutch. A standard early, white flat Turnip; an excellent garden variety; flesh white and mild

Early Purple Top Milan. One of the earliest Turnips in cultivation; medium-sized, flat, smooth, white flesh and skin, with purple top--It is used largely at that season for bunching. It grows rapidly; is flatround in shape, with very small leaves, and slender stems. Both skin and flesh are pure white

Purple Top Strap Leaf. This is the true strap-leaved flat-rooted sort, and a very fine stock. It is even in size, regular in shape, and the color strongly marked. The upper side of the root is purple; the lower white

Long White, or Cowhorn. A long, white-fleshed Turnip, growing half above ground; although large, it is of fine quality.

Purple Top White Globe Turnip. An early variety very much in favor with the market gardeners. Of globe shape, heavy cropper; skin white with purplish top. Superior quality either for table use or for stock......

Pomeranian White Globe, or Large White Norfolk

Beven Top. Used only for greens

Southern Prize. A good salad variety.

White Egg. White, shaped oval like an egg

YELLOW-FLESHED VARIETIES.

Golden-Ball, or Orange Jelly. Medium size, globe-shaped roots; very early; flesh golden-yellow, of fine texture and sweet

RUTABAGA. Russian or Swedish Turnips.

Amorican Purple-Top. This is the best and most popular table variety.-. 


\section{WILLIAMS' FAMOUS LAWN GRASS MIXTURE}

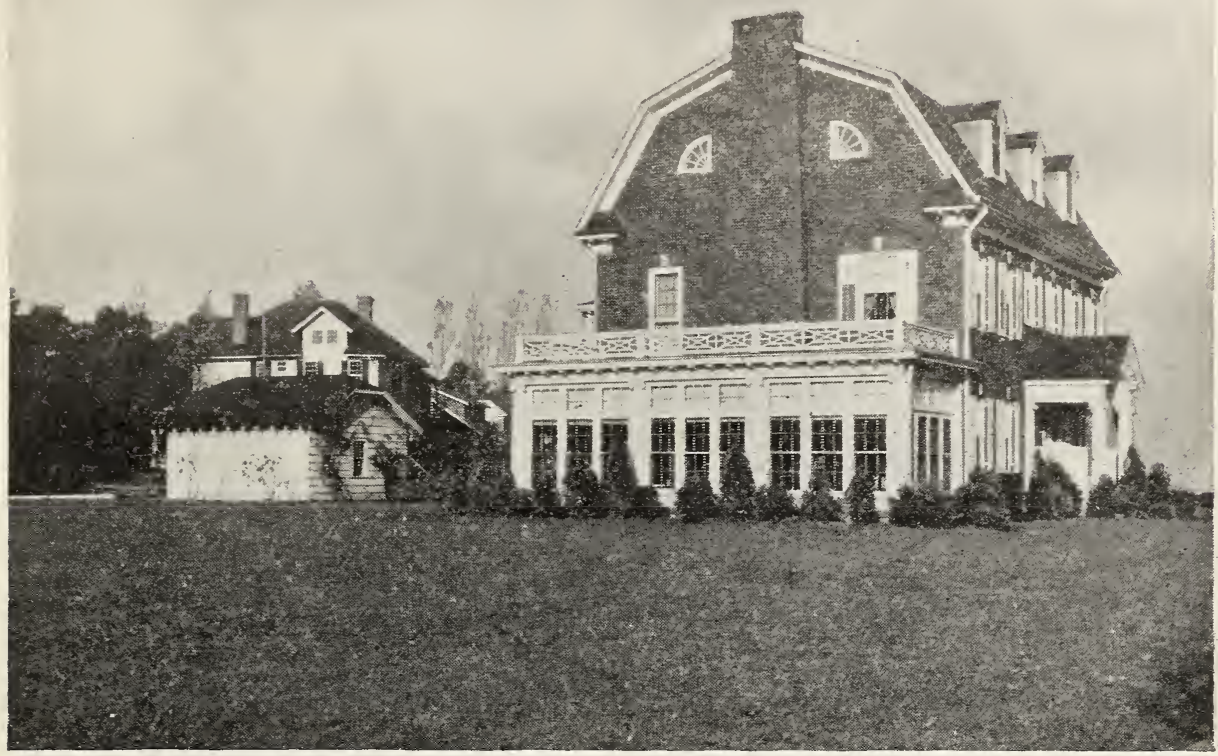

The essentials for a fine lawn are: First, a rich, well drained soil; second, careful preparation of the ground, making it as fine and smooth and mellow as possible; third, wise selection of seeds; fourth, sowing at such time as to give the young plants a chance to become well established before being subjected to very dry or cold weather or to the direct rays of the hot summer sun. However much care is bestowed on the soil and seed, no lawn will be beautiful without frequent mowing and rolling. Too much care cannot be bestowed upon the selection of grasses, as some varieties are the most luxuriant in the Spring, others in Summer, others again in Autumn and a combination of the proper sorts is required for a perfect, carpet-like lawn. It may be planted early in Spring or Fall and should be sown at the rate of 80 to 100 pounds per acre. If sown in the Spring, sow as early as possible, making the surface very fine and smooth, then raking it over and sowing the seed just before a rain, which, if the surface has just been raked, will cover the seed sufficiently. For Fall seeding sow, before the Autumn rains and early enough to enable the young grass to become well established before very cold weather, when a light dressing of manure should be given.

\section{WILLIAMS' EMERALD LAWN GRASS SEED}

This famous Lawn Grass Seed Mixture has been thoroughly tested and proved the best for our our southern climate. The seed should be sown thickly on newly raked or harrowed surface, covering with soil about one-quarter inch deep. This may be accomplished by raking the surface first in one direction and then in an opposite direction. When the raking is finished roll the ground thoroughly with a heavy iron roller. Williams' Special Fertilizer applied as a top dressing every few months will produce the much desired fine green surface. Sow $1 \mathrm{lb}$. to every 200 square feet; 100 lbs. to the acre. Price, 1 lb., 50c; 2 lbs., 95c; 5 lbs., \$2.25; 10 lbs., $\$ 4.25 ; 20$ lbs., $\$ 8.00 ; 100$ lbs., $\$ 35.00$, prepaid parcel post or express.
SHADY PLACE LAWN SEED, There is nothing more annoying in caring for a lawn than the bare, unsightly spots under the trees, shrubs, etc., and invariably all efforts have failed to get the grass to grow in such places; but, by sowing this mixture, the difficulties will be overcome. Price, 1 lb., 60c; 2 lbs., \$1.00; 5 lbs. $\$ 2.50 ; 10$ lbs., \$4.75; 20 lbs., \$9.00, postpaid.

WILLIAMS' LARCHMONT LAWN GRASS SEED. Undoubtedly the best results with the lawn depend upon the use of the proper grasses. Our formula comprises a well balanced blend of fine bladed and deep-rooting varieties which have given satisfactory results under the varied conditions of soils and climate. This mixture will produce a smooth, green, velvety sod. We include only sufficient clover to help thicken the bottom of the sod. Lb., \$1.00; 10 lbs., \$9.00; 100 lbs., $\$ 75.00$, prepaid.

WILLIAMS' SEASHORE MIXTURE. A mixture of fine grasses peculiarly suited to seaside lawns and with a liberal top dressing of Wilsco Humus will give excellent results. Lb., 50c; 5 lbs., $\$ 2.25 ; 10$ lbs., \$4.25; 20 lbs., \$8.00, prepaid.

TENNIS COURT MIXTURE. A mixture of grasses adapted for tennis courts, this formula will make a firm, green and lasting turf which will improve with trampling. 5 lbs., $\$ 3.50 ; 25$ lbs., $\$ 16.00$; 100 lbs., $\$ 60.00$, prepaid.

GOLF LINKS MIXTURE. We have made a special study of grasses especially adapted for golf links and the mixture we offer comprises only fine bladed varieties which will withstand frequent cutting and trampling. Prices on application.

WHITE CLOVER-White Dutch or Lawn Clover (Trifolium Repens). This is valuable for pasturage as well as for lawns; it succeeds where other clovers and grasses fail, and it seldom dies out. It can be sown at all seasons, although early Spring is best. Sow 10 to 12 lbs. per acre if alone, or 5 lbs. if sown with other crops. Oz., 10c; $1 / 4$ lb., $25 \mathrm{c}$; $1 / 2$ lb., $40 \mathrm{c}$; 1b., $75 \mathrm{c}$; 100 lbs., $\$ 60.00$ 


\section{WILLIAMS' RECLEANED GRASSES}

\section{PRICES ON FIELD SEED FLUCTUATE. WRITE FOR PRICES ON LARGE QUANTITIES.}

BERMUDA GRASS (Cynodon dactylon). A most valuable grass for the southern course. It grows on all types of soils and particularly land that is well limed. Sow 10 to $15 \mathrm{lbs}$. to the acre. Lb., 65c; 100 lbs., $\$ 55.00$. (Bu. 35 lbs.)

CARPET GRASS. One of the most valuable pasture grasses for the lower South. It grows on poor, sandy soils better than Bermuda and does well on most any soil with a fair amount of moisture. For lawns and golf courses it will make a heavy sod. Sow 10 lbs. per acre for pasture, twice this for lawns, from early Spring until July. Lb., 65c; 100 lbs., $\$ 55.00$.

CREEPING BENT. This is undoubtedly one of the finest grasses for putting greens. Does well on all soil, particularly on light, moist land. Sow 2 bushels per acre. Lb., 90c; 100 lbs., $\$ 80.00$. (Bu. 20 lbs.)

KENTUCKY BLUE GRASS (Poa pratensis). A true perennial, lasting indefinitely and improving every year. It succeeds well on all soils, especially where lime is used. It is frequently used on putting greens. Sow 3 bushels per acre. Lb., 60c; 100 lbs., $\$ 45.00$. (Bu. 14 lbs.)

ORCHARD GRASS (Dactylis glomerata). For early pasturing this is very desirable; also fine for sowing in shaded places. Sow 50 lbs. per acre. Lb., 40c; 100 lbs., \$28.00. (Bu. $14 \mathrm{lbs}$.)

PERENNIAL RYE GRASS (Lolium perenne). This variety is used in a mixture for fairways and where a quick turf is desired. It produces a verdant growth four or five weeks after sowing. Sow 3 bushels per acre. Lb., 30c; 100 lbs., $\$ 20.00$. (Bu. 24 lbs.)

RED TOP FANCY (Agrostis palustris). Red Top is a remarkable grass accommodating itself to a variety of soils and conditions. It grows well on wet land. It is strongly drought-resistant and flourishes on soils so very poor in lime that most other grasses fail. A valuable grass for fairways. Sow 1 bushel per acre. Lb., 40c; 100 lbs., \$30.00. (Bu. 32 lbs.)

ITALIAN RYE GRASS. Yields three or four cuttings a year of most nutritious hay; a very valuable grass, particularly adapted for rich, loamy soils or low grounds; does better in damp situations than most grasses. Recommended principally for Fall seeding. Sow 50 lbs. per acre. Lb., 30c; 100 lbs., \$20.00. (Bu. $20 \mathrm{lbs}$.)

SHEEP'S FESCUE (Festuca ovina). An excellent grass to grow on poor, sandy soils for fairways, when mixed with other grasses, as it helps to make a durable sward. For the "rough" on sandy, dry soil, it is excellent. Sow 2 bushels per acre. Lb., 55c; 100 lbs., \$40.00. (Bu. 14 lbs.)

SUDAN GRASS. A tall annual grass, growing 6 to 8 feet high when drilled, but when sown broadcast, thickly, does not grow quite so tall. Will produce more hay to the acre than any grass that has ever been introduced. Allows 3 to 4 cuttings, and produces 2 to 5 tons per acre, depending upon the soil. Can either be drilled at the rate of 2 to $3 \mathrm{lbs}$. per acre in 3 -foot rows or broadcast at the rate of 15 to 25 lbs. per acre. Plant from March to August. Lb., 20c; 10 lbs., $\$ 1.50 ; 100$ lbs., $\$ 10.00$, not prepaid. (Bu. 35 lbs.)
TIMOTHY. The most extensively grown hay grass. One-half bushel sows an acre. For hay, Timothy is the best known and most extensively grown of all grasses. Lb., 20c; 100 lbs., \$12.00. (Bu. 45 lbs.)

PERMANENT PASTURE AND HAY MIXTURE. A mixture of varieties which will form a permanent pasture that lasts for years. Composed chiefly of native and acclimated grasses, which have been found to be best. Sow on new land which has been plowed and harrowed, at the rate of 80 pounds per acre; on ground partly covered, about 40 pounds per acre. Lb., 40c; 100 lbs., $\$ 30.00$.

\section{CLOVERS}

ALFALFA or LUCERNE (Medicago sativa). The most valuable forage crop on the American farm today. It is sown during May, August and September, these being the best months for success, although it can be sown at other times with a possible chance of doing well. Careful preparation of the soil previous to sowing is the main thing. Sow not less than one bushel (30 lbs.) per acre, preferably with no other crop. Lb., 50c; 100 lbs., $\$ 40.00$.

ALSIKE or SWEDISH CLOVER (Trifolium hybridum). One of the best for mixing with timothy; it is perfectly hardy in every climate. Under ordinary conditions it grows from 1 to 2 feet high; it is sown early in the Spring or late Summer. It is as nutritious as red clover and is a valuable farm crop. Sow 10 to $15 \mathrm{lbs}$. per acre alone, or 8 lbs. per acre with timothy. Lb., 60c; 100 lbs., \$50.00.

BOKHARA CLOVER (Melilotus alba). A strong growing perennial of value for green manuring, especially South; also largely grown for the excellent food it affords throughout the season for bees. Lb., 25c; 100 lbs., \$18.00.

CRIMSON CLOVER (Trifolium incarnatum). Principally used for soiling or green manuring, for which purposes it is highly valuable. If desired for feed, cut it just before it flowers. Sow any time from April to October, the earlier the better, 20 lbs. per acre. If sown in early Spring it can be plowed down the first year. Late Summer or Fall seeding is usually practiced. It is not hardy for more than one season and must be sown each year. Lb., 25c; 100 lbs., $\$ 20.00$.

RED CLOVER, MEDIUM (Trifolium pratense). More widely known and used than any other: used principally for hay purposes. Height from 18 inches to $2 \frac{1}{2}$ feet. Sow early in the Spring or in late Summer-July and August; if alone, 20 lbs. per acre; if with other crops, 10 lbs. per acre. A Red Clover field can be cut twice a season. Lb., 60c; 100 lbs., $\$ 50.00$.

WHITE DUTCH or LAWN CLOVER (Trifolium repens). This is valuable for pasturage as well as for lawns; it succeeds where other Clovers and grasses fail, and it seldom dies out. It can be sown at all seasons, although early Spring is best. Sow 10 to $12 \mathrm{lbs}$. per acre if alone, or $5 \mathrm{lbs}$. if sown with other crops. $0 z ., 10 \mathrm{c} ; 1 / \mathrm{lb}$, 25 c; $1 / 2$ lb., 40 c; lb., 75 c; 100 lbs., $\$ 60.00$. 


\section{WILLIAMS’ FARM AND FIELD SEEDS}

Prices on Field Seed Fluctuate. Write for Prices on Large Quantities.

\section{SELECTED FIELD CORN}

Plant $\&$ to 10 quarts per acre in hills for shelled Corn or for silo; $11 / 2$ to 2 bushels broadcast for fodder.

BLOUNT'S PROLIFIC. On good land, especially on river low grounds, Blount's Prolific bears from 2 to 4 good ears to the stalk. Lb., 20c, postpaid...Pk. (14 lbs.), \$1.15; bu. (56 lbs.), $\$ 4.00$, not prepaid.

HICKORY KING. (See page 4.) Lb., 20c, postpaid. Pk. (14 lbs.), $\$ 1.00$; bu. (56 lbs.), \$3.50, not prepaid.

IMPROVED WHITE DENT. Improved White Dent has been the reliable old stand-by with southern Corn growers, and its merits are generally recognized. Lb., 20c, postpaid. Pk. (14 lbs.), \$1.00; bu. (56 lbs.), \$3.50, not prepaid.

LATHAM'S DOUBLE. (120 dars.) A heary sielding white grain Corn, rather a vigorous grower, full foliage, two well matured ears to the stalk. A high position attained both in official test and prirate planting. Lb., 20c, postpaid. Pk. (14 lbs.), \$1.15; bu. (56 lbs.), \$4.00, not prepaid.

NORFOLK MARKET. (See page 4.) Pkt., 10c; lb., 25c; 2 lbs., 45c, postpaid. Pk. (14 lbs.), $\$ 1.65$; bu. (56 lbs.), $\$ 6.00$, not prepaid.

TRUCKERS' FAVORITE. (See page 4.) Lb. 20 e, postpaid. Pk. (14 lbs.), \$1.50; bu. (56 lbs.), $\$ 5.60$, not prepaid.

SNOWFLAKE. The ears are large, the grains deep, it matures in about 100 days, and it nearly always carries two ears to the stalk. Lb., 20c, postpaid. Pk. (14 lbs.), 90c; bu. (56 lbs.), \$3.50, not prepaid.

VIRGINIA ENSILAGE. This continues to be one of the most satisfactory ensilage Corns, making a large growth of broad, thick, succulent fodder. Lb., 20c, postpaid. Pk. (14 lbs.), $85 \mathrm{c}$; bu. (56 lbs.), $\$ 3.00$, not prepaid.

W.S.C. VIRGINIA YELLOW DENT. (See page 4.) Lb., 20c, postpaid. Pk. (14 lbs.), $\$ 1.25$; bu. (56 lbs.), $\$ 4.00$, not prepaid.

\section{BUCKWHEAT}

Sow about the middle of June, broadcast, at rate of 1 bushel to the acre, or $1 / 2$ bushel in drills. JAPANESE. Earlier, more prolific and rields nearly double the weight per acre of other sorts. Lb., 20c, postpaid.

\section{KAFFIR CORN}

A great has and grain crop, produces 5 to 10 tons of has of the finest quality per acre. Greatly relished by all lire stock. Average field, 50 bushels per acre. Broadcast or drill 50 to $60 \mathrm{lbs}$. per acre. Lb., 20c, postpaid.

\section{COW PEAS}

THE SOLTH'S ECONOMICAL SOILIMPROVING AND HAY CROP

Of great soil-improving value, also making a fine, nutritious green forage or hay crop, enriching the soil when the crop is cut off. Should be sown from May to Juls, at rate of 11,2 bushels to acre, either broadcast or in wheat drills.

Prices on Corpeas continually fuctuate. Write for quotations.

BLACK. A standard variety, rery prolific and early maturing, making a large growth of vine and a heary vield of Peas. Fine also for forage. Lb., 20c, postpaid. Pk., \$1.25; bu., \$4.50, not prepaid.

EARLY, OR RAMSHORN BLACK EYE. Similar in growth of vine but making larger yield than Black Eye, and maturing quicker. Lb., $25 \mathrm{c}$, postpaid. Pk., $\$ 1.90$; bu., $\$ 7.00$, not prepaid.

\section{CANADA FIELD PEAS}

FOR FODDER AND GREEN-MANURING

Canada Field Peas make a fattening and milk producing food that will grow on land that will not produce a grain crop and at the same time improve the soil by gathering and storing nitrogen-in this respect it is almost equal to the clovers. Lb., 15c, postpaid. Bu. (60 lbs.), write for prices.

\section{DWARF ESSEX RAPE}

Excellent for grazing sheep, hogs and all kinds of stock. Especially valuable for sheep and hogs with roung, as it is an excellent milk producer. Sow $10 \mathrm{lbs}$. to the acre broadcast; $5 \mathrm{lbs}$. if drilled. Lb., 20c, postpaid. 5 lbs., $75 \mathrm{c}$; 100 lbs., $\$ 12.50$, not prepaid.

\section{GOLDEN MILLET (CHOICE TENNESSEE GROWN)}

To hare the finest millet hay, sow thickly, not less than a bushel to the acre, from the middle of May till the end of July. Thin seeding makes coarse stems and a poorer hay. Sor only Southern grown Millet. Lb., $15 \mathrm{c}$, postpaid. Write for prices on larger quantities.

\section{OATS}

BURT, OR NINETY DAY. The quickest growing, most prolific and free from rust, healthy, clean and makes a rigorous growth of straw, besides a good rield of grain. Bu. (32 lbs.), $\$ 1.25$.

FULGHUM OATS. The Fulghum is probably the most popular of the rust-proof varieties, and one of the earliest. Bu. (32 lbs.), \$1.50.

\section{SEED RYE}

ROSEN RYE. This variety, which was originated by the Michigan State Agricultural Experiment Station, has long broad heads with larger, olumper berries than other rarieties. Is generally regarded as yielding from 5 to 15 bushels more per acre than ordinary rye. Lb., 15c, postpaid. Bu. (56 lbs.), \$2.50, not prepaid.

ABRUZZI. A new importation, and much is claimed for it. The Abruzzi variety has a rery rapid growth and stools enormously on arerage soil. Write for prices.

\section{SORGHUM}

EARLY AMBER. Furnishes a large field of most nutritious forage, good either green or cured, and rielding 2 to 3 cuttings a rear, stoo'ing out thicker each time it is cut. Grows 10 to 12 feet high. Sow at rate of a peck to acre, in drills 3 to 4 feet apart; broadeast, 1 to 11 ; bushels to acre. Lb., $20 \mathrm{c}$; 5 lbs., $75 \mathrm{c}$, postpaid. Bu. (50 lbs.), $\$ 3.00$, not prepaid.

EARLY ORANGE. Iarger than Amber, maturing ten days later. Lb., $25 \mathrm{c}$; 5 lbs., $\$ 1.00$, postpaid. Bu. (50 lbs.), $\$ 3.00$, not prepaid.

\section{SOY, OR SOJA BEANS}

MAMMOTH YELLOW. The largest and most popular variety for forage purposes. A little later in maturity than other kinds, but makes larger jields, both of forage and seed. Especially valuable for this section and farther south. Lb., 20c, postpaid. Pk., $\$ 1.20$; bu. (60 lbs.) $\$ 3.50$, not prepaid.

\section{VETCHES}

SPRING VETCHES or TARES (Vicia sativa) Highly valuable for soiling or for green manuring. Use 2 to 3 bushels per acre broadcast 1 to 2 bushels in drills. Lb., 20c, postpaid. Bu. (60 lbs.), $\$ 5.00$, not prepaid.

WINTER VETCHES or TARES (Vicia villosa). Also called Sand Vetch or Hairs Vetch. Recommended for Fall sowing. Sow 1 bushel of the seed per acre, with 1 bushel of rre. Lb., $25 \mathrm{c}$, postpaid. Bu. (60 lbs.), $\$ 9.00$, not prepaid. 


\section{WILLIAMS' FLOWER SEEDS}

\section{ALL FLOWER SEEDS ARE POSTPAID AND WE GUARANTEE SAFE DELIVERY TO YOUR HOME.}

We give close attention to this department. Our constant aim is to secure the very best strains obtainable, and spare no pains or expense with this object in view.

CULTURE. Light, rich loam is most suitable for flowers. The soil should be finely pulverized for best results. This is of paramount importance if one wishes to grow them successfully. They, in common with all other seeds, should be sown thinly and the soil pressed firmly over them when covered. Water frequently. A good plan is to sow the seed in rows about 4 inches apart, cover the seed about three times its size, then transplant to the permanent garden later. This applies to all the small seeded varieties with the exception of the annual Poppies which should not be transplanted but the plants thinned out. The large seeded varieties as Gourds, Nasturtiums, Ricinus and Sunflower should be planted where they are to bloom. This also applies to annual climbers as they are very difficult to transplant successfully.

ANNUALS are those flowers that attain their full growth, bloom and die the first year. Among these are the Asters, Balsam, Cosmos, Zinnias, Mignonettes, Sweet Peas, Nasturtiums, Morning Glories and other brilliant and fragrant sorts.

BIENNIALS produced from seed generally flower the first and second year and then die, the life of the plant being two seasons. The best examples of this type are Canterbury Bells and Foxgloves. Biennials and perennials should be started in late summer or early fall to get the earliest and best blooms. They may be transplanted into their permanent position as soon as they are large enough, which is usually in November.

PERENNIALS usually do not flower the first year, unless started early in the season. Perennials live and blossom year after year. These sorts constitute the "Hardy Flowers," such as Hollyhocks, Sweet William, etc.

\section{ACHILLEA-MILFOIL OR YARROW}

PTARMICA FL. PL., "THE PEARL." Hardy perennial. Easily grown from seed, flowering the first season if seed is sown early; excellent white double cut flower for vases; 2 feet. Pkt. 20c.

\section{ACONITUM- MONKSHOOD OR HELMET FLOWER}

Handsome, hardy perennial, thriving best in semi-shady situations; effective in hardy borders, shrubberies, etc. : curious hood-shaped flowers in clusters. Height 3 feet.

NAPELLUS. Blue. Pkt., 10c; 3 pkts., 25c.

\section{ACROCLINIUM}

Very pretty annual, producing white and rose colored, daisy-like flowers in August and September. These are the "immortelles," so desirable for Winter bouquets. 1 foot

DOUBLE MIXED. Pkt., 10c; 3 pkts., $25 \mathrm{c}$.

\section{AGERATUM- FLOSS FLOWER}

One of the best bedding plants, being literally a sheet of bloom from early Summer till frost. Can be sown outdoors in April. A sowing in September will give plants to bloom all Winter. BLUE PERFECTION. This is the darkest colored of all large flowering Ageratums. Color deep amethyst-blue; compact growth; fine bedder. Pkt., 10c; $1 / 4$ 0z., 35c.

IMPERIAL DWARF BLUE. Clear blue; 8 inches. Pkt., 10c; 1/4 0z., 35c.

IMPERIAL DWARF WHITE, 8 inches. Pkt, $10 \mathrm{c} ; 1 / 4$ oz., 35c.

\section{AGROSTEMMA}

CORONARIA (Mullein Pink). Silvery foliage and bright crimson flowers ; free-flowering, hardy perennial of easy culture ; fine for cutting; $2 \frac{1}{2}$ to 3 feet. Pkt., 10c; 3 pkts., 25c.

\section{ALYSSUM}

One of the most popular garden flowers, remaining in bloom the entire season; of the easiest culture; suitable for beds and edging in Summer.

LITTLE GEM. Dwarf, compact plants, densely covered with large, white flowers; commences to bloom when quite small; height 4 inches. Pkt., 10c; $1 / 2$ oz., 35c; oz., 60c.

SWEET (Maritimum). The popular old-fashioned sort; the best for broad edges and vases. Pure white; height 9 inches. Pkt., 10c; $1 / 2$ oz., 25c; oz., 40c.

SAXATILE COMPACTUM (Basket of Gold). An ideal hardy perennial plant, flowering in May; showy golden yellow flowers; blooms the first season if shown early indoors; excellent for rockwork. Height 1 foot. Pkt., 10c; 1/4 0z., 35c.

\section{AMARANTHUS}

Decorative foliage plants, easily raised from seed, either by starting them early indoors or sown outdoors in May. Useful in borders of tall plants or for the center of large beds.

CAUDATUS (Love-Lies-Bleeding). Long, drooping crimson racemes; height 3 feet. Pkt., 10c; $1 / 2$ oz., 30c.

TRICOLOR SPLENDENS (Joseph's Coat). Foliage green, variegated crimson and yellow; height 2 feet. Pkt., 10c; $1 / 4$ oz., 25c.

MIXED. All sorts. Pkt., 10c; 1/4 0z., $25 \mathrm{c}$.

\section{ANCHUSA- SEA BUGLOSS}

ITALICA "DROPMORE". Bears an abundance of beautiful flowers of a lovely gentian blue, borne on graceful stems, during the entire season. 4 to 5 feet. Pkt., 15c; $1 / 4$ oz., 40 c.

\section{ANEMONE- WINDFLOWER}

CORONARIA. Hardy perennial, producing large flowers ; excellent for bouquets; mixed colors. $11 / 2$ feet. Pkt., 10c; 3 pkts., 25c.

ST. BRIGID. Flowers large, semi-double and double; in many colors. $1 \frac{1}{2}$ feet. Pkt., 15c; 2 pkts., $25 \mathrm{c}$

\section{ANTHEMIS- HARDY MARGUERITE}

TINCTORIA KELWAYI. A handsome, hardy perennial, bearing all Summer, daisy-like, bright yellow flowers. 3 feet. Pkt., 10c; 3 pkts., 25c. 


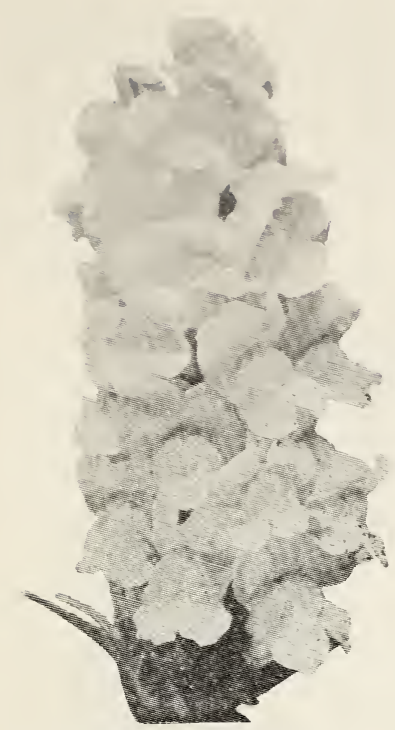

Antirrhinum, Maximum.

\section{ANTIRRHINUM- SNAPDRAGON}

This is considered one of the finest perennials which may be flowered from seed the first year. Seed may be sown in the open ground early in April and be had in bloom in July, but it is best to start the plants indoors in March and transplant the seedlings out-of-doors as soon as weather will permit.

\section{LARGE FLOWERING GIANT VARIETIES}

A splendid strain growing about 30 inches high, with long spikes of large flowers.

BRILLIANT ROSE. Deep rose.

CARDINAL. Bright scarlet.

CRESCIA. Dark velcery red.

GOLDEN KING. Rich yellow.

QUEEN VICTORIA. Pure white.

ROSE QUEEN. Soft pink.

Price, all above varieties: Pkt. $10 \mathrm{c} ; 1 / 1 \mathrm{cz} ., 40 \mathrm{c}$. MIXED. All colors. Pkt., 10c; $1 / 4$ oz., 35 c.

\section{SUPER-GIAN'T VARIETIES}

A new strain of tall, strong growth producing long spikes of extra large flowers. 3 feet. APPLE BLOSSOM. Apple blossom pink.

CATTLEYA. Rosy lilac.

SNOWFLAKE. Pure white.

GOLDEN QUEEN. Canary yellow.

GIANT MIXED. All colors.

Price, all above varieties: Pkt., 20c; 1/8 0z., 50c.

\section{AQUILEGIAS OR COLUIMBINES}

These are among the most beautiful of Spring and early Summer flowers; very effective when grown in the herbaceous border and groups among shrubbery. Graceful spurred flowers on stems 2 feet or more above the foliage. Seed sown early in the Spring will in most cases produce plants that will bloom the same season. 2 to 3 feet.

CALIFORNIA HYBRIDA. Mixed colors, principally yellow and orange shades; long spurs. Pkt., $15 \mathrm{c}$.
CHRYSANTHA (Golden Spurred). Bright golden yellow. Pkt., 10c.

COERULEA (Rocky Mountain Columbine). Large flowers, violet-blue and white. Pkt., 10c.

LONG SPURRED HYBRIDS. Flowers of many rich and varied colors, with long spurs. Pkt., $15 c$.

WHITE. Long spurred white flowers. Pkt., 15c. DOUBLE MIXED. All colors. Pkt., 10c; 1/4 oz. $30 \mathrm{c}$.

SINGLE MIXED. All colors. Pkt., 10c; 1/4 oz., $30 \mathrm{c}$.

\section{ARCTOTIS GRANDIS- THE AFRICAN LILAC DAISY}

Grows in large branching bushes, 2 feet in height and breadth; flowers are white on the upper surface, and pale lilac below. Pkt., 10c; $1 / 4$ oz., 30c.

\section{ASPARAGUS}

Seed start slowly and should be soaked in warm water before sowing. Tender perennials; makes a pillar climber where there is little frost.

PLUMOSUS NANUS. A dwarf variety, very delicate and feathery. Pkt., 20c; 100 seeds, $75 \mathrm{c}$.

SPRENGERI (Emerald Feather). Feathery-leaved variety, with drooping branches. The variety for hanging baskets. Pkt., 10c; 100 seeds, 35c.

\section{AUBRIETIA}

Large Flowered Hybrids. A very compact Spring-flowering perennial in various shades of blue. 6 inches. Pkt., 15c.

\section{BALLOON VINE- LOVE-IN-A-PUFF}

This rapid growing annual climber succeeds best in a light soil and sunny situation. The flowers are white and the seed vessels, which resemble miniature balloons, are very interesting to children. Seed should be sown as soon as ground becomes warm, in an open situation. 8 feet. Pkt., 10c; oz., 30c.

\section{BALSAMS, DOUBLE CAMELLIA-FLOWERED \\ (LADY SLIPPER)}

An old and favorite garden flower, producing its gorgeous masses of beautiful brilliant colored, double flowers in the greatest profusion. 2 feet. FINEST MIXED. A wide range of beautiful

colors. Pkt., 10c; 1/4 0z., $25 \mathrm{c}$.

\section{BEGONIAS}

EVERBLOOMING BEDDING VARIETIES

The following varieties of Begonia semperflorens and $B$. gracilis take rank as bedding plants with geraniums and coleus, doing equally well in full sunlight, and surpassing both in positions partially or wholly in shade. Easily raised from seed, which should be started either indoors or in a hotbed. 1 foot.

GRACILIS LUMINOSA. Brilliant dark scarlet; very effective. Pkt., $25 \mathrm{c}$.

GRACILIS PRIMADONNA. Carmine-rose; brown tinted foliage. Pkt., $25 \mathrm{c}$.

GRACILIS WHITE PEARL. Snowy-white, green foliage. Pkt., 25.c.

SEMPERFLORENS, ERFORDI. Rosy carmine; green foliage. Pkt., $25 \mathrm{c}$.

SEMPERFLORENS, TRIUMPH. Pure, glistening white. Pkt., 25c.

SEMPERFLORENS, VERNON. Bright orangecarmine; red foliage. Pkt., 1 sc.

TUBEROUS-ROOTED SINGLE MIXED. Excellent for indoor culture only. Pkt., 25c.

TUBEROUS-ROOTED DOUBLE MIXED. The double form. Pkt., 25c. 


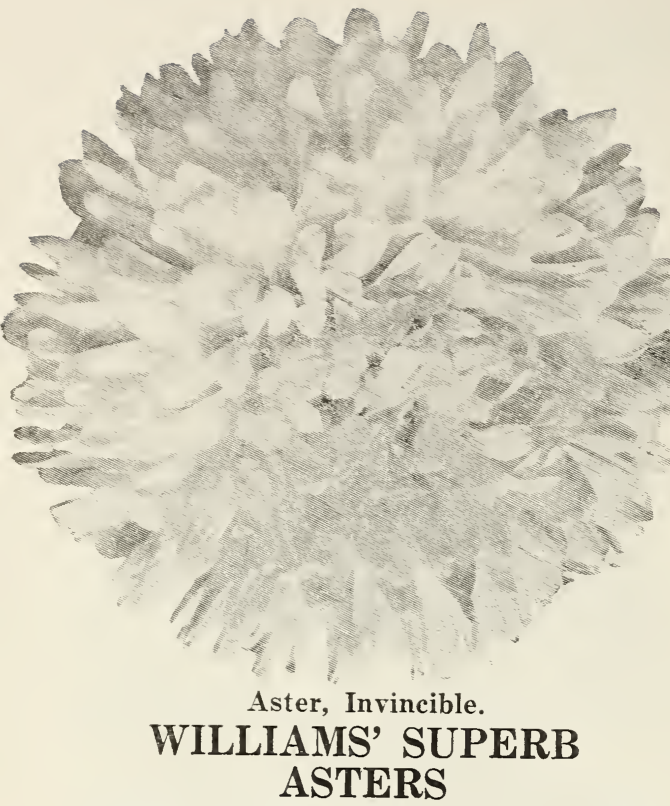

Asters will thrive in any good soil. They should have an open, sunny position, and prefer a good, heavy, loamy soil, enriched with a liberal quantity of bone meal or other good commercial fertilizer.

INVINCIBLE. Healthy, robust plants of branching growth, producing on 2-foot stems, massive, well formed flowers, which are always perfectly double.

Crimson. Rich bright red. Pkt., 10c; 1/4 oz., 60c.

Deep Blue. Bright indigo-blue. Pkt., 10c; 1/4 oz., 60c.

Lavender. Charming silvery lavender. Pkt., $10 \mathrm{c} ; 1 / 4$ oz., $60 \mathrm{c}$.

Rose-Pink. Bright rose. Pkt., 10c; 1/4 oz., 60c.

Pure White. Purest snow-white. Pkt., 10c; $1 / 4$ oz., $60 \mathrm{c}$.

Mixed Colors. Pkt., 10c; 1/4 oz., 50c.

Collection of Invincible Asters. One pkt. each of the above 5 varieties. $40 \mathrm{c}$ postpaid.

OSTRICH FEATHER. The flowers of this class resemble the Japanese chrysanthemum with their long, curved, fringelike petals, giving a feathery appearance; of immense size. $11 / 2$ feet. Finest Mixed. Pkt., 10c; 1/4 oz., 60c.

SEMPLE'S LATE-FLOWERING. Superior lateflowering branching Asters. The flowers are large, very double and borne on long stems. They begin blooming about the first of September. 18 inches to 2 feet high.

Crimson. Pkt., 10c; $1 / 4$ oz., 50c.

Lavender. Pkt., 10c; 1/4 oz., 50c.

Purple. Pkt., 10c.; 1/4 oz., 50c.

Choice Mixed. Pkt., 10c; $1 / 4$ oz., $40 \mathrm{c}$

Rose-Pink. Pkt., 10c; 1/4 oz., 50c.

Shell-Pink. Pkt., 10c; 1/4 oz., 50c.

White. Pkt., 10c; 1/4 oz., 50c.

Collection. One pkt. each of the above 6 colors. $50 \mathrm{c}$.

CREGO'S GIANT. We consider this the finest and largest of all Crego Asters, bearing immense, fluffy flowers five inches and over in diameter.

White. Pure white. Pkt., 10c; 1/4 oz., 75c.

Pink. Delicate shell-pink. Pkt., 10c; 1/4 0z., 75c. Azure-Blue. Bright blue. Pkt., 10c; 1/4 oz., 75c. Rose. Rich deep rose. Pkt., 10c; 1/4 oz., 75c.

Lavender. Deep lavender. Pkt., $10 \mathrm{c} ; 1 / 4 \mathbf{0 z}_{.}, 75 \mathrm{c}$.

Crego's Mixed. All colors. Pkt., 10c; 1/4 oz., 60c.

Collection. One pkt. each of the above 5 colors, $40 \mathrm{c}$, postpaid.
EARLY WONDER ASTERS. This is the best extra early Aster, flowering in early July from seeds sown in the open ground at the end of April, and if sown in March can be had in bloom before the close of June. The flowers are of good size, quite double, and are borne on good long, stiff stems. Pkt., 15c; 1/4 oz., $\$ 1.00$.

PERENNIAL ASTERS (Michaelmas Daisy).

Choice Mixed. One of the showiest of our late flowering, perennial plants; starlike, single flowers. 2 feet. Pkt., 15c; 2 pkts., 25c.

\section{BELLIS-ENGLISH DAISY}

Very effective for bedding alone, or interspersed with pansies or forget-me-nots, etc. 6 inches.

GIANT CRIMSON. Fine color. Pkt., 15c; 1/8 oz., $75 \mathrm{c}$.

GIANT ROSE. Magnificent strain. Pkt., 15c; 1/8 oz., 75c.

GIANT WHITE. Perfect double blooms. Pkt., $15 \mathrm{c} ; 1 / \mathrm{s}$ oz., $75 \mathrm{c}$.

DOUBLE MIXED. Pkt., 10c; 1/8 oz., 60c.

\section{CALCEOLARIA}

The strains offered herewith are grown by a famous English seed growing specialist and are the finest in existence. The Giant Strain is intended for conservatory growing; the Rugosa for outside bedding.

GIANT STRAIN. $1 \frac{1}{4}$ feet. Pkt., 40c.

RUGOSA. 1 foot. Pkt., 35c.

\section{CALLIOPSIS}

An old-fashioned flower and a general favorite. It grows about 3 feet high and is fine for cutting and some sorts for bedding. Hardy annual. Blossoms single and about 2 to 4 inches in diameter.

MIXED. A gorgeous mixture of golden yellow, brown, maroon and other shades. Pkt., 10c $1 / 2$ oz., 25c.

\section{CANARY BIRD VINE}

TROPAEOLUM CANARIENSE. A beautiful rapid growing annual climber. the charming little canary-yellow blossoms bearing a fancied resemblance to a bird with its wings half expanded. Pkt., 10c; 1/2 oz., 25c.

\section{CANDYTUFT-IBERIS UMBELLATA}

The annual Candytufts are universally known and cultivated, and considered indispensable for cutting. 1 foot.

CRIMSON. Rich deep shade. Pkt., 10c; 1/2 oz., $30 \mathrm{c}$.

FLESH PINK. Delicate Pink. Pkt., 10c; $1 / 2$ oz., $30 \mathrm{c}$.

LAVENDER. Delicate shade of rosy lavender. Pkt., 10c; 1/2 oz., 30c.

ROSE CARDINAL. Brilliant deep rosy red; one of the most effective for bedding. Pkt., 10c; $1 / 2$ oz., 30c.

MIXED. A splendid mixture containing all the colors. Pkt., 10c; 1/2 oz., 25c.

GIANT HYACINTH-FLOWERED. A wonderfully improved strain of the popular Empress Candytuft. Pure white flowers. Pkt., 10c; 1/2 0z., 40c. GIBRALTARICA HYBRIDA (Hardy Candytuft). White shading to lilac. Pkt., 10c; $1 / 4$ oz., 50c.

\section{CARDINAL CLIMBER (IPOMOEA QUAMOCLIT HYBRIDA)}

A beautiful annual climber; a rapid grower and free bloomer; the vines branch freely, covering a large space very quickly and growing to a height of 20 to 30 feet. Bears a profusion of fiery, cardinal-red flowers, which are about $11 / 2$ inches in diameter. Pkt., 15c; 1/4 0z., 60c. 


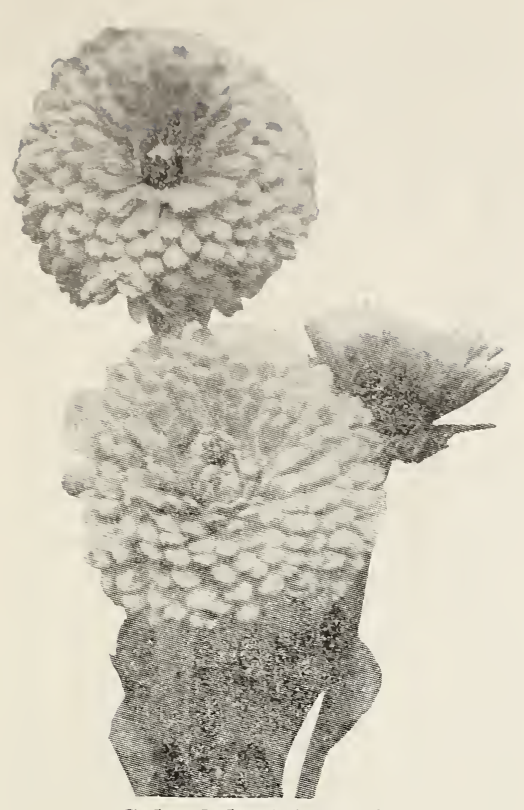

Calendula, The Ball.

\section{CALENDULA-POT MARIGOLD}

Free-flowering, showy annuals of easy culture, producing a fine effect in beds or mixed borders; continues in bloom from early Summer until killed by frost. Valuable for pot culture, blooming freely in Winter and early Spring. 1 foot.

ORANGE KING. Deepest orange. Pkt., 10c; 1/2 oz., 25 c.

BALL'S STRAIN. Bright, glowing orange; large and double. Pkt., 15c; $1 / 4$ oz., 75c.

LEMON KING. Lemon-yellow. Pkt., 10c; 1/2 oz., 25 c.

MIXED. Pkt., 10c; 1/2 0z., 20c.

\section{CANTERBURY BELLS}

CAMPANULA MEDIUM. Showy, hardy biennial, growing about 3 feet high; of pyramidal form and covered with large, bell-shaped flowers. Sow from June 1st till September 1st.

Single Blue. Pkt., $10 \mathrm{c}$; $1 / 4$ oz., 30c.

Single Pink. Pkt., 10c; $1 / 4$ oz., 30c.

Single White. Pkt., 10c; $1 / 4$ oz., $30 \mathrm{c}$.

Single Mixed. Pkt., 10c; 1/4 oz., 25c.

Double Blue. Pkt., 10c; 1/4 0z., 75c.

Double Pink. Pkt., 10c; 1/4 oz., 75c.

Double White. Pkt., 10c; $1 / 4$ oz., 75c.

Double Mixed. Pkt., 10c; $1 / 4$ oz, 60 c.

CAMPANULA MEDIUM CALYCANTHEMA (Cup and Saucer Canterbury Bells). These produce beautiful, large, single flowers, resembling a cup and saucer.

Blue. Pkt., 10c; $1 / 8$ oz., 50c.

Pink. Pkt., 10c; $1 / 8$ oz, 50c.

White. Pkt., 10c; 1/8 oz., 50c.

Mixed. Pkt., 10c; $1 / 8$ oz., 40c.

\section{CHRYSANTHEMUMS}

The plants average 2 feet in height, and bear their daisy-like flowers in great profusion on strong stems.

SINGLE ANNUAL VARIETIES MIXED. Choice, Pkt., 10c; 3 pkts., 25c.

DOUBLE ANNUAL VARIETIES MIXED. Mixture of double varieties. Pkt., 10c;3 pkts., 25 c.

\section{CARNATION}

These are general favorites for their richness of color and delightful fragrance; they are desirable for greenhouse culture in Winter as well as for the garden in Summer.

CHABAUD'S EVERBLOOMING. This large flowering strain blooms five months after being sown and continues to bloom indefinitely. 18 inches.

Pink. Pkt., 20c. Scarlet. Pkt., 20c.

White. Pkt., 20c. Yellow. Pkt., 20c.

Mixed. Pkt., 15c; 1/4 oz., 60c.

MARGUERITE. These are the most satisfactory of the annual Pinks, and they will bloom in four months after sowing. The flowers are large and fragrant.

Choice Mixed. Pkt., 10c; 1/4 0z., 50c.

\section{CELOSIA CRISTATA}

\section{(CRESTED COCKSCOMB)}

Very desirable annuals of easy culture, producing large, brilliant, comblike heads.

CHOICE MIXED. Dwarf varieties. Pkt., 10c;

$1 / 4$ oz., $60 \mathrm{c}$.

\section{CELOSIA PLUMOSA} (FEATHERED COCKSCOMB)

A splendid decorative plant for the garden. The feathery plumes are produced on long stems and are excellent for cutting. Can also be cut and dried for Winter bouquets.

PRIDE OF CASTLE GOULD. Immense flower heads that closely resemble ostrich plumes. Colors are blood-red, carmine, yellow, orange, golden, orange-scarlet, etc. Pkt., 15c; 2 pkts. $25 \mathrm{c}$

CHOICEST MIXED. All colors. Pkt., 10c; 1/4 oz., $60 \mathrm{c}$.

CHILDSI (Chinese Woolflower). Pkt., 10c; 3 pkts., 25 c.

\section{CENTAUREA}

CANDIDISSIMA. Extensively used for ribbon beds, edgings, vases, etc. The foliage is silvery gray. 1 foot. Pkt., 10c; 3 pkts., 25c.

CYANUS (Cornflower or Bachelor's Button). Also known as Blue Bottle, Ragged Sailor, Bluet, etc. An old favorite garden annual, flowering freely in almost any situation; excellent for cutting; 2 feet.

Double Blue. Large flowering. Pkt., 10c; 1/4 oz., 25c.

Double Rose. Pkt., 10c: 1/4 oz, 25c.

Double Mixed. Pkt., 10c; 1/2 oz., 20c.

IMPERIALIS (Sweet Sultan). The finest of all Sweet Sultans for cut flower purposes; gigantic, beautiful, sweet scented flowers borne on long stems. Height 2 to 3 feet. Pkt., 10c.

\section{CINERARIA}

Most ornamental plants for conservatory or house decoration.

GRANDIFLORA, PRIZE DWARF. Mixed colors; plants of dwarf habit. 1 foot. Pkt., 40c.

GRANDIFLORA, PRIZE MEDIUM TALL. Mixed colors; desirable as a decorative plant. $1 \frac{1}{2}$ feet. Pkt., 50c.

\section{CLARKIA}

This pretty and easily grown annual has been much improved in recent years. It does well either in sun or shade, growing 2 to $2 \frac{1}{2}$ feet high, with leafy racenes of double flowers.

ELEGANS DOUBLE MIXED. Pkt., 10c; 1/4 0z. $40 \mathrm{c}$.

\section{COBAEA SCANDENS}

A half-hardy climbing perennial, with large lesves and large, bell-shaped flowers. Blossom is green until nearly grown, when it turns bright purplish blue. Grows about 30 feet long, and is very desirable for covering a large lattice. A native of Mexico. Pkt., 10c; 3 pkts., 25c. 


\section{CLEMATIS}

Perennial climber; fine for arbors, verandas, etc. PANICULATA (Japanese Virgin's Bower). The beautiful autumn-flowering variety, admired for its fragrant, white, star-shaped flowers. Pkt., $10 \mathrm{c} ; 3$ pkts., 25c.

\section{COLEUS}

LARGE-LEAVED HYBRIDS. Popular bedding plants with beautifully colored foliage; easily grown from seed. Pkt., 25c.

\section{CONVOLVULUS OR MORNING GLORY \\ MAJOR VARIETIES.}

These beautiful annual climbers are of easy culture and produce freely all Summer long, large, funnel-formed flowers of lovely colors and combinations of coloring. Seed may be sown in the open ground. Height 15 to 20 feet.

JAPANESE IMPERIAL. Flowers of immense size and of a great variety of colors. Pkt., 10c; $1 / 2$ oz., 20 c.

MIXED. The old-fashioned variety. Pkt., 10c; oz., 25c.

\section{COREOPSIS}

LANCEOLATA GRANDIFLORA. This is one of the finest of hardy plants, with large, showy, bright yellow flowers, produced in the greatest abundance from June till frost. Pkt., 10c; 1/4 oz., 30c.

\section{COSMOS}

Beautiful Autumn flowers; fine for cutting, and extremely showy in the garden. Our Giant Lady Lenox grows 7 feet high, and begins blooming in September.

GIANT LATE-FLOWERING or LADY LENOX. Huge flowers, often measuring 5 inches across, on long stems. It is best to start seed of the late-flowering Cosmos in the frame in March and April.

Pink. Pkt., 10c; 1/4 oz., 25c.

White. Pkt., 10c; $1 / 4$ oz., 25 .

Crimson. Pkt., 10c; $1 / 4$ oz., 25 c.

Mixed. Pkt., 10c; 1/4 oz., 20c.

GIANT EARLY-FLOWERING. From seeds sown in May, plants begin to bloom in July and continue until frost. Height 4 feet.

Mixed. Pkt., 10c; $1 / 4$ oz., 25c.

CRESTED or ANEMONE-FLOWERED. The flowers are double crested, having double centers, with a row of guard petals around the base, which make them very effective. The colors are pink, crimson and white, offered in mixture. Pkt., 15c; 2 pkts., 25c.

\section{COWSLIP-PRIMULA VERIS}

MIXED. A beautiful hardy Spring-flowering perennial; flowers of different colors, such as yellow, brown-edged yellow, etc. Very fragrant. 6 inches. Pkt., 15c; 2 pkts., 25c.

\section{CYCLAMEN}

Charming greenhouse plants with beautiful foliage and rich colored flowers of enormous size, borne well above the foliage on long, stiff stems.

PERSICUM. A very fine strain, not so large but easier to grow than the Giants; mixed colors. Pkt., 25c.

BUTTERFLY. In this type the edges of the flowers are beautifully fringed or waved; for house or conservatory decoration they are of surpassing beauty. Mixed color's. Pkt., 50c.

CYNOGLOSSUM AMABILE

CHINESE FOR-GET-ME-NOT. This annual was recently introduced from China. The flowers are a beautiful shade of deep blue on long graceful branches. 2 feet. Pkt., 15c; 1/4 oz., 40c.
CYPRESS VINE-STAR FLOWER

(IPOMOEA QUAMOCLIT)

Excellent trailing upon a light trellis. Starshaped blossoms. Hardy annual climber. 10 to 15 feet.

MIXED COLORS. Pkt., 10c; 1/2 oz., 35c.

\section{DAHLIA}

Half-hardy perennial. The seed we offer has been saved from a superb collection of the finest named varieties.

DOUBLE - FLOWERING MIXED. Pkt., 15c; 2 pkts., 25c.

\section{DELPHINIUM-HARDY PERENNIAL LARKSPUR}

These are taller than the annual sorts and their brilliant flower spikes arrest your attention even at a distance. The foliage is attractive and the plants strong and neat in habit. We advise sowing in a box in prepared soil and under a glass.

BELLADONNA. New. Beautiful turquoise-blue, and a continuous bloomer; spikes of good size. Pkt., 25c: 5 pkts., $\$ 1.00$.

FORMOSUM. Bright blue flowers with white center. Pkt., 25c; 1/8 oz., 75c.

GOLD MEDAL HYBRIDS. This is one of our most important specialties, and is unquestionably the finest strain of mixed hybrids ever offered. The plants are of strong, vigorous habit, with large flowers on spikes two feet and over long, the majority running in the lighter shades of blue. Pkt., 15c; 2 pkts., 25c.

CHINESE GRANDIFLORUM. A dwarf strain with sprays of bright blue flowers. 2 feet. Pkt., 10c; 3 pkts., 25c.

\section{DIANTHUS-PINKS}

Dianthus are better known as Old Fashioned Pinks. They grow well in almost any kind of soil and location. However a fairly heavy and fertile soil will give the healthiest plant, largest blooms and richest colors.

\section{DOUBLE ANNUAL VARIETIES}

LUCIFER. Brilliant orange-scarlet, flowers measuring about 2 inches across; very dazzling and popular variety; nicely fringed. Pkt., 15c; 2 pkts., 25c.

SALMON KING. Brilliant salmon-rose. Pkt., 15c; 2 pkts., 25c.

SNOWBALL. Large, double white; excellent for border or cutting. Pkt., 15c; 2 pkts., 25c.

HEDDEWIGI FL. PL. (Double Japan Pink). Double mixed, colors varying from richest crimson to most delicate rose. Pkt., 10c; 3 pkts. $25 \mathrm{c}$.

CHINENSIS FL. PL, (China or Indian Pink) Flowers are borne in clusters, very double and in a large range of bright colors. Pkt., 10c; 3 pkts., 25c.

\section{SINGLE ANNUAL VARIETIES}

Among these single sorts are many beautiful varieties, and the flowers often measure 2 to 3 inches in diarpeter. They are very effective for borders or beds.

CRIMSON BELL. Rich crimson. Height 1 foot. Pkt., 10c; 3 pkts., 25c.

QUEEN OF HOLLAND. Beautiful white. Pkt., 10 c; 3 pkts., $25 \mathrm{c}$.

SALMON QUEEN. Beautiful fringed flowers of brilliant salmon color changing to old-rose when fading. Pkt., 10c; 3 pkts., 25c.

SINGLE MIXED. All large flowering varieties unrivalled for their brilliancy and rich variety of color. They bloom in perfect succession during the whole summer and autumn in such numbers as fairly to crowd each other for room. Pkt., 10c; $1 / 4$ oz., 25c. 
HARDY GARDEN PINKS

These form low, bushy, tufted plants, above which are produced, on long stems, the beautiful fringed and fragrant flowers so valued in "oldfashioned" gardens. For permanent beds and borders these Pinks are unrivalled.

PLUMARIS. Single Mixed. (Scotch Pink, Grass Pinks or Pheasant-eye Pinks). Large, fragrant flowers of beautiful colors and finely fringed. Pkt., 10c; 3 pkts., 25 c.

PLUMARIS. Double Mixed. (Double Hardy Garden Pinks). Fringed, fragrant flowers in many shades, pink, red and white with some spotted and variegated varieties. Pkt., 15c; 2 pkts., 25c.

\section{DIDISCUS-BLUE LACE FLOWER}

COERULEA. Blooms profusely from July till November. The exquisite pale lavender blossoms are excellent for cutting; plants grow about 18 inches high, and have as many as fifty flowers open at one time. Pkt., 15c; 2 pkts., 25c.

\section{DIGITALIS-FOXGLOVE}

Handsome ornamental hardy plants of stately growth. Produce long spikes of beautiful, tubular flowers. 4 feet.

GLOXINIAEFLORA ROSE. Pkt., 10c; 3 pkts., $25 \mathrm{e}$.

GLOXINIAEFLORA PURPLE. Pkt., 10c; 3 pkts.,

GLOXINIAEFLORA WHITE. Pkt., 10c; 3 pkts., 25 c.

GLOXINIAEFLORA MIXED. Pkt., 10c; $1 / 4$ oz.,

THE SHIRLEY. (New). Magnificent strain, enormous flowers; pure white to deepest rose. Pkt., 15c; 2 pkts., 25c.

\section{DIMORPHOTHECA (AFRICAN GOLDEN DAISY)}

AURANTIACA. The flowers, which are $21 / 2$ inches and over across, are a unique, rich, glossy orange-gold, with dark disc and halo. Pkt., 10c; 3 pkts., 25c.

\section{DOLICHOS-HYACINTH BEAN}

A rapid growing annual climber. Fine for covering arbors, trellises, etc. Height 10 feet.

DAYLIGHT. This grand Hyacinth Bean comes from Japan. The heart-shaped foliage is bright green and not affected by insect pests. Pkt., $10 \mathrm{c}$; oz., 30c.

DARKNESS. Rich purple-violet. Pkt., 10c; oz. $30 \mathrm{c}$

LABLAB MIXED. Pkt., 10c; oz., 25c.

\section{ESCHSCHOLTZIA}

\section{(CALIFORNIA POPPY)}

A most showy and free-flowering annual. It flowers early, and where the weather remains cool keeps on blooming until October. The plants are particularly well adapted for beds or borders. They are dwarf and spreading, growing about a foot tall, with gaily colored flowers of a satiny finish.

GOLDEN WEST. Bright yellow with a large blotch of deep orange at the base of the petals. This is a most beautiful variety with large flowers. Pkt., 10c; 1/4 oz., 25c.

MANDARIN. The inside petals of this variety are orange, the outside scarlet. Pkt., 10c; 1/4 oz., $35 \mathrm{c}$.

ROSE CARDINAL. Soft creamy white backed with satiny rosy pink. Truly a charming variety. Pkt., 10c; 1/4 oz., 35c.

CHOICE MIXED. Pkt., 10c; 1/4 oz., 30c.

\section{EUPHORBIA}

Plants with ornamental foliage; very showy and easily raised from seed. Height 2 feet.

VARIEGATA (Snow-on-the-Mountain). Foliage veined and margined with white. Pkt., 10c; 3 pkts., 25 c.
GAILLARDIA-BLANKET FLOWER

ANNUAL VARIETIES

A splendid garden flower and excellent for cutting. The large, highly colored, daisy-like flowers appear uninterruptedly the entire season on stout, erect stems often 15 to 18 inches in length.

PICTA LORENZIANA. Double mixed. Pkt., 10c; $1 / 4$ oz., 30c.

PERENNIAL VARIETIES

One of the most brilliant of hardy perennials blooming the first year from seed if sown early. 2 feet.

GRANDIFLORA COMPACTA. A compact variety choice mixed colors; 12 to 15 inches. Pkt., $10 \mathrm{c}$ $1 / 4$ oz., $40 \mathrm{c}$

\section{GENTIANA-BLUE GENTIAN}

ACAULIS. A dwarf, hardy perennial; deep blue flowers; suited to moist, shady situations. 6 inches. Pkt., 15c; 2 pkts., 25c.

\section{GERANIUM}

ZONALE MIXED. A superb strain of the largest and finest varieties. 1 to 2 feet. Pkt., 15c; 2 pkts., 25 c.

\section{GEUM}

MRS. BRADSHAW. A beautiful hardy perennial with large glowing red double flowers. Blooms all the summer and is splendid for cutting. 2 feet. Pkt., 15c; 2 pkts., 25 c.

\section{GLOBE AMARANTH- GOMPHRENA}

Popularly known as "Bachelor's Button," \& first rate bedding plant; the flowers resemble clover heads and can be dried and used in Winter bouquets.

MIXED. 2 feet. Pkt., 10c; 1/4 oz., 25c.

\section{GLOXINIA}

HYBRIDA GRANDIFLORA. An extra fine strain, embracing all the choicest self colored, tigered, and spotted flowers. Pkt., 25c.

\section{GOURDS}

A vigorous class of plants, with curiously formed and often strangely colored fruits. The foliage is abundant and often curious.

MIXED. All sorts. Pkt., 10c; 0z., 30c.

\section{GYPSOPHILA-BABY'S BREATH}

Pretty, free-flowering plants of easy culture; excellent for cutting to mix with other flowers. 2 feet.

ELEGANS ALBA GRANDIFLORA (True Paris Market Strain). A splendid annual variety; sprays of pure white flowers. Pkt., 10c; 0z., $30 \mathrm{c}$.

PANICULATA. Hardy perennial; flowers in graceful sprays of white. Pkt., 10c; 3 pkts., 25c. PANICULATA FL. PL. Perennial, with a profusion of double white flowers. Pkt., 20c.

\section{HELICHRYSUM- STRAWFLOWER}

Is the best and most satisfactory of the everlasting flowers and makes a very handsome dried bouquet. 3 to 4 feet. Hardy annual.

MONSTROSUM MIXED. Pkt., 10c; 1/4 oz., 30c.

\section{HELIOTROPE}

A well known and highly prized plant on account of the delightful fragrance of the flowers: seed started indoors in the Spring will make fine plants for Summer blooming. 1 foot.

CHOICE MIXED. Of many varieties. Pkt., 10c; 3 pkts. 25c. 


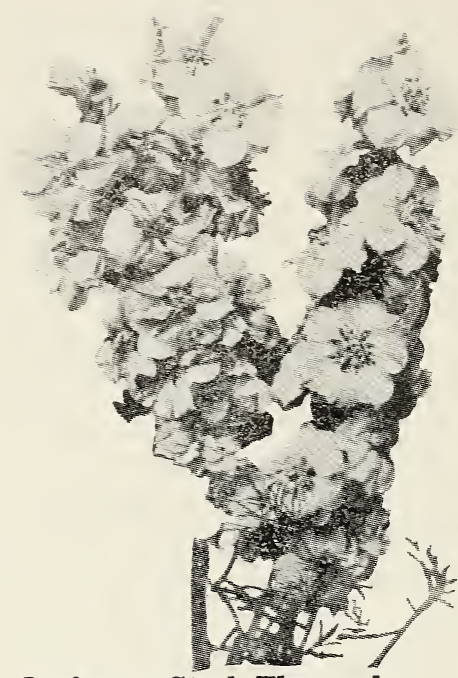

Larkspur, Stock Flowered.

\section{HIBISCUS \\ MARSHMALLOW}

Showy ornamental perennial plants for mixed beds or shrubbery borders.

NEW GIANT (Mallow Marvel). A greatly improved form; gigantic single flowers; many shades of red, pink, purple and white in mixture. Pkt., 15c; 2 pkts., 25 c.

\section{HOLLYHOCK}

One of the most majestic of hardy plants, and a clump or line in any garden gives an effect not attainable with any other plant. 5 to 7 feet.

CHATER'S DOUBLE CRIMSON. Pkt., 10c; 1/4 oz., $75 \mathrm{c}$.

DOUBLE NEWPORT PINK. Pure pink. Pkt., $10 \mathrm{c} ; 1 / 4$ oz., $75 \mathrm{c}$.

CHATER'S DOUBLE ROSE. Pkt., 10c; 1/4 oz., $75 \mathrm{c}$.

CHATER'S DOUBLE SCARLET. Pkt., 10c; $1 / 4$ oz., $75 \mathrm{c}$.

CHATER'S DOUBLE WHITE. Pkt., 10c; $1 / 4$ oz., $75 \mathrm{c}$.

CHATER'S DOUBLE YELLOW. Pkt., 10c; 1/4

CHATER'S DOUBLE MIXED. Pkt., 10c; $1 / 4$ oz., $50 \mathrm{c}$.

SINGLE MIXED. Pkt., 10c; 1/4 oz., 40c.

ANNUAL EVERBLOOMING HOLLYHOCKS. A strain which flowers the first year from seed. Pkt., 15c; 2 pkts., $25 \mathrm{c}$.

\section{HUMULUS-JAPAN HOP}

A rapid Summer climber which in three to four weeks' time attains a height of 20 to 30 feet.

JAPONICUS. Pkt., 10c; 1/4 oz., 25c.

\section{HUNNEMANNIA}

\section{(GIANT YELLOW TULIP POPPY)}

FUMARIAEFOLIA. Sown outdoors in May it produces large quantities of giant yellow tuliplike flowers. Height 2 feet. Pkt., 10c; 1/4 oz., $40 \mathrm{c}$.

\section{IPOMOEA}

NOCTIFLORA (Moonflower). At night and during dull days the plants are covered with an abundance of large, pure white, fragrant flowers. Pkt., 10c; $1 / 2$ oz., 35c.

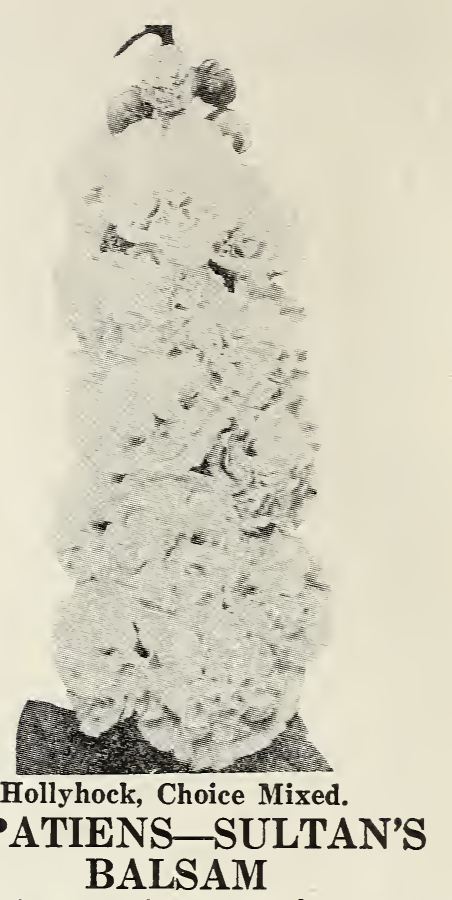

A charming plant for house and conservatory decorations.

SULTANI HYBRIDS. Colors range from pale pink to dark crimson. Pkt., 25c.

\section{IRIS-FLOWERING FLAX}

KAEMPFERI (Japanese Iris). Hardy perennial; very showy; blooms the second year from seed. Pkt., 10c; 3 pkts., 25c.

\section{KENILWORTH IVY}

(LINARIA CYMBALARIA)

A charming, neat trailing plant, for baskets and vases. Pkt., 10c; 3 pkts., 25 c.

\section{KOCHIA TRICHOPHYLLA}

\section{(SUMMER CYPRESS)}

Annual plant, forming dense oval bushes, 2 to $21 / 2$ feet high, of small, feathery, light green foliage. As Summer advances this changes to a carmine hue and finally to a fiery red. Also called "Burning Bush." Pkt., 10c; 1/2 0z., 25 c.

\section{KUDZU VINE}

\section{(PUERARIA THUNBERGIANA)}

Called also Jack-and-the-Bean-Stalk. Hardy perennial. The first year it will do 10 feet and the next up to 50 feet. Fine for a permanent vine. Pkt., 10c; 1/4 oz., 25 c.

\section{LARKSPUR}

\section{(ANNUAL)}

Of easy culture; seed sown early in Spring will produce blooming plants by July; fernlike foliage and slender spikes with double rosette flowers.

TALL DOUBLE STOCK-FLOWERED

Plants branch freely, bearing long spikes of beautiful double flowers. Height $2 \frac{1}{2}$ feet.

CARMINE. Pkt., 10c; $1 / 4$ oz., $30 \mathrm{c}$.

DARK BLUE. Pkt., 10c; $1 / 4$ oz., 30c.

LILAC. Pkt., 10c; $1 / 4$ oz., 30c.

ROSE PINK. Pkt., 10c; 1/4 0z., 30c.

SHELL PINK. Pkt., 10c; $1 / 4$ oz., 30c.

SKY BLUE. Pkt., 10c; $1 / 4$ oz., 30c.

WHITE. Pkt., 10c; $1 / 4$ oz, 30c.

COLLECTION. One pkt. each of above 7 colors, $60 c$.

MIXED. All colors. Pkt., 10c; $1 / 4$ oz., 25 c. 


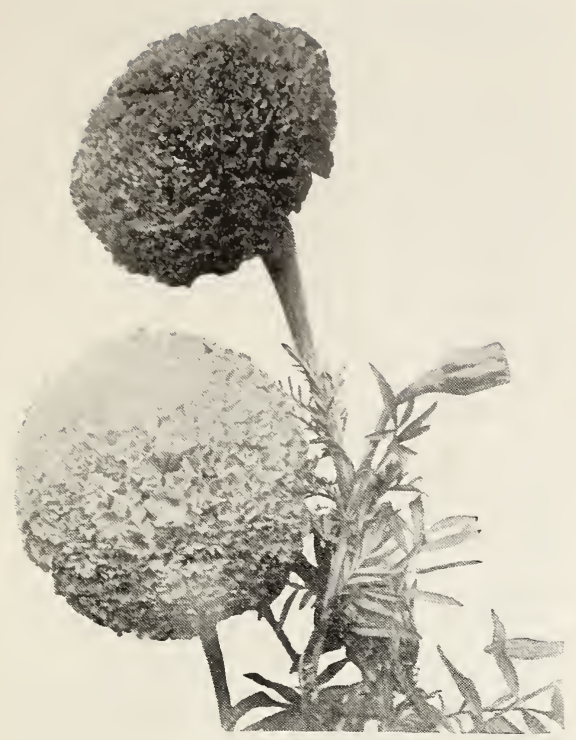

African Marigolds.

\section{LANTANA}

One of the most desirable half-hardy greenhouse or bedding plants. Pkt., 10c; $1 / 4$ oz., 30c.

\section{LATHYRUS}

(EVERLASTING OR HARDY SWEET PEA)

Hardy climbers, growing 6 to 8 feet high when trained on a trellis. The flowers are borne in large clusters. They are peculiarly adapted to rough places, to scramble over rocks and bushes. WHITE. Pkt., 15c; $1 / 2$ oz., 75c.

DELICATA. Rosy flesh color. Pkt., 15c; $1 / 2$ oz., $75 c$.

RED. Pkt., 15c; 1/2 oz., 75c.

MIXED COLORS. Pkt., 10c; 1/2 oz., 60c.

\section{LINUM-SCARLET FLAX}

GRANDIFLORUM RUBRUM. Ideal for bedding

dwarf and compact. 1 foot. Pkt., 10c; $1 / 4$ oz., 25c.

PERENNE. Bright blue flowers; perennial. 2 feet. Pkt., 10c; 1/4 oz., 40c.

\section{LOBELIA}

These bloom very quickly from seed and flower all through the season. For beds. edgings, baskets and pots.

CRYSTAL PALACE COMPACTA. Rich deep

blue; dark foliage. The finest variety for bedding. Pkt., 10c; 3 pkts., 25c.

EMPEROR WILLIAM. A very compact variety with sky-blue flowers. Pkt., 10c; 3 pkts., $25 \mathrm{c}$.

\section{LUPINUS-LUPINE}

This very interesting class of plants is of easy culture and produces beautiful leaves and peashaped flowers. The following annual varieties may be sown out in the open in April.

ANNUAL VARIETIES. Mixed. 2 feet. Pkt.,

10c; 3 pkts., 25 c.

PERENNIAL VARIETIES. Mixed. 3 feet. Pkt.,

10c; 3 pkts., 25 c.

\section{LYCHNIS}

Handsome hardy perennial plants of easy culture, for massing in beds or borders.

CHALCEDONICA. Fine scarlet flowers, 2 feet. Pkt., 10c; 3 pkts., 25c.

\section{MARIGOLDS}

\section{DOUBLE AFRICAN MARIGOLDS}

Splendid for beds or borders; the tall varieties grow about 3 feet high, the dwarf sorts 18 to 24 inches.

ORANGE PRINCE. Large, perfect double quilled flowers of a rich golden orange color. Pkt., 10c; $1 / 4$ oz., 40c.

LEMON QUEEN. A counterpart of Orange Prince except in color, which is a soft lemon-yellow. Pkt., 10c; $1 / 4$ oz., 40c.

DOUBLE MIXED. African varieties containing all of the colors. 2 to 3 feet. Pkt., 10c; 1/4 oz., 30c.

DWARF DOUBLE FRENCH MARIGOLDS

Few annuals are as effective as the French Marigolds or flower for so long a period; they all form dense bushes not over 12 inches high, and are unequalled for borders or beds.

FRENCH MIXED. A splendid mixture saved from the double flowers; all colors. Pkt., 10c; $1 / 4$ oz., 30c.

\section{MARVEL OF PERU- FOUR O'CLOCK}

CHOICE MIXED. Bushy plants of easy culture, producing hundreds of flowers during the entire Summer. 2 feet. Pkt., 10c; oz., 35c.

\section{MATRICARIA- FEVERFEW}

GRANDIFLORA FL, PL. EXIMIA. Half-hardy perennial. Double, pure white flowers are borne on slender stems 15 inches high. 2 feet. Pkt., 10c; 3 pkts., 25 c.

\section{MESEMBRYANTHEMUM}

CRYSTALLINUM (Ice Plant). Dwarf, trailing annual plants; flowers white. Pkt., 10c; 3 pkts., 25c.

\section{MIGNONETTE}

Valuable for cutting on account of its fragrance; sow in succession during the whole Summer: can also be grown in pots for Winter and early Spring flowering.

MACHET. Large reddish tinted, sweet scented flowers. Pkt., 10c; 1/4 0z., 25c.

SWEET SCENTED. The popular garden sort. Pkt., 10c; 1/2 oz., 25c.

\section{GIANT NASTURTIUMS}

Few garden annuals respond with as little care as the Nasturtium. For ease of culture, duration of bloom, brilliancy of coloring and general excellence, they are unexcelled. All they need is a moderately good soil, in a well-drained sunny position.

TOM THUMB DWARF OR BEDDING

BEAUTY. Light scarlet, mottled yellow. Pkt., 10c; oz., 25c.

GOLDEN KING. Rich golden yellow, dark leaved. Pkt., 10c; oz., 25c.

KING OF TOM THUMBS. Dark scarlet; dark foliage. Pkt., 10c; oz., 25c.

PEARL. Pure white. Pkt., 10c; oz., 25̃c.

VESUVIUS. Dark foliage and rich salmon rose flowers. Pkt., 10c; oz., 25c.

GIANT - FLOWERING TOM THUMB. Mixed colors. Pkt., 10c; oz., 15c; 1/4 lb., 50c; lb., \$1.50. TALL OR CLIMBING VARIETIES

Elegant and luxuriant climbers for verandas, trellises, etc. May be used to cover unsightly railings and to trail over rough ground with fine effect. 6 to 10 feet.

GIANT-FLOWERING CLIMBING. Mixed colors.

Pkt., 10c; oz., 15c; 1/4 lb., 50c; lb., \$1.50.

NASTURTIUM, TRAILING "TOM POUCE"

The vines grow only two feet long. Flowers small, but borne in profusion: colors, yellow, scarlet, orange and blotched. Peculiarly adapted as trailers for vases, window boxes, hanging 


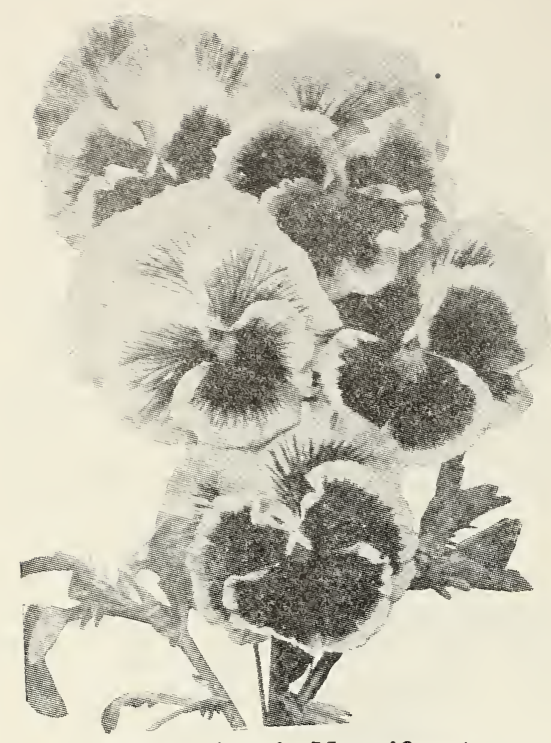

Pansy, Arno's Magnificent.

\section{MIMULUS}

Showy, profuse flowering plants; fine for greenhouse or moist shady situations; half-hardy perennials, blooming the first year from seed. 1 foot. TIGRINUS (Monkey Flower). Fine mixed spotted varieties. Pkt., 15c; 2 pkts., 25c.

\section{MOMORDICA}

Very curious climbing vine, with ornamental foliage, fruit golden yellow.

BALSAMINA (Balsam Apple). Round appleshaped fruit, very fine glossy green foliage. Pkt., 10c; $1 / 4$ oz., 25c.

CHARANTIA (Balsam Pear). Pear-shaped fruit; foliage heavier than the above. Pkt., 10c; 1/4 oz., 25 c.

\section{MYOSOTIS-FORGET- ME-NOT}

Beautiful, half hardy perennials, blooming the first year from seed; succeeding best in moist, shady situations. Sown in the Spring they will flower in the Fall.

ALPESTRIS VICTORIA. Of bushy habit; bearing large bright blue flowers ; very fine; 6 inches. Pkt., 15c; 2 pkts., 25c.

\section{NICOTIANA \\ (FLOWERING TOBACCO)}

Extremely showy annual plants, giving a continuous display of brilliant flowers through the Summer and Autumn. 2 to 3 feet.

AFFINIS HYBRIDA. Large, sweet-scented flowers; colors range through creamy white and rose tints to bright red and crimson. Pkt., 10c; $1 / 4$ oz., $30 \mathrm{c}$.

\section{NIGELLA-LOVE-IN-A- MIST}

Lovely garden annuals, with finely cut green foliage, and curious looking flowers and seed pods. MISS JEKYLL. A lovely variety, with long stems, and bearing a profusion of beautiful double flowers of a clear cornflower blue; excellent for cutting. 18 inches. Pkt., 10c; $1 / 4$ Oz., 25c.
WILLIAMS' MAMMOTH PANSIES

\section{BLOOM ALL THE YEAR ROUND} IN THE SOUTH

Pansies thrive best in a cool, moist but welldrained soil, enriched with well-rotted barnyard manure or fine-ground bone. Seeds sown in Spring in a partially shaded situation will produce fine plants for Autumn flowering. The finest blooms are to be obtained, however, by sowing in July or August, giving the plans protection during Winter, when they will bloom profusely in the Spring and Summer.

ARNO'S MAGNIFICENT. A remarkably showy class with large frilled blooms and a great variety of rich colors. Pkt., 25c.

GIANT EARLY-FLOWERING PANSIES (World Record)

This remarkable new race of Pansies flowers fully six weeks earlier than the other varieties. We recommend them highly for winter blooming and early Spring bedding. The flowers are of immense size, on long stems.

SPLENDID MIXED. Pkt., 20c; 3 pkts., 50c.

MAMMOTH BUTTERFLY. The efforts of years of scientific culture in raising Pansies have gradually evolved a superior race of luxuriant, robust growth and deep-rooting, drought-withstanding qualities; the flowers have also correspondingly improved in size, substance, form and colors. Pkt., 25c; $1 / 8$ oz., $\$ 1.00$.

RAINBOW MIXED. All colors. Pkt., 10c; 1/4 oz., 75c; oz., \$2.50.

\section{GIANT TRIMARDEAU VARIETIES}

A very showy class of vigorous compact growth, flowers of an enormous size; finest strain.

ADONIS. Light blue, with white center. Pkt., $15 \mathrm{c} ; 1 / 4$ oz., $\$ 1.00$.

DARK BLUE. A fine dark blue. Pkt., 15c; 1/4 oz., $\$ 1.00$.

FIRE KING. Red with black blotches. Pkt., 15c; $1 / 4$ oz., $\$ 1.00$.

GOLDEN QUEEN. Pure Yellow. Pkt., 15c; 1/4 oz., $\$ 1.00$.

SNOWFLAKE. Pure snow-white. Pkt., 15c; 1/4 oz., $\$ 1.00$.

TRIMARDEAU FINEST MIXED. Enormous flowers in various colors and shades. Pkt., 15c: $1 / 4$ oz., 75c.

\section{PENTSTEMON-BEARD TONGUE}

A beautiful perennial plant producing freely large spikes of handsome tubular flowers in almost every shade and color.

NEW HYBRIDS, Mixed. Produces large spikes of handsome flowers. 3 feet. Pkt., 15c; 2 pkts., 25c.

\section{PHLOX DRUMMONDI}

One of our finest hardy annuals, and should occupy a prominent place in every garden; for bedding or massing nothing can surpass them for their brilliancy and richness of color.

CECILY MIXED. The plants grow very symmetrical, in neat little bushes, 6 to 8 inches high, and are covered with flowers during the whole Summer and Fall. Pkt., 15c; 2 pkts., 25c. GRANDIFLORA VARIETIES

An improved strain with large heads of bloom, as well as large individual flowers. 12 to 15 inches.

ALBA. Pure white. Pkt., 10c; 3 pkts., 25 c.

COCCINEA. B'rilliant scarlet. Pkt., 10c; 3 pkts., 25c.

PINK. Pkt., 10c; 3 pkts., 25c.

CHOICE MIXED. All colors. Pkt., 10c; 1/4 oz., 60c.

DECUSSATA. Hardy perennial. One of the finest perennials. Extremely large heads of the most magnificent colors; blooms in August and September. 2 to 3 feet. Finest mixed. Pkt., 15c. 


\section{PETUNIAS}

For outdoor decoration, porch or window boxes few plants equal the Petunia in effectiveness. The single bedding kinds can be sown out-of-doors in May.

IAGE-FLOWERING SINGLE SORTS

SUPERB LARGE-FLOWERING FRINGED. Deepthroated and of varied and brilliant colors, and beautifully fringed. Pkt., $25 \mathrm{c}$.

LARGE-FLOWERING DOUBLE SORTS

In growing Double Petunias from seed the weaker seedlings should be carefully saved, as these usually produce the finest double flowers.

SUPERB DOUBLE-FRINGED. Will produce a large percentage of double flowers of the largest fringed varieties in bright colors. Pkt., 35c.

\section{BALCONY PETUNIAS}

A splendid large and free-flowering type for window boxes, vases, hanging baskets, etc., the flowers average 3 inches across and make a very effective display over a long season.

BALCONY BLUE. Velvety indigo-blue. Pkt., 20c. BALCONY ROSE. Brilliant rose-pink; very effective. Pkt., 20c.

BALCONY WHITE. The pure white form. Pkt., $20 \mathrm{c}$.

BALCONY CRIMSON. Rich velvety crimson. Pkt., 20c.

BALCONY MIXED. Pkt., 15c; 2 pkts., $25 \mathrm{c}$ SINGLE BEDDING PETUNIAS

All of the following are wonderfully effective in veds, borders, window boxes, etc.

SNOWBALL. Pure satiny white. Pkt., 15c; 2 pkts., $25 \mathrm{c}$.

VIOLET QUEEN. Rich velvety violet-blue. Pkt., $15 \mathrm{c}: 2$ pkts., $25 \mathrm{c}$.

ROSE OF HEAVEN. A very effective rich and brilliant rose colored variety. Pkt., 15c; 2 pkts., $25 \mathrm{c}$.

ROSY MORN. Soft rose-pink with white throat; very dainty. Pkt., 15̌c; 2 pkts., 25 .

FINE MIXED. Good bright colors. Pkt., 10c; 3 pkts., $25 \mathrm{c}$

\section{PHYSALIS}

(CHINESE LANTERN PLANT)

FRANCHETI. Dense bushes about 2 feet high, producing freely, bright orange-scarlet, lanternlike fruits; perennial. Pkt., 10c; 3 pkts., 25 c.

\section{PLATYCODON}

\section{(CHINESE BELLFLOWER)}

One of the best hardy perennials, bearing a profusion of large, bell-shaped flowers the whole season. Excellent for planting in borders or among shrubbery. 2 to 3 feet.

GRANDIFLORUM BLUE. Pkt., 10c; 3 pkts., $25 \mathrm{c}$. GRANDIFLORUM WHITE. Pkt., 15̌c; 2 pkts., $25 \mathrm{c}$.

\section{POLYANTHUS}

\section{(PRIMULA ELATIOR)}

Beautiful Spring-flowering hardy perennials, either for pot culture or for the garden; succeeds best in partial shade. 9 inches.

GOLD LACED. Flowers of brilliant colors, with distinct yellow edge. Pkt., 15c; 2 pkts., 25 c.

ENGLISH MIXED. All colors. Pkt., 15c; 2 pkts., $25 \mathrm{c}$.

\section{POPPIES}

One of our favorite and most popular flowers, producing during the blooming period a profusion of brilliant colors and shades. Seeds should be sown as early in the Spring as possible, where they are to remain, as they do not stand transplanting.

\section{SINGLE ANNUAL POPPIES}

SHIRLEY. An improved strain of this lovely race of Poppies varying in color from pure white and delicate pink to rosy carmine and deep crimson, in mixture. Pkt., 10c; 1 oz., 35c. AMERICAN LEGION. A greatly improved English scarlet or Flanders Poppy with very large flowers of dazzling orange-scarlet. Pkt., 10c; $1 / 4$ oz., $35 c$.
FLANDERS. Medium size bright scarlet flowers. Very showy when planted in masses. Pkt., 10c $1 / 4$ OZ., $35 \mathrm{c}$.

\section{CARNATION-FLOWERED POPPIES}

The flower of these poppies have petals like a carnation though it is larger and more globe shaped. A planting made in the fall will give an abundance of flowers several weeks before those planted in March.

AMERICAN FLAG. Large double snow-white flowers bordered with scarlet.

CHERRY RED. Bright red globe shaped flowers. MIKADO (Striped Japanese Poppy). Brilliant scarlet and white with beautiful curved petals, like a Japanese Chrystanthemum.

SALMON PINK. A gay rosy shade.

All varieties. Pkt., 10c; oz., 40c.

MIXED. All varieties mixed. Pkt., 10c; oz., 30c. PEONY-FLOWERED POPPIES

This type has large globe shaped double flowers that resemble a peony. The colors we offer are among the best though if a greater variety is wanted we recommend the mixed colors.

BRILLIANT ROSE. Bright rose.

RED. Cardinal red.

VIOLET. Deep violet blue.

WHITE. Pure white.

All varieties. Pkt., 10c; oz., 40c.

MIXED. All colors in mixture. Pkt., 10c; oz., $30 \mathrm{c}$.

DOUBLE SHIRLEY. A very pretty strain with double flowers in the same wonderful range of colors as the single Shirley; 30 inches. $1 / 4$ oz. 30 c.

\section{PERENNIAL VARIETIES}

For permanent beds these brilliant hardy Poppies stand unrivaled for general effectiveness and brilliancy of display.

GIANT SCARLET (Bracteatum). Large flowers. 3 feet. Pkt., 10c; 3 pkts., 25 c.

ICELAND (Nudicaule), WHITE. The satin-like flowers are borne in endless profusion and are excellent for cutting. 12 inches. Pkt., 15c; 2 pkts., $25 \mathrm{c}$.

ICELAND, ORANGE - SCARLET, Pkt., 15̄c; 2 pkts., $25 \mathrm{c}$.

ICELAND, YELLOW. Pkt., 15c; 2 pkts., $25 \mathrm{c}$.

ICELAND SINGLE MIXED. Colors range from white and yellow to deep orange-scarlet. Pkt., $10 \mathrm{c}$.

ORIENTALE. Extra large flowers; deep scarlet. Pkt., 15c; 2 pkts., 25c.

ORIENTALE, MRS. PERRY. Rich salmon-pink. Pkt., 15c; 2 pkts., 25c.

ORIENTALE HYBRIDS. Mixed. Pkt., 15̄; 2 pkts., $25 \mathrm{c}$.

\section{PORTULACA-SUN PLANT}

Brilliant hardy annual, of easy culture; excellent for massing in beds, edging or rock work, thriving best in a light, sandy soil and a sunny situation; flowers of the brightest colors.

DOUBLE MIXED. All colors. Pkt., 10c; 1/s oz., $50 \mathrm{c}$.

SINGLE MIXED. All colors. Pkt., 10c; 1/1 oz. $35 \mathrm{c}$.

\section{PRIMULA}

\section{GIANT FRINGED CHINESE}

Chinese Primroses are among our finest Winter and Spring blooming pot plants; of healthy, sturdy growth. 8 to 12 inches high, and free from insects; while they produce for weeks large trusses of flowers, which, in our new giant varieties, average $4 \frac{1}{2}$ to 6 inches in circumference.

GIANT DOUBLE. Mixed colors. Pkt., 50c.

GIANT SINGLE. Mixed colors. Pkt., $25 \mathrm{c}$.

OBCONICA GIGANTEA. These "Everflowering Primroses" are favorite pot plants for house and conservatory. Pkt., 25c.

VULGARIS (Hardy English Primrose). This is one of the best early Spring-blooming plants. Canary yellow flowers, fragrant. Pkt., 15c; 2 pkts., $25 \mathrm{c}$. 


\section{PYRETHRUM}

Handsome hardy perennial plants for the herbaceous border; flowers showy and excellent for cutting.

ROSEUM. Flowers bright rose color. July. 2 feet. Pkt., 15c; 2 pkts., 25c.

HYBRIDUM SINGLE MIXED. Large flowers ranging in color from light pink to deep red, with bright yellow centers. July. 2 feet. Pkt., 10c; 3 pkts., 25 c.

\section{RHODANTHE}

(EVERLASTING FLOWER)

For Winter bouquets the blossoms should be gathered before fully expanded, and if dried in the shade will retain their brilliancy for years. Everlasting rose and white mixed. Pkt., 10c; 3 pkts., $25 \mathrm{c}$.

\section{RICINUS-CASTOR OIL}

\section{BEAN}

This has large leaves and a tropical appearance.

ZANZIBARENSIS. Mixed. A very large-leaved variety, deep green and bronze growing 10 to 15 feet high. Plt., 10c; 0z., 25c.

\section{RUDBECKIA- CONEFLOWER}

NEWMANNI. Large yellow flowers with black center; perennial; very showy. 3 feet. Pkt., 15c; 2 pkts., 25 c.

\section{SALPIGLOSSIS- PAINTED TONGUE}

These are one of the very finest annuals, and re of the easiest culture, succeeding in any good ordinary soil and in a sunny position. The plants grow from 24 to 30 inches high, and produce freely from midsummer until frost.

CHOICE MIXED. All colors. Pkt., 10c; 3 pkts., 25c.

\section{SALVIA}

One of our most handsome Summer and Autumn flowering plants, growing into compact bushes about 3 feet high and literally ablaze with brilliant flowers; very effective for massing on the lawn and for garden decorations.

BONFIRE (Clara Bedman). Compact bushy plants, 2 feet high, producing innumerable erect spikes of the most brilliant scarlet flowers. Pkt., $15 \mathrm{c} ; 1 / 4$ oz., $90 \mathrm{c}$.

PATENS. Bright blue flowers of large size; excellent for the border or greenhouse. Height 2 feet. Pkt., 20c.

SPLENDENS. The old favorite bedding variety: tall growing plants with bright scarlet flowers; height 3 feet. Pkt., 10c; 3 pkts., 25 c.

\section{SCABIOSA-MOURNING BRIDE}

Quite hardy plants, flowering freely in cool locations all during the Summer and Fall. The well rounded, double flowers are borne on tall, slender stems nearly 2 feet in length. Easily grown and very showy.

DOUBLE RED. Plt., 10c; 1/4 oz., 35c.

DOUBLE WHITE. Pkt., 10c; 1/4 oz., 35c.

DOUBLE ROSE. Plt., 10c; 1// oz., 35c.

DOUBLE SKY-BLUE. Pkt., 10c; 1/4 oz., 35c.

LARGE-FLOWERED DOUBLE MIXED. This is

a complete mixture of all the finest colors. Of

tall growth and very free flowering. Plt., 10c; $1 / 4$ oz., 30c.

\section{HARDY PERENNIAL VARIETIES}

CAUCASICA (Blue Bonnet). One of the handsomest of hardy perennials. It is especially valuable for cutting, the lilac-blue blooms lasting a long time in water. 3 feet. Pkt., 20 c.
SCARLET RUNNER

BEANS

A great favorite in England and Europe, not only as an ornamental climber, but for the delicious edible beans which succeed the sprays of bright scarlet, pea-shaped blossoms. Pkt., 10c: $1 / 4$ lb., 20c.

\section{SCHIZANTHUS}

\section{(BUTTERFLY OR FRINGE FLOWER)}

Hardy annuals, growing $11 / 2$ to 2 feet high, and covered with bright, showy butterfly-like blossoms. WISETONENSIS. Remarkably free-flowering and presents a beautiful appearance with its myriads of blooms, the ground color of which is white, dotted with delicate rose. Pkt., 10c; 3 pkts., 25c.

\section{SHASTA DAISY}

Produces, when well grown, magnificent pure white flowers 4 inches or more across, on stems $11 / 2$ to 2 feet in length. The plants, 2 to $2 \frac{1}{2}$ feet in height, are hardy and flower in profusion. Pkt. $10 \mathrm{c} ; 3$ pkts., $25 \mathrm{c}$.

\section{STATICE- SEA LAVENDER}

Splendid hardy perennials, either for the border or rockery, producing all Summer, panicles of minute flowers, which can be dried and used for Winter bouquets.

MIXED. Containing many sorts. Pkt., 10c; 3 pkts., 25 c.

\section{TEN WEEKS STOCKS}

The plants of the large-flowering Ten Weeks Stocks make a bushy growth from 15 to 18 inches tall. They are suitable for borders, florists' designs, or for pot. culture. The sweet scented, double flowers are borne profusely on strong. stocky spikes.

BLOOD RED. Deep scarlet. Pkt., 10c.

BRILLIANT BLUE. Large bright deep blue flowers. Pkt., 10c.

BRIGHT PINK. A fine, rich pink color. Pkt., 10c.

CANARY-YELLOW. Bright canary-yellow, borne in the greatest profusion on fine stems. Pkt. 10c.

TEN WEEKS MIXED. Comprises the above five showy varieties and a few other fine colors belonging to this popular class of annual Stocks. Pkt., 10c; 1/4 oz., 75c.

"CUT-AND-COME-AGAIN" STOCKS MIXED. The branching plants, about 2 feet high, produce continuously from Summer to Fall, double flowers, splendid for cutting. Pkt., 10c; 3 pkts., 25 c.

\section{STOKESIA}

\section{(CORNFLOWER OR STOKES' ASTER)}

Plants grow about 18 to 24 inches high, bearing freely from July to October, handsome Centaurealike blossoms, each measuring from 4 to 5 inches across.

CYANEA. Lavender-blue. Pkt., 10c; 3 pkts., $25 c$.

\section{SUNFLOWER- HELIANTHUS}

Well known hardy annuals, the small flowering sorts being useful for cutting; the tall varieties are valuable for backgrounds.

MINIATURE SUNFLOWER. The compact plant are covered with small, single flowers of bright orange color. 3 feet. Pkt., 10c; $1 / 4$ oz., 20c.

NEW RED. Extra large flowers, some of which are rich chestnut-red, others tipped with yellow. 5 feet. Plt., 10c; $1 / 4$ oz., 20c.

RUSSIAN MAMMOTH. Immense single yellow flowers on tall, heavy stalks. 6 feet. Pkt., 10c; oz., 15e. 


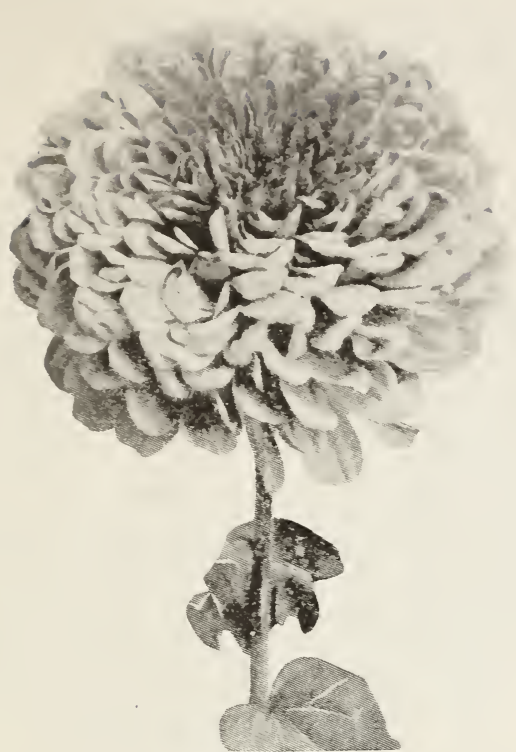

Zinnia, Dahlia Flowered.

\section{ZINNIAS}

The well known bushlike plants of Zinnias produce a profusion of large, double, imbricated flowers, borne on stiff stems. They are much used for bedding and are suitable for borders and for forcing. Few flowers are more easily grown or bloom more abundantly throughout the season, and the wide range of color is not less remarkable than their unusual depth and richness. Sow the seed early in Spring, in open ground in good rich soil, preferably in rows one and one-half feet apart and covering about one-fourth inch deep. When the young plants are one to two inches high, thin to six inches apart. Start under glass for earlier blooming. Half hardy annual; tall growing, usually about one and one-half to two feet high.

\section{GIANT DOUBLE DAHLIA-FLOWERED}

The plant is striking and spectacular in appearance and distinctly bespeaks its vigor and sturdy growth, which reaches a height of from 3 to 4 feet. The large, magnificent blooms that greatly resemble Decorative Dahlias and average from 4 to 5 inches across are borne on strong stems, clear of foliage, which make them very desirable for cut flowers as well as garden decoration.

CANARY BIRD. A very fine variety, with large flowers of a bright primrose-yellow shade. The blooms are well formed, fully double, and extremely large. They hold their color well until they have passed their prime. Pkt., $25 \mathrm{c}$; 1/4 0z., $\$ 1.00$.

CRIMSON MONARCH. One of the best of the Dahlia-flowered Zinnias, with flowers of immense size. They are a bright and attractive shade of crimson-scarlet. The blooms are of perfect form and are borne in great profusion on strong plants. Pkt., $25 \mathrm{c} ; 1 / 4 \mathrm{0z}$., $\$ 1.00$.

DREAM. A fine deep lavender turning to purple. Pkt., 25c; 1/4 oz., $\$ 1.00$.

EXQUISITE. The flowers resemble an exquisite, large, Decorative Dahlia. The color is a most showy and pleasing shade of rich rose with deeper rose in the center. The flowers are of true dahlia form, perfectly symmetrical, and of gigantic size. Pkt., 25c; 1/4 0z., \$1.00.

OLD ROSE. The flowers are a lovely shade of real old rose-a color that is most popular. A magnificent flower of extreme size. Pkt., 25c ; $1 / 4$ oz., $\$ 1.00$.
ORIOLE. A bright glistening orange shaded with iquid gold. As the flowers age they show a rich coppery cast. Pkt., 25c; $1 / 4$ oz., $\$ 1.00$.

POLAR BEAR. This is decidedly the best of all white Zinnias. The flowers are of great size, composed of many small petals. Pkt., 25c; 1/4 oz., $\$ 1.00$.

SCARIET FLAME The flowers in bright sunlight appear like flames of fire. Closer examination will show that they are a rich orangescarlet of dazzling brightness. Large and massize. Pkt., 25c; 1/4 oz., \$1.00.

DAHLIA-FLOWERED ZINNIAS MIXED. This is a complete mixture of the Dahlia-flowered Zinnias described on this page, and some fine colors not yet introduced. Pkt., 25c; 1/4 oz., 90c. PRIDE OF NORFOLK

SPECIAL STRAIN OF GIANT DOUBLE ZINNIAS

A special strain of this grand old favorite, free and continuous flowering annual, which produces flowers of colossal size, specimens measuring from 5 to 6 inches across.

LEMON QUEEN. Primrose or canary yellow. Pkt., 15c.

MISS WILLMOTT. Soft pink. Pkt., 15c.

ORANGE KING. Rich golden orange. Pkt., $15 \mathrm{c}$. PURITY. Pure white. Pkt., 15c.

ROSE QUEEN. Rich deep rose. Pkt., $15 \mathrm{c}$.

SCARLET. Deep crimson-scarlet. Pkt., 15c.

GIANT MIXED. All colors. Pkt., 15c; 1/4 oz., 75e.

IMPROVED LARGE-FLOWERING DWARF DOUBLE ZINNIAS

This we consider the best Zinnia for bedding, forming bushy, compact plants not over 2 feet high, and bearing large, perfect double flowers in good clear, distinct colors.

FINEST MIXED. Pkt., 10c; 1/4 oz., 50c.

SWEET WILLIAM-

\section{DIANTHUSBARBATUS}

Old-fashioned plants, produce large heads of beautifully colored, sweet-scented flowers in great abundance. Hardy biennial. 18 inches.

SINGLE CRIMSON. Pkt., 10c.

SINGLE PINK BEAUTY. Pkt., 15c.

SINGLE SCARLET BEAUTY. Plit., 15c.

SINGLE WHITE. Pkt., 10c.

DOUBLE WHITE, CRIMSON, and ROSE. Pkt. $10 \mathrm{c}$.

DOUBLE MIXED. All colors. Pkt., 10c; $1 / 2$ oz., $40 \mathrm{c}$.

NEW ANNUAL. This flowers continuously from early Summer from Spring-sown seed. The plants are of the same habit as the perennial kinds. In mixed colors only. Pkt., 10c; 3 pkts.. $25 \mathrm{c}$.

\section{VERBENA}

For beds, borders, mounds, vases, window boxes Hardy annual. 18 inches.

GIANT BLUE, PINK, WHITE and SCARLET. Each, pkt., 10c; 1/4 0z., 50c.

CHOICE MIXED. All colors. Pkt., 10c; $1 / 1$ oz. $35 c$.

\section{VIOLA CORNUTA}

These resemble Pansies in shape and form, with the additional quality that they are of long stems, and appear uninterruptedly from early Spring till snow.

WHITE. Pure white. Pkt., 10c.

MIXED. All colors. Pkt., 10c; 3 pkts., $25 \mathrm{c}$.

\section{WALLFLOWER}

The sweet-scented flowers are most beautiful for beds, borders, and also for cutting. Raised in pots they will bloom freely and can be taken into the house when Fall frosts are expected.

SINGLE MIXED. Pkt., 10c: 1/4 oz, 30c.

FINE DOUBLE MIXED. The spikes are closely set with double flowers of many shades, including chocolate-brown, orange, purple, crimson, bright red, etc. Pkt., 15c; 2 pkts., $25 \mathrm{c}$.

WINTER-BLOOMING WALLFLOWER (Cheiranthus kewensis). A beautiful yellow, gradually changing to orange or purple-violet. $\mathrm{Pkt} ., 15 \mathrm{c}$ 2 plits., 25c. 


\section{WILLIAMS' CHOICE ORCHID.FLOWERING SWEET PEAS}

THE BEST VARIETIES FOR GENERAL CULTURE

NOTE. We now offer only these fine Giant Spencer or Orchid-flowering Sweet Peas as they are vastly superior to the old-fashioned Grandiflora type.

PRICES : All varieties of Giant Waved Spencer Sweet Peas, except where noted, pkt., 10c; oz., $30 \mathrm{c} ; 1 / 4 \mathrm{lb}$., $90 \mathrm{c}$.

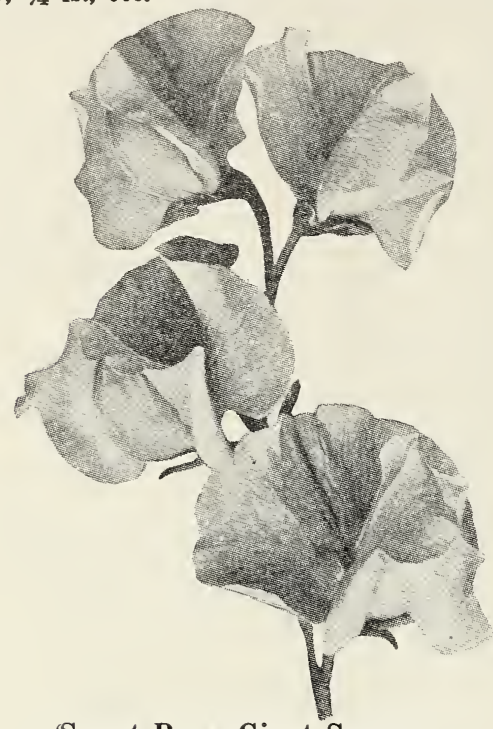

Sweet Peas, Giant Spencer.

\section{BLUE}

COMMANDER GODSALL. The color is an attractive shade of deep violet-blue. The flowers are large, of heavy substance, and attractively waved and fluted.

MRS. TOM JONES. Bright delphinium blue with large flowers on long stems.

ROYAL PURPLE. This has been for years the leading purple Sweet Pea. It is a warm, rich shade of rosy purple. The standard has a rich metallic sheen which greatly adds to the attractiveness.

\section{LAVENDER}

AUSTIN FREDERICK IMPROVED. A flower of immense size. The color is a pleasing shade of bright lavender.

POWERSCOURT. A pure lavender variety with flowers of mammoth size yet refined and well placed on long stems. We recommend this as one of the best.

\section{ORANGE}

GEORGE SHAWYER. The standard is a fine shade of bright orange-salmon, and the wings are tinted rose. The general effect is orangepink.

TANGERINE. A glowing shade of orange that makes it one of our most popular varieties.

\section{PINK}

BARBARA. This is an outstanding variety which never fails to attract attention. The blooms are a glistening shade of pure salmon. Gives a charming bunch effect.

DAISYBUD. Truly a lovely Sweet Pea, combining harmonious shades of apple blossom tints with an elusive suffusion of cream-pink. The blooms are large, well rounded, waved and frilled. A strong, sturdy bloomer.

ELEANOR WILLIAMS. One of the largest and most exquisite light rose flowers of late introduction. Plt., 15c; oz., 45e.

HAWLMARK SALMON-PINK. Rich deep pink, attractively tinted with salmon and orange. Flowers of large size and exquisite form.

ASK FOR A COPY OF OUR LEAFLET ON
MARY PICKFORD. Very large, combining extreme size with exquisite texture. Dainty and appealing cream-pink with a soft suffusion of salmon. Blooms very profusely. Pkt., 15c; oz., $45 \mathrm{c}$.

MISS CALIFORNIA. This exquisite California novelty is a charming iridescent tone of creampink with a salmon and orange hue. The flowers are large and well formed. Pkt., 15c; oz., 35c.

SUNSET. A beautiful shade of soft rich rose with a distinct halo of luminous yellow towards the base of the standard and wings. An artistic flower.

\section{RED}

CAMPFIRE. The brightest scarlet sun-proof of all the Spencers. It is the last word in vivid color. The flowers are of fine size and borne on plants of great vigor.

FIERY CROSS IMPROVED. The standard is a scorching deep cherry-red with an orange suffusion. The wings are rich cherry-orange. Most beautiful.

KING EDWARD SPENCER. One of the most popular of the Spencers. The flowers are of enormous size and waved and crinkled to a pronounced degree. The color is a beautiful, rich red.

ROYAL SCOT. A popular Sweet Pea with brilliant and lustrous orange-scarlet flowers with a deep cerise sheen. Large, well waved, of good proportions.

\section{WHITE}

DAFFODIL. An exquisite variety with frilled and waved rich cream blooms.

EDNA MAY IMPROVED. A large white flower of unusually fine form.

KING WHITE IMPROVED. Remarkable for the glistening purity of its whiteness and perfect finish of its mammoth flowers.

GIANT SPENCER AND ORCHID-FLOWERING MIXTURE. In our Giant Spencer and Orchidflowering Mixture of Sweet Peas, we are offering the choicest assortment of varieties obtainable. Beautifully waved and fluted with long stems, from 8 to 17 inches in length. Pkt., 10c; oz., $25 \mathrm{c}$; $1 / 4$ lb., $75 \mathrm{c}$; lb., $\$ 2.50$, postpaid.

\section{EARLY OR WINTER-FLOWERING SPENCER SWEET PEAS}

While these are especially adapted for forcing under glass for Winter and early Spring blooming, they are also valuable for outdoor culture, coming into bloom five or six weeks earlier than the regular Spencer or Orchid-flowered type, and if the flowers are kept cut, they will continue to bloom for a long time, producing immense, waved flowers, "fours" predominating, on long stems.

PRICES: All varieties of Early or Winter-

flowering Spencer Sweet Peas. Pkt., 20c; oz., 75c

$1 / 4$ lb., $\$ 2.50$.

AMETHYST. An early-flowering royal purple.

AVIATOR. Dazzling crimson scarlet.

CREAM. Rich deep cream.

FAIR MAID. The best blush-pink early variety. FLAMINGO. The broad and well waved standard is light orange with a suffusion of bright salmon.

GLITTERS. The standard is a bright fiery orange and the wings are deep orange.

LAVENDER KING. Large flowers of deep lavender.

MADONNA. Best giant white; black-seeded.

TRUE BLUE. A shade of true blue that is much in demand.

YARRAWA. Bright rose-pink on clear cream. Large, well waved and free blooming.

ZVOLANEK'S ROSE. One of the best in the deep pink class.

EARLY-FLOWERING SPENCERS MIXED. A choice mixture of named Early-flowering Spencer varieties. Pkt., 15c; oz., 60c; 1/4 lb., \$2.25.

WEET PEA CULTURE," TO BE INCLUDED, 


\section{WILLIAMS' CHOICE GLADIOLAS}

CULTURE. Gladiolus bulbs do best in loose, friabie soil to which a little well-rotted manure has been added. When planted for mass effect the bulbs should be from 2 to 4 inches deep and about 4 inches apart, and when in rows for cultivation the rows should be about 18 inches apart and the bulbs 4 inches apart in the row. A succession of bloom can be had by planting at different times in the Spring. They should have plenty of water just as they start to bloom as this will increase the size of the flowers. In cutting for the house it is best to cut the spike when 1 or 2 buds have opened. The remainder will open in the house.

AMERICA. Immense flowers of exquisite soft pink, glistening in the sunlight as if sprinkled with diamond dust. Strong grower, free bloomer, tall, well furnished spike. Each, 7c; doz., 70c; per $100, \$ 4.50$.

BARON HULOT. Fine deep violet-blue, full round flowers closely set on strong stem. Each, 10c; doz., $\$ 1.00$; per $100, \$ 7.00$.

CRIMSON GLOW. A perfect scarlet of a deep tone. Very large open flowers of the finest form and exceedingly well placed on a tall spike. Each, 10c; doz., $\$ 1.00$; per 100, $\$ 7.00$.

EMPRESS OF INDIA. Deep purplish red, very rare color. Each, $10 \mathrm{c}$; doz., $\$ 1.00$; per 100 , $\$ 7.00$.

EVELYN KIRTLAND. Large flowers of wonderful substance of rosy pink at the edges passing to shell-pink in the throat, with fiery scarlet blotches on lower petals. A strong robust grower. Each, 10c; doz., $\$ 1.00$; per $100, \$ 7.00$.

HALLEY. Magnificent flowers of delicate salmonpink with creamy blotch. One of the earliest. Each, $8 c$; doz., $85 \mathrm{c}$; per $100, \$ 5.50$.

LILY WHITE. Very good early pure white. Each, 8c; doz., 85c; per 100, $\$ 5.50$.

MRS. DR. NORTON. Pure soft white with tips of petals suffused La France pink. Light yellow throat. Wonderful variety. Each, 10c; doz., $\$ 1.00$; per $100, \$ 7.00$.

MRS. FRANCIS KING. Light scarlet, long strong spike bearing immense flowers. Each, 8c; doz., $85 \mathrm{c}$; per $100, \$ 5.00$.
NIAGARA. Lovely cream shade, petals canary yellow, throat carmine. Each, 9c; doz., 90c; per $100, \$ 6.00$.

MRS. FRANK PENDLETON. Very large flowers, salmon-pink with deep carmine throat. Each, $10 \mathrm{c}$; doz., $\$ 1.00$; per $100, \$ 7.00$.

PANAMA. Extra fine pink, long spikes with large flowers. Each, 8c; doz., 85c; per 100, $\$ 5.50$.

PEACE. Immense flowers of beautiful white with pale lilac feathering. Each, 8c; doz., 75c; per $100, \$ 5.00$

PRINCE OF WALES. Exquisite pure golden salmon melting to primrose, yellow throat, overlaid with deep orange. Very early. Each, 10c; doz., $\$ 1.00$; per $100, \$ 7.00$.

SCHWABEN. Clear canary-yellow, little red stripe on lower petals. Large flowers on long stalks. Each, 10c; doz., $\$ 1.00$; per $100, \$ 7.00$.

SULPHUR KING. Clear sulphur-yellow, a most valuable sort, flowers of large size. The best of the yellows. Each, 15c; doz., $\$ 1.50$; per 100, $\$ 10.00$.

VIRGINIA. Its beautiful color resembles a good dark Premier rose, being a rich scarlet. The flowers are well formed on the stem, making it an exceptional sort. Each, 15c; doz., \$1.50; $100, \$ 10.00$.

WAR. Deep blood red, shaded crimson-black, very tall, large flowering. Each, 15c; doz., $\$ 1.50$; per $100, \$ 10.00$.

WILLIAMS' RAINBOW MIXTURE. All colors. Doz., 60c; per $100, \$ 4.00$.

\section{LARGE FLOWERING CANNAS}

\section{(Dormant Roots)}

CULTURE. The ground should be spaded at least ten inches deep and well rotted manure worked in. If this cannot be obtained, sheep manure is a good substitute. The roots should be planted at least two inches below the surface and set eighteen inches to two feet apart when used in masses, and further when put in rows. Cannas love water and when the ground is dry when they are in bloom, it will repay one to keep them moist.

Planting may begin by the middle or last of March, but if early blooms are desired they can be started in pots under protection, transplanting them to open ground when danger of frost has passed. Unless they are taken up before freezing weather, they should be well covered with litter.

EUREKA. Green foliage. $4 \frac{1}{2}$ feet. The best white Canna for all purposes. The large substantial flowers are very freely produced on strong vigorous plants. 20c each; doz., \$2.00.

FIERY CROSS (Burpee's Genuine). Green foliage. The flower heads are 15 to 18 inches in length and carry from 15 to 20 open flowers of a vivid scarlet. The foliage is a beautiful lustrous blue-green. Flowers continuously from the latter part of June until frost. The foliage grows to a height of 4 to $4 \frac{1}{2}$ feet. $25 \mathrm{c}$ each; $\$ 2.50$ per doz.

KING HUMBERT. Bronze foliage. A king among cannas, because of its majestic growth; the plants are crowned with immense heads of coppery scarlet flowers. $4 \frac{1}{2}$ feet. 15c each; $\$ 1.50$ per doz.

META WILLIAMS (New). Green foliage. $4 \frac{1}{2}$ feet. A wonderful variety introduced by us. The formation of the flower resembles an orchid and the color is a canary yellow with blotches, streaks and spots of terra cotta. A bed of this Irom a distance gives a most wenderful effect. 36e each; $\$ 3.00$ per doz.

MRS. ALFRED F. CONARD. Green foliage: 4 feet. The gigantic flowers which are borne in immense clusters, are of delightful salmon-pink, a shade which becomes more brilliant as the fonter develops. 20c each; $\$ 2.00$ per doz.
PANAMA. Green foliage. 3 feet. Color rich orange-red with a border of golden yellow. Flowers of large size with enormous wide petals. $15 \mathrm{c}$ each; $\$ 1.50$ per doz.

ROSEA GIGANTEA. Green foliage. 31/2 feet. Rich soft rose-pink flowers of gigantic size; a prolific bloomer. The large broad petals and the massive heads of bloom invariably create a sensation. 15c each; $\$ 1.50$ per doz.

THE PRESIDENT. Green foliage. 4 feet. This Canna is superior to any other red variety in quality and also quantity of bloom. Color rich glowing scarlet and the immense firm flowers are produced on strong, erect stalks. 15c each; $\$ 1.50$ per doz.

YELLOW KING HUMBERT. Green foliage. 4 feet. This is a sport of the well-known bronzeleaved variety, but this sort has green foliage; about 4 feet high, with masses of golden yellow flowers, dotted red. 20c each; $\$ 2.00$ per doz.

SHENANDOAH. Bronze foliage. 4 feet. The foliage is rich ruby-red, veined and tinted bronze. It bears fine large trusses of beautiful waxy rose-pink flowers. $15 \mathrm{c}$ each; $\$ 1.50$ per doz.; $\$ 10.00$ per 100 .

WINTZER'S COLOSSAL. Green foliage. 5 feet. Without a doubt the largest-flowered Canna yet produced. Flowers of vivid scarlet, sometimes measuring eight inches across. 15c eat ; \$1.50 per doz. 


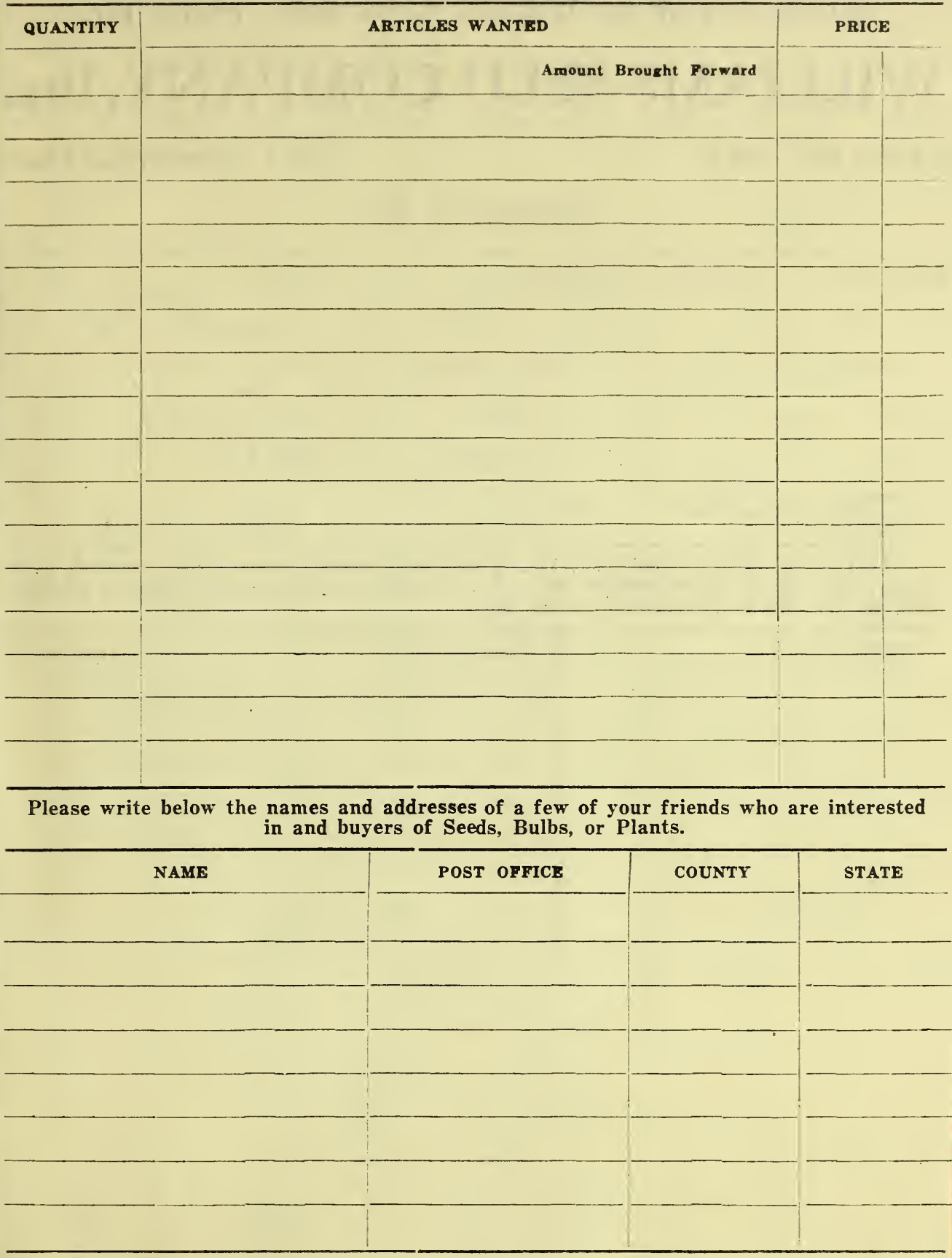

PLEASE DO NOT WRITE IN THIS SPACE

Route shipped by

Date shipped

In

Pkgs., -._._....... Bundles,

Boxes,

Crates,

Baskets,

Bbls.

Filled by

Checked by

Reply required by 
From (Name)

P. O.

R. F. D.

State.........................

WILLIAMS SEED CO, Inc. 69-71 Commercial Place

P. O. BOX 596 



\section{SUMMER FLOWERING BULBS}

Amaryllis For indoor culture the Amaryllis is one of the most beautiful, surest to flower and like flowers, six inches in diameter. Plant one bulb in a 6-inch pot, water sparingly until the flower shoots appear. They thrive best in soil composed of two-thirds good garden loam and one-third leaf mold, adding a little sand.

BELLADONNA MAJOR. Flowers are of a lovely shell-pink color and very fragrant, produced very freely on stems two feet high. Each, $40 \mathrm{c}$; doz., $\$ 4.00$, prepaid.

Begonias (Tuberous Rooted) Begonias do best if kept in the semi-shade. They If grown in pots in the house, they should be protected against the strong mid-day sun. The soil best suited to Begonias is a rich, sandy loam with a liberal addition of thoroughly rotted manure and leaf mold. Plant the bulbs in pots or pans, so that the top of the bulb is just barely visible.

SINGLE. Very large flowers, quite conspicous, producing best bedding effects. Each, 30c; doz., \$3.00; 100, \$25.00. Pink, Crimson, White, Yellow, Salmon, Orange.

DOUBLE-FLOWERING. The double flowers are similar to Camellias, usually from 2 to 3 inches in diameter. Each, 35c; doz., \$4.00; 100, \$32.00. Yellow, Orange, Crimson, Salmon, Pink, White.

Caladium Esculentum (ELEPHANT'S EAR). Very showy ornamentals, producing a used as a border around bronze-leaved Cannas. The foliage is very large, sometimes 2 feet across. Bulbs may be started in pots and planted out during May and June. Plant about 15 inches apart. 3 to 4 feet.

LARGE BULBS. Each, $20 \mathrm{c}$; doz., $\$ 2.00 ; 100, \$ 10.00$.

MAMMOTH BULBS. Each, 30c; doz., $\$ 3.00 ; 100, \$ 18.00$.

Caladium, Fancy Leaved Most desirable ornamentals for pots or window boxes, having colors and markings; handsome and striking.

CHOICE MIXED VARIETIES. Each, 35c; doz., \$3.50.

Calla Lilies-Arum ELLIOTTIANA (The Golden Calla). A new variety with rich golden during February and June. Flowers in Summer if planted in the early Spring.

MAMMOTH BULBS. Each, 50c; doz., \$5.00.

Cinnamon Vine-Chinese Yam splendid, hardy climber, rapid grower; with cinnate bright, glossy green, heart-shaped leaves. White, Convallaria (Lily-of-the-Valley) The stock we offer is in strong clumps, $50 \mathrm{c}$; doz., $\$ 5.00$.

Hardy Lilies For color, fragrance, beauty and variety of form, nothing can equal these grand their makes them so desirable.

LILIUM AURATUM (The Gold-Banded Lily of Japan). The most beautiful variety of all the Lily family. Flowers white, dotted crimson, with a clear golden band running through the center of each petal; very fragrant... Mammoth bulbs, each, $50 \mathrm{c}$; doz., $\$ 5.50$.

LILIUM SPECIOSUM RUBRUM. Large bulbs producing attractive white flowers shaded and spotted with rose and red. Mammoth bulbs, each, $60 \mathrm{c}$; doz., $\$ 6.00$.

TIGRINUM SPLENDENS (Tiger Lily). The grandest of the Tiger Lilies. Black polished stem, sometimes 6 feet high. Very large pyramids of flowers, orange-red spotted with black. 3 to 5 feet high. Blooms in August. Each, $35 \mathrm{c}$; doz., $\$ 3.50 ; 100, \$ 10.00$.

Madeira Vine Thick, glossy leaves, and long, hanging stems of feathery, fragrant white postpaid.

Peonies The Peony is affected by few plant diseases and no insect pests, and given good soil and the Fall a little attention, will bloom profusely and increase in size and beauty yearly. Plant in

EDULIS SUPERBA. Large, shaggy flat crowns, often 6 to 7 inches across. Color bright mauve-pink, with silvery reflex. More largely grown for early cut flowers than any other variety. Each, \$1.00; 3 for $\$ 2.50$; doz., $\$ 10.00$.

FELIX CROUSSE. Generally considered the best red Peony in existence. Its large, globular, compactly built flowers are a rich, even, brilliant, dazzling ruby-red, free from the objectionable violet or purple shades. Each, $\$ 1.25 ; 3$ for $\$ 3.00$; doz., $\$ 11.50$.

FESTIVA MAXIMA. It combines enormous size with wondrous beauty. Often 7 to 8 inches across. Color pure snow-white with an occasional clear carmine marking in center. Each, $\$ 1.00 ; 3$ for $\$ 2.50$; doz., $\$ 10.00$.

Peony Roots in Separate Colors EXHIBITION DOUBLE wHITE, ROSE-PINK, DOUBLE MIXED COLORS. Each, $45 \mathrm{c}$; doz., $\$ 4.50 ; 100, \$ 32.50$.

Tuberoses Summer-flowering bulbs, producing long spikes of very fragrant blossoms. Plant light soil.

DOUBLE PEARL. Pure white. First size bulbs. Each, 7c; doz., 75e (by mail 90c); $100, \$ 4.50$.

DOUBLE PEARL MAMMOTH. Extra large, selected bulbs. Each, 10c; doz., $\$ 1.00$ (by mail $\$ 1.20$ ); $100, \$ 7.00$. 


\section{INSECTICIDES, FUNGICIDES, ETC.}

\section{Prices Subject to Market Changes. Purchasers Pay Transit Charges.}

ARSENATE OF LEAD (Powdered). Does not burn foliage. Has all advantages of Arsenate of Lead Paste, but goes twice as far. Dilute 1 pound to 50 gallons. $1 / 21 \mathrm{~b} ., 35 \mathrm{c} ; 1 \mathrm{~b} ., 60 \mathrm{c}$.

BLACK LEAF 40 (Nicotine Sulphate). Most effective spray to kill all plant lice; 2 it kills by contact, it should be applied through an atomizer. Oz. bottle, $35 \mathrm{c} ; 1 / 2-1 \mathrm{~b}$. tin, $\$ 1.25 ; 2-1 \mathrm{~b}$. tin, $\$ 3.75 ; 10 \mathrm{lbs}$., $\$ 15.50$.

BORDEAUX MIXTURE (Powdered). Used same as Bordeaux Mixture Liquid. Also used for dry dusting. Dilutes 1 pound to 8 gallons of water. 1 lbs., $45 \mathrm{c} ; 5$ lbs., $\$ 2.00$.

CALCIUM, ARSENATE. (Dry). For dusting and spraying. A new arsenical poison for chewing insects, especially potato beetles. Harmless to foliage, not easily washed off. Lb., 40c; 5 lbs., \$1.25; 10 lbs., \$2.00. Write for prices in 100-lb. lots.

FUNGTROGEN. A highly concentrated form of fungicide that will conquer mildew and control black spot on roses. It also supplies an essential fertilizer. Dilutes 1 part with 60 parts of water. 1/2 pt., 75c; pt., $\$ 1.25$; qt., $\$ 2.00 ; 1 / 2$ gal., $\$ 3.50$.

KEROSENE EMULSION (Liquid) (Miscible Oil). Diluted in water this makes an excellent spray for all mild forms of scale, and soft lice of any kind such as infest rose and fruit bushes, vegetables and trees. Dilutes 1 part to 20 parts of water. Qt., 75c; gal., $\$ 1.75$.

MELROSINE. The most effective remedy for killing full-grown rose bugs. Will not discolor flowers. Dilute 1 part to 20 parts of water. Trial size, 50c; pt., $\$ 1.00 ;$ qt., $\$ 1.75 ; 1 / 2$ gal., $\$ 3.25 ; g a l ., \$ 6.00$.

PARIS GREEN. An insoluble, poisonous powder for potato bugs, codling moth, worms, caterpillars, slugs and bugs. Applied as a powder it should be mixed with plaster or flour, 100 parts to 1 part of Paris Green; in solution, mix $1 \mathrm{lb}$. in 200 to 300 gallons of water. 1/2-1b. pkg., 35c; 1-1b. pkg., 65 c; 5-lb. pkg., $\$ 2.30$.

PYROX. A combined insecticide and fungicide for all leaf-eating insects, blights and fungous troubles on trees, grapes, small fruits, potatoes, cucumbers, vegetables, roses, shrubbery, etc. It is a creamy paste, and needs only to be mixed with cold water to apply. 1-lb. bottle, 50c; 5 lbs., \$2.00.

SCALECIDE. Sure death to the San Jose scale. A soluble petroleum spray for use in orchards. It is economical, effective, and acts as a fungicide. Qt., 75c; gal., $\$ 1.75$.

8LUG SHOT. The standard remedy for current worms, rose slugs, cabbage worms, and almost any soft-shelled insects that infest the vegetable or flower garden. 1-lb. canister, 25c; 5 lbs., 60 ; 10 lbs., $\$ 1.20 ; 25$ lbs., $\$ 2.75 ; 100$ lbs., $\$ 11.00$.

DRY LIME-SULPHUR. Exactly like lime-sulphur except that the water has been taken out. For fall and spring spraying, use 12 to $15 \mathrm{lbs}$. to 50 gallons of water; stone fruits $11 / 2$ to $2 \mathrm{lbs}$. to 50 gallons of water. To the summer spray add 2 lbs. arsenate of lead to make a combined insecticide and fungicide. 1 lb., $40 \mathrm{c}$; 5 lbs., $\$ 1.50 ; 10$ lbs., $\$ 2.50$.

BULFOCIDE. A highly concentrated non-poisonous liquid sulful fungicide-entirely distinct from lime-sulfur. Within a few minutes after the spray is applied and before it is dry, Sulfocide is decomposed by the action of the air leaving a film of extremely fine sulfur in its most active fungicidal form. Qt., $\$ 1.00 ; \mathrm{gal}$., $\$ 2.75$.

TREE TANGLEFOOT (Liquid). Applied directly to the bark of trees; will catch all climbing insects. One application remains effective for three months. 1 lb., 50 c; 3 lbs., $\$ 1.45 ; 5$ lbs., $\$ 2.25$.

TOBACCO DUST. 1 lb., $15 \mathrm{c} ; 5$ lbs., 50c; 10 lbs., 75c; 100 lbs., $\$ 6.00$.

WEED KILLER. Kills all plant growth. Dilute 1 part to 60 parts of water. 1 qt., $60 \mathrm{c} ; 1 / 28 \mathrm{al} ., \$ 1.00$; 1 gal., $\$ 1.75 ; 5$ gals., $\$ 6.50$; 50-gal. barrel, $\$ 50.00$.

\section{WILLIAMS’ HIGH GRADE FERTILIZERS}

\section{Prices quoted are F. O.B. Norfolk, and subject to change without notice.}

WILLIAMS' SPECIAL GARDEN FERTILIZER. For vegetables, lawns, flowers and bulbs. 6-lb. pkg., 65c: $12-\mathrm{lb}$. pkg., $\$ 1.10 ; 25-\mathrm{lb}$. pkg., $\$ 2.00$. If wanted by parcel post add postage at zone rates.

NITRATE OF SODA. Apply 100 to $150 \mathrm{lbs}$. per acre, mixing with land plaster or other fertilizers to render application more easy. Use only after plants are above ground. If used in liquid form dilute $2 \mathrm{ozs}$. to $1 \mathrm{gal}$. of water and do not apply oftener than twice a week. 5 lbs., $45 \mathrm{c} ; 85 \mathrm{c}$ per 10 lbs.; 25 lbs., $\$ 1.50$; $\$ 2.75$ per 50 lbs.; 100 lbs., $\$ 5.25 ; \$ 10.00$ per 200 lbs.

POULTRY MANURE (Pulverized). A splendid fertilizer, rich in ammonia and nitrogen, very quick in action, but should be used cautiously. 5 lbs., $35 \mathrm{c} ; 10 \mathrm{lbs} ., 65 \mathrm{c} ; 25$ lbs., $\$ 1.00 ; 50$ lbs., $\$ 1.75 ; 100$ lbs., $\$ 3.50$.

PULVERIZED SHEEP MANURE. Sheep manure is the ideal fertilizer to use for the lawn, in the garden, the perennial border, shrubbery beds, small fruit garden, flower beds, etc. 2 lbs., 20 ; 5 lbs., $35 \mathrm{c} ; 10$ lbs., 55c; 25 lbs., $\$ 1.00 ; 100$ lbs., $\$ 3.25$.

BTIM-U-LANT. A fertilizer in tablet form. The tablets contain the essential plant foods in highly concentrated form, and are, therefore, very convenient for house use. Package of 30 tablets, 25c; 100 tablets, $75 \mathrm{c} ; 1000$ tablets, $\$ 3.50$.

BLOOD (Dried). For indoor culture of flowering plants, like roses, carnations, etc., its chief element being nitrogen. One of the quickest acting fertilizers. 5 lbs., 75c; 10 lbs., \$1.25; 25 lbs., \$2.50.

RAW GROUND BONE. This is moderately fine and particularly adapted for general fertilizing; the finer particles are immediately beneficial, the coarse keeping up the supply of plant food for a long period. 5 lbs., $40 \mathrm{c}$; $10 \mathrm{lbs} ., 75 \mathrm{c} ; 100 \mathrm{lbs}$., $\$ 4.00 ; 200 \mathrm{lbs} ., \$ 7.50$.

LAWN DRESSING (Wilsco). Specially prepared for lawns, golf courses, meadows, etc. Apply broadcast at rate of 1,000 to 1,500 lbs. to the acre. 5 lbs., $35 \mathrm{c} ; 10 \mathrm{lbs} ., 60 \mathrm{c} ; 25 \mathrm{lbs}$., $\$ 1.25 ; 50 \mathrm{lbs} ., \$ 2.00$; 100 lbs., $\$ 3.50$; ton, $\$ 50.00$.

LIME (Hydrated or Powdered). This is a very fine article for distributing on grass. Promotes growth, gives the grass a rich color and has a tendency to prevent the growth of weeds. Apply one ton per acre. $10-1 \mathrm{~b}$. bas, $45 \mathrm{c} ; 100-1 \mathrm{~b}$. sack, $\$ 2.00$. Ton prices on application.

VIGORO. Ideal plant food for regetables, flowers, lawns, etc. 5 lbs., 50c; 25 lbs. $\$ 1.75 ; 501$ lbs. $\$ 3.00$; 100 lbs., $\$ 5.00$. 